\title{
Anonim Ortaklık Pay Sahipleri Arasında Yapılan Önalım Hakkı İçeren Sözleşmeler
}

\author{
Direnç Akbay*
}

\section{Öz}

Anonim ortaklıklarda değişik gerekçelerle pay sahipleri sözleşmeleri yapılmaktadır. Bu sözleşmelerde tarafların önalım hakkına da yer verilmektedir. Çalışma, anonim ortaklık pay sahipleri arasında yapılan sözleşmelerde yer verilen önalım haklarını konu almaktadır. Bir şekilde esas sözleşmede yer alan önalım haklarının akıbeti de çalışmada değerlendirilmiştir.

Çalışmanın merkezinde önalım hakkına ilişkin olaylarda uygulanacak kuralların tespit edilmesi sorunu yer almaktadır. Bu nedenle özellikle Türk Borçlar Kanunu'nun taşınmazlara ilişkin olarak öngördüğü sözleşmesel önalım hakkı kuralları incelenmiştir. Bunların pay sahipleri sözleşmelerinde yer verilen önalım hakkına ilişkin kurallara hangi ölçüde uygulanabileceği değerlendirme konusu yapılımıştr.

Uygulamada sıklıkla karşılaşılan önalım sözleşmelerinin öngörülme nedenleri ve şekli üzerinde durulmuştur. Söz konusu sözleşmenin hukuki niteliği ve bunun etkileri değerlendirme konusu yapılmıştı. Önalım sözleşmelerinin zorunlu içeriği tespit edilmiştir. Önalım hakkını kullanmanın ön koşulu, başka bir ifadeyle önalım olayı, incelenmiş ve bunun gerçekleştiğini bildirme yükümlülüğü üzerinde durulmuştur. Ayrıca hakkın kullanılma şekli ve bunu kullanmanın ortaya çıkaracağı sorunlar çalışmada ele alınmıştır. Hakkın etkisinin taraflar arasında olduğu sonucuna ulaşılmış ve hakkın kullanımının payın devri sonucunu doğurmayacağı ifade edilmiştir. Çalışma ayrıca önalım hakkının sona ermesini gerektirecek nedenleri ve bunun etkilerini de konu almaktadır.

\section{Anahtar Kelimeler \\ Anonim ortaklık, Pay sahipleri sözleşmesi, Önalım hakkı, Türk Borçlar Kanunu, Ortaklıklar hukuku}

\section{Agreements between Shareholders of Joint Stock Companies, Which Include Right of Preemption}

\begin{abstract}
Shareholders' agreements are made in joint stock companies for various reasons. These contracts feature the right of preemption of parties. This article deals with the rights of preemption, which can be found in contracts that have been made by shareholders of joint stock companies. The consequences of preemption rights, which can be found in articles of companies, are also examined in the study.

The study focuses particularly on the problem of which rules are applicable for cases that include the right of preemption. Turkish Code of Obligations and Turkish Commercial Code have no rules for preemptive rights on shares of joint stock companies. But Turkish Code of Obligations has rules for preemptive rights on real estates. It is also taken as a subject of evaluation, to what extent these rules are applicable to the shareholders' agreements, which include right of preemption.

The reasons and the form of preemption contracts, often encountered in practice, are emphasized. The juridical quality of this contract and its reasons are also evaluated. The mandatory content of the preemption contracts are determined. The event of preemption, as a precondition in order to benefit from one's right is analyzed and the obligation of its notification is also examined. Moreover, the article also deals with the form of benefiting from one's right and problems,
\end{abstract}

\footnotetext{
Sorumlu Yazar: Direnç Akbay (Arş. Gör. Dr.), Dokuz Eylül Üniversitesi, Hukuk Fakültesi, Ticaret Hukuku Anabilim Dalı, İzmir, Türkiye. E-posta: direnc.akbay@gmail.com ORCID: 0000-0001-9925-9255

Atıf: Akbay D, “Anonim Ortaklık Pay Sahipleri Arasında Yapılan Önalım Hakkı İçeren Sözleşmeler" (2019) 77(2) İstanbul Hukuk Mecmuası 697. https://doi.org/10.26650/mecmua.2019.77.2.0008
} 
which come up because of its use. Making use of the right of preemption typically has an effect between the parties of the shareholders' agreements and it does not come up with such a result as a takeover of company shares. The article includes also the reasons, which involve end of preemption right and effects of it.

\section{Keywords}

Joint stock company, Shareholders' agreement, Right of preemption, Turkish Code of Obligations, Company law

\section{Extended Summary}

To ensure a stable or firm composition of a shareholder group in a joint stock company, the Turkish Commercial Code includes rules on restricted transferability. The restriction possibility of transferability of shares in a joint stock company is limited. Because of this, shareholders of these companies make contracts, which are so called "shareholders' agreements". In these agreements the right of preemption of parties is a dominant feature. With a contractual right of preemption of parties, it is possible to protect the composition of a shareholder group. The contractual right of preemption is basically a problem of the law of obligations, but it has effects on the side of law of companies. It can be used as an alternative to statutory restriction of transferability of shares.

The study focused especially on the issue of which rules are applicable for the cases that include the right of preemption. Thus, the rules of the Turkish Code of Obligations on preemptive rights, which are provided for immovables are investigated. Another area dealt with in this article is the extent to which these articles are applicable for the rules of shareholders' agreements, which include the right of preemption.

Contractual right of preemption, which occurs in a shareholders' agreement, is generally not subject to any form. But there could be exemptions. The agreement must be considered as a whole, if a right of preemption is created depending on the death of one of the parties. In order to solve the problem about the form of this agreement, the legal quality of the shareholders' agreement must be established. Some shareholders' agreements are qualified as a partnership under the Turkish Code of Obligations. If the right of preemption is described as a qualified successorship clause (in the partnership under the Turkish Code of Obligations), this agreement must be in the form of a disposition mortis causa. If the right of preemption is described as a simple successorship clause (in the partnership under the Turkish Code of Obligations) or if the legal quality of the shareholders' agreement isn't a partnership under the Turkish Code of Obligations, there is no need to make this contract in the form of a disposition mortis causa.

The right of preemption can be divided into two categories. One type is called the real right of preemption and basically this type of right is the theme of this article. Real right of preemption cannot be an article or a rule of a joint stock company's statute. If 
a statute of a joint stock company contains the right of preemption for shareholders, who remain in the company and against the shareholder, who wants to sell his/her shares to a third party, it must be accepted as void from the beginning. This study shares the idea that rules of statutes which include the right of preemption cannot at the same time be handled as a contractual agreement under the law of obligations between shareholders. This can be accepted under very exemptional circumstances.

The essential contents of the shareholders' agreements which contain the right of preemption are the parties of the agreement and the subject of the contract. The price of the subject is not one of them because Art 241/III in the Turkish Code of Obligations is applicable for contracts which do not include a price rule. This means that if there is a lack of rule about the price of the share in a shareholders' agreement, the price is determined according to the sales contract between the shareholder, who wants to sell his/her share and the third party, who wants to buy this share. If there is a price rule in the agreement, that creates the right of preemption, and this right of preemption is called a limited right of preemption; otherwise it is called an unlimited right of preemption.

The condition which makes the use of the right of preemption possible is called a preemptional event. The preemptional event is generally a share sales contract between one party of the shareholders' agreement and a third party. Art 240/I in the Turkish Code of Obligations about preemptional events is also applicable to the shareholders' agreements, which create contractual right of preemption between shareholders. The seller party of the share sales agreement is also obliged to give this information to the parties of the shareholders' agreements. In this study we maintain that Art 241 in the Turkish Code of Obligations is not fully applicable to the shareholders' agreements that include the right of preemption. That is why we suggest that only the seller has the obligation to give information to the parties of the shareholders' agreement, but not the buyer. Preventing the occurrence of preemptional event is also evaluated in the study, and in addition to the other legal probabilities, we suggest that the Art 175 in the Turkish Code of Obligations is also applicable for these situations.

By making use of the right of preemption, the subject of the right cannot be divided, if the shareholders' agreement has no other rules. Usually the subject of the right and the subject of the share sales agreement are the same. In the light of our study Art 242 in the Turkish Code of Obligations is partly applicable for the contractual right of preemption on shares. That means the owner of the right must make use of his/her right within three months at most. We think that a maximum duration of two years, which is also regulated in Art 242, is not applicable to the contractual right of preemption on shares. In our opinion it is a special duration for the right of preemption on immovables. 
Making use of the right of preemption typically has an effect between the parties of the shareholders' agreements and it does not come up with such a result as a takeover of company shares. Because of this, an act of a party, which violates the shareholders agreement (also their right of preemption), may give a compensation right to the other parties for their damages. The right of preemption principally has no effect on the third parties, like the party of the share sales agreement. Some exemptional situations are also evaluated in the study. 


\section{Anonim Ortaklık Pay Sahipleri Arasında Yapılan Önalım Hakkı İçeren Sözleşmeler}

\section{Giriș}

Anonim ortaklıklar sermaye unsuru merkeze alınmak suretiyle düzenlenmiştir. Ortaklığın bu özelliği, pay sahipleri açısından bazı yararları beraberinde getirmektedir. Pay sahipleri hakkında kural olarak tek borç ilkesinin geçerli olması ve diğer ortaklık türlerine kıyasla anonim ortaklık pay sahibinin zayıf bir sadakat yükümlülüğü altında bulunması sermaye unsuru merkeze alınarak yapılan düzenlemelerin birer sonucudur.

Sermaye unsurunun merkeze alınıp kurumsal bir yapının oluşturulması, az pay sahipli anonim ortaklıklar bakımından bazı sorunları da beraberinde getirir. $\mathrm{Bu}$ ortaklıklarda pay sahiplerinin şahısları da ön plandadır. Dolayısıyla anonim ortaklıklar sisteminin öngördüğü yapısal kuralların haricinde pay sahipleri arasında şahıs unsurunu esas alan sözleşmeler yapılmaktadır. Bu sözleşmelerde sıkça rastlanılan düzenlemelerden birisi de pay sahipleri arasında önalım hakkı anlaşmalarının yapılmasıdır. Konumuzu da pay sahipleri arasındaki önalım hakkı içeren sözleşmeler oluşturmaktadır.

Sözleşmesel önalım hakkının hukuki niteliği, öngörülme nedeni ve şekli gibi temel sorunlar haricinde çözümlenmesi gereken birçok sorunla karşılaşılmıştır. Yine esas sözleşmede önalım hakkına yer verilip verilemeyeceği ve buna yer verildiyse akıbetinin ne olacağı değerlendirilmiştir. Önalım hakkı içeren sözleşmelerin zorunlu unsurları ortaya konmuş ve özellikle önalım olayının gerçekleşmesi halinde ortaya çıkan durum incelenmiştir. Ayrıca hakkın kullanılması, usulü ve süresiyle kullanmanın sonuçları ve hakkın sona ermesi de değerlendirme konusu yapılmıştır.

\section{Pay Sahipleri Sözleșmelerinde Önalım Hakkına Yer Verilme Gerekçeleri}

Anonim ortaklıkların sermaye odaklı yapısı, uygulamada çoğunluğu oluşturan az ortaklı ve halka açılma planı bulunmayan anonim ortaklıkların ihtiyaçlarına yeteri kadar cevap verememektedir' ${ }^{1}$. Bu ortaklıklar pay sahipleri arası güç dengesi gözetilerek kurulmaktadır². Bu nedenle ortaklık içi güç ilişkilerinde oluşabilecek bir dengesizlik sorun olarak görülmektedir. Bu sorun uygulamada genelde pay sahipleri sözleşmeleriyle giderilmeye çalışılmaktadır³. Pay sahipleri sözleşmelerinin asıl içeriğini pay sahibinin ortak sıfatından kaynaklanan hakları ve özellikle onların konumunu doğrudan ilgilendiren düzenlemeler oluşturmaktadır. Önalım hakkı gibi

İsviçre hukukunda, anonim ortaklıkların çoğunluğunun, kanunî örnek olan, sermaye odaklı halka açı anonim ortaklık tipiyle uyumlu olmadığı yönünde bkz Markus Bösiger, 'Bedeutung und Grenzen des Aktionärbindungsvertrages bei personenbezogenen Aktiengesellschaften' (2013) (1) REPRAX 1, 1.

Şahıs unsuru ön plana çıkan çok sayıda anonim ortaklık için, pay sahiplerinin kendi aralarındaki ve onlarla ortaklık arasındaki ilişkileri düzenleyen uygun kanunî hükümler olmadığı İsviçre hukukunda vurgulanmaktadır (ibid 1, 1).

Bu bağlamda açıklamalar için bkz Markus Vischer, 'Vorkaufsrechte an Aktien' (2014) (1) GesKR 82, 82. 
devir hakkına yönelik düzenlemeler de bu kategoride kabul edilmektedir ${ }^{4}$. Bu nedenle önalım hakkının pay sahipleri sözleşmelerinin standart içeriğinden olduğu öğretide ifade edilmektedir ${ }^{5}$.

Pay sahipleri sözleşmeleriyle sözleşme tarafları, ortaklıklar hukukundan ayrı olarak birçok hususu kendi aralarında düzenleyebilmektedir. Sözleşmeler yoluyla sağlanan bu düzenin devamı, sözleşme taraflarıyla pay sahipliği arasındaki ilişkinin bozulmamasını gerektirir. Bu sözleşmelerde, önalım hakkı öngörülmesinin pay sahipleri çevresinin kontrol altında tutulmasına hizmet ettiği öğretide belirtilmektedir ${ }^{6}$. Sözleşme tarafları, devir hakkına yönelik kısıtlamalar getirerek oluşturdukları çevrenin bir arada tutulmasını sağlamaya çalışmaktadır ${ }^{7}$. Burada yapılmaya çalışılan, paya sahip olanlarla sözleşme tarafları arasında bir bağlantı kurabilmektir ${ }^{8}$. Kapalı pay sahipleri çevresi olan anonim ortaklıklarda bu düzenin korunması için, payların nama yazıl1 ${ }^{9}$ olarak öngörülmesi ve bunların bağlam kurallarına tabi tutulması tavsiye

${ }^{4}$ Bu hususta bkz Monika Hintz-Bühler, Aktionärbindungsverträge (Stämpfli 2001) 18 ve 21; Maja R Baumann, Die Familienholding (Schulthess 2016) 162.

Bkz Vischer (n 3) 82, 82.

6 Bu bağlamda bkz Damian Fischer, Änderungen im Vertragsparteienbestand von Aktionärbindungsverträgen (Dike 2009) 283; Sandro Germann, Die personalistische AG und GmbH - Unter besonderer Berücksichtigung von Aktionärund Gesellschafterbindungsverträgen (Dike 2015) 696 para 1619; Dieter Zobl, 'Die Pfandrechtliche Sicherung von Erwerbsberechtigungen in Aktionärbindungsverträgen' in Hans Caspar von der Crone and others (eds), Neuere Tendenzen im Gesellschaftsrecht Festschrift für Peter Forstmoser (Schulthess 2013) 401, 403; Baumann (n 4) 162. Hukukumuz açısından bu yönde bkz Gül Okutan Nilsson, Anonim Ortaklıklarda Paysahipleri Sözleşmeleri (Çağa Hukuk Vakfı 2004) 214.

7 Bu yönde açıklamalar için bkz Peter Forstmoser and Marcel Küchler, Aktionärbindungsverträge Rechtliche Grundlagen und Umsetzung in der Praxis (Schulthess 2015) 371 para 1170. Benzer olarak bkz Marcel Gloor and Andrea E Flury, 'Die Call Option an Aktien beim Tod eines Aktionärs' (2005) 101 (13) SJZ 305, 306. Roland Müller and Kathrin Biedermann, 'Der Aktionärbindungsvertrag als Unterstützungsmassnahme bei der Nachfolge- und Nachlassregelung' (2015) (6) AJP 885,893 'te bununla uyumlu olarak, önalım haklarının daha çok aile tipi ortaklıklarda öngörüldügünü ifade etmektedir. Böylelikle ortaklığa aileye yabancı kişilerin girmesi engellenmiş olur. Sonuncu hususta benzer olarak bkz Baumann (n 4) 162 .

8 Önalım hakları payların istenmeyen üçüncü kişiler tarafından iktisabını engelleme işlevini gösterirler [bu hususta bkz Germann (n 6) 696 para 1619]. Önceki sistemimiz bakımından hukukumuzda, "anasözleşmelere konulan paylar üzerindeki önalım haklarının amacı, payın satışı durumunda hak sahibine öncelik sağlamak, böylece payın üçüncü kişiye geçişini önlemek; arzu edilmeyen kişileri ortaklığa dâhil etmemek ve yabancılaşmayı engellemek" olarak ifade edilmiştir [bkz Mehmet Bahtiyar, 'Anonim Ortaklıkta Payların Üçüncü Kişilere Satılması Durumunda Diğer Ortaklara Önalım Hakkı Tanıyan Anasözleşme Hükümleri ve Etkileri’ (2001) 21 (2) BATIDER 83, 88]. Taşınmazlar bakımından da başkasına yapılacak bir satışı önleme amacına hukukumuzda işaret edilmiştir [bkz Murat Aydoğdu and Nalan Kahveci, Türk Borçlar Hukuku-Özel Borç İlişkileri (Sözleşmeler Hukuku) (Adalet 2017) 277; Cevdet Yavuz, Faruk Acar and Burak Özen, Türk Borçlar Hukuku Özel Hükümler (Beta 2014) 254].

9 TTK m 492, esas sözleşmesel bağlam öngörülebilmesinin koşulu olarak payların nama yazılı olmasını aramaktadır. Keza TTK m 490'ın başlığı "nama yazılı payların ve pay senetlerinin devrinde ilke" şeklinde düzenlenmiştir. TTK m 1534/I'e göre Kanunda yer verilen madde başlıkları da Kanunun lafzına dahildir. Bu durumda TTK'nın "nama yazılı pay" ile "nama yazılı pay senedi" kavramlarını birbirinden ayırdığı belirtilebilir. Başka bir ifadeyle TTK sadece pay senetlerinde değil, senede bağlanmamış paylarda da nama ve hamiline yazılı pay şeklinde bir ayrım yapmaktadır. Çalışmamızda Kanunda yer verilen terminoloji kullanılmaktadır. Öğretimizde de senede bağlanmamış payların aynen pay senedi gibi nama veya hamiline yazılı olmak üzere ikiye ayrıldığı savunulmuştur [Ünal Tekinalp in Reha Poroy, Ünal Tekinalp and Ersin Çamoğlu, Ortaklıklar Hukuku, vol 1 (Vedat 2014) 552 para 768]. Ancak bu noktada bir görüş birliği yoktur. Zira öğretide söz konusu ayrım eleștirilmekte, hatta Kanunda bu ayrımın kavramsal olarak yeknesak bir șekilde kullanılmadığı belirtilmektedir. Bu bağlamda eleştiriler ve öneriler için bkz Şafak Narbay, '6102 Sayılı Yeni Türk Ticaret Kanunu'na Göre Anonim Ortaklıkta Pay ve Pay Senetlerinin Devri' (2012) XVI (3-4) EÜHFD 201, 201-206. TTK'nın anılan terminolojisine ilişkin tartışmalar Eski TTK dönemi öğretisine dayanmaktadır. Bu yönde tartışmalar ve öneriler için bkz Şafak Narbay, Anonim Ortaklıkta Pay Defteri (Seçkin 2003) $60 \mathrm{vd.}$ 
edilmektedir ${ }^{10,11}$. Dolayısıyla, öngörülüş amaçları yönünden karşılaştırıldıklarında, önalım haklarıyla bağlam düzenlemeleri arasında çok yakın bir ilişki ve benzerlik olduğu görülmektedir ${ }^{12}$. Ancak Kanunun öngördüğü bağlam düzeninin mevcut pay sahipliği yapısındaki güç ilişkilerini korumak bakımından kendi başına bir güvence oluşturamayacağ belirtilmektedir $^{13}$. Bu nedenle, pay sahipleri sözleşmeleri ile düzenlemelere gidilmesi gerektiğine işaret edilmektedir ${ }^{14}$. Çünkü doğrudan doğruya pay sahipleri arasında kararlaştırılan önalım hakları (borçlar hukuku anlamında) sözleşmesel düzeyde değerlendirilmelidir. Ortaklıkla payını devretmek isteyen pay sahibi arasındaki ilişki ise bundan farklıdır ${ }^{15}$. Bu husus Kanunun çizdiği sınırlar çerçevesinde esas sözleşmesel düzenin bir parçası olabilir.

Esas sözleşmesel bağlam olană̆ı TTK m 492/I uyarınca sadece nama yazılı paylar için mümkündür ${ }^{16}$. Buna karşın hamiline yazılı pay senetlerinin devri sınırlandırılamaz, böyle bir sınırlandırma esas sözleşmeyle getirilmiş olsa da geçerli değildir ${ }^{17}$. Oysa sözleşmesel önalım hakkı her tür pay için mümkün olabilir. Bağlam olanağı ortaklık paylarının borsaya kote olması halinde ciddi anlamda kısıtlıdır (bkz TTK m $495 \mathrm{vd}$ ). Oysa sözleşmesel önalım hakkı bakımından ortaklığın türünü esas alan herhangi bir kısıtlamadan da bahsedilemez. Keza, bağlam kuralları ortaklıklar hukukuna özgü eşit işlem ilkesine (bkz TTK m 357) tabidir. Oysa ortaklıklar hukukunun öngördüğü eşit işlem ilkesini aşan bir düzenleme arzulanıyorsa, bu, bağlam yoluyla yapılamaz. Böyle bir düzen ancak pay sahipleri sözleşmesi aracıllı̆ıyla kurulabilir ${ }^{18}$. Arzulanan düzene hizmet ettiği ölçüde sözleşmesel önalım hakkından yararlanılabilir.

Payları borsaya kote olmayan anonim ortakliklar bakımından, TTK m 493/III ayr1 tutulursa, kural olarak sadece esas sözleşmede öngörülen önemli sebeplere istinaden bir pay devrine onay verilmeyebilir. Bunun dışında önalım hakkına benzer bir esas sözleşmesel bağlam, ortaklığın "devredene, paylarını, başvurma anındaki gerçek değeriyle, kendi veya diğer pay sahipleri ya da üçüncü kişiler hesabına almayı

10 Bu hususta bkz Bösiger (n 1) 1, 4. Gerçekten anonim ortaklıklar hukukunun nama yazılı paylar bakımından öngördüğü bağlam sistemi, taraflar arasında yapılan önalım hakkı sözleşmeleriyle benzer amacı taşıyabilmektedir. Bu amaç ögretide, "anonim ortaklığın özgün yapısını koruma" amacı olarak da anılmaktadır [bu hususta bkz Hasan Pulaşlı, Şirketler Hukuku Şerhi, vol 2 (Adalet Yayınevi 2014) 1614-1615 para 30].

${ }_{11}$ Hukukumuzda da "kapalı veya aile tipi anonim ortaklıklar" ile "kişisel nitelikli anonim ortaklıklar" bakımından bağlam sisteminin uygulama alanı bulduğu belirtilmektedir [bkz Pulaşlı (n 10) 1616-1617 para 33-35].

12 Bkz Bahtiyar (n 8) 83, 88 ve 99. Hukukumuzda özellikle kapalı veya aile tipi anonim ortaklıklar bakımından payların önalım, alım, geri alım, öneriye muhatap olma gibi hakların konusu yapılmaya çalışıldığı, bunun amacının da yabancılaşmayı önleme olduğu vurgulanmaktadır [bkz Tekinalp (n 9) 605 para 851].

13 Bkz Bösiger (n 1) 1, 4-5; Forstmoser and Küchler (n 7) 371 para 1170-1171.

14 Bkz Bösiger (n 1) 1, 5 .

15 Bu bağlamda bkz Hanspeter Kläy, Die Vinkulierung (Helbing \& Lichtenhahn 1997) 486.

16 Bağlam senede değil, paya bağlandığından, pay senedi yerine çıkarılan ilmühaberler ve çıplak payları da kapsar [bu hususta bkz Pulaşlı (n 10) 1623 para 48].

17 ibid 1623 para 49 .

18 "Pay sahipleri arasında yapılmış bir pay sahipleri sözleşmesi eşit işlem ilkesine aykırı düşen hükümler içeriyorsa kural olarak böyle bir hüküm nedeniyle sözleşme taraflarının birbirlerine karşı eşit işlem ilkesine dayanan bir talebi olamaz” [bkz Okutan Nilsson (n 6) 168]. 
önererek", onay istemini reddedebilmesidir. Fakat sözleşmesel önalım hakkından farklı olarak bu olasılıkta ortaklık etkindir ve ancak payların gerçek değeri esas alınabilmektedir. Oysa pay sahipleri sözleşmelerinde yer verilen önalım hakkına ilişkin düzenlemelerde sözleşmenin tarafları etkindir ve değer hususuysa hukukun sınırları içinde serbestçe belirlenebilir ${ }^{19}$. Öğretimizde, "Kanunda öngörülen bir takım koruyucu hükümleri ortadan kaldıran pay sahipleri sözleşmesi hükümlerinin" geçersiz olduğu belirtilmiştir. Buna göre örneğin payların gerçek değer üzerinden satın alınmasına ilişkin koruyucu hükmü ortadan kaldıran pay sahipleri sözleşmesi hükümlerinin sözleşme serbestisi kapsamında değerlendirilmesi mümkün olmayıp bu yöndeki bir düzenlemenin Kanuna aykırılık (BK m 27) nedeniyle hükümsüz olduğu savunulmaktadı2 ${ }^{20}$. Aşağıda ayrıca belirtildiği üzere, esas sözleşmeler ortaklıkla ve özellikle ortaklık ile pay sahipleri arasındaki ilişkilerle ilgili hususları düzenler. Esas sözleşmeler kural olarak pay sahipleri arasındaki hukuki ilişkilere dair düzenleme yapamazlar. Özellikle ilgili görüsşte referans olarak değerlendirilen TTK m 493/VII ile "gerçek değere" ilişkin TTK m 493/I gibi kurallar esas sözleşmelere ilişkin ilkeler getirmekte ve kural olarak pay sahiplerinin kendi aralarındaki ilişkileri düzenlememektedir. Dolayısıyla bu düzenlemelere dayanarak pay sahiplerinin kendi aralarındaki hukuki ilişkinin hükümsüzlük yaptırımına tabi tutulması düşünülemez. Zira bu sadece sözleşmesel önalım hakkıyla ya da pay sahipleri sözleşmesi özelinde de değerlendirilemez. Aynı yaklaşımla pay sahibinin paylarını gerçek değer dışında bir değer üzerinden devir edememesi de öne sürülebilir. Gerçek değere ilişkin kural bağlam hükümleri ve özellikle kaçış klozu çerçevesinde esas sözleşmeye konulacak kurallara yapılan bir müdahaledir. Bu alanı ortaklıklar hukukunun dışına çıkarmamak gerektiği kanısındayız.

Pay sahipleri sözleşmeleri içinde yer verilen önalım hakkı hükümlerinin etkisi bağlam düzenlemelerine göre daha zayıftır. Kanunî ya da esas sözleşmesel bağlam, "aynî benzeri" nitelikte bir etkiye sahiptir ${ }^{21}$. Buna karşın aşağıda yer verildiği üzere, sözleşmesel alım, önalım hakkı gibi haklar sözleşme tarafları arasında bir etki gösterir, yani nisbi etkilidir²2. Öğretimizde limited ortaklıklar bakımından, alım, önalım ve geri alım gibi haklar tanıyan ortaklık sözleşmesi hükümlerinin bağlayıcı olacağı haklı olarak ifade edilmektedir. Ancak anonim ortaklıklar bakımından herhangi bir düzenleme yapılmadığı için buna yönelik esas sözleşme hükümlerinin “ortaksal nitelik kazanamayacağı, anonim ortaklığı ve pay sahiplerini bağlamayacağı,

19 Payların gerçek değerinden ayrılan bir önalım hakkı düzenlemesi ancak pay sahipleri sözleşmesiyle olanaklıdır [bu hususta bkz Kläy (n 15) 489]. Yoksa esas sözleşmesel herhangi bir düzenlemeyle metinde anılan hüküm aşılamaz. Aşağıda önalım hakkı içeren sözleşmede bedel hususuna ilişkin açıklamalara yer verilmiştir.

20 Görüș için bkz Necdet Uzel, 6102 sayıl Türk Ticaret Kanunu ve 6362 sayll Sermaye Piyasası Kanununa Göre Anonim Ortaklıkta Esas Sözleşmesel Bağlam (On İki Levha 2013) 139 dipnot 102.

21 Bu bağlamda bkz Pulaşlı (n 10) 1665 para 163.

22 Limited ortaklıklar bakımından durum farklıdır. TTK m 577/I b uyarınca, önalım hakkı şirket sözleşmesinde öngörüldüğü takdirde bağlayıcı bir hal alır. Oysa, önalım, alım ve geriye alım gibi hakların anonim ortaklık esas sözleşmesinde yer alsa bile ortaksal nitelik kazanamayacağı, ortaklığı ve ortaklık organlarını bağlamayacağı öğretide ifade edilmektedir [bu bağlamda bkz Ünal Tekinalp, Anonim Ortaklıkta Yeni Bağlam Sisteminin Esasları (Vedat 2012) 84]. 
bağlama ilişkin TTK m 491 vd hükümlerinin de buna olanak vermeyeceği" ifade edilmektedir ${ }^{23}$. Dolayısıyla sözleşmesel önalım hakkı esas sözleşmesel bağlam olanağına bir alternatif olarak düşünülmemelidir. Anonim ortaklıklar hukukunun tanıdığı bağlam olanağı yanında, pay sahipleri sözleşmeleriyle önalım hakk1 kararlaştırılmasında büyük fayda vardır. Somut olayda pay sahipleri sözleşmesindeki önalım hakkı bir şekilde uygulanmamış olursa, ortaklığın TTK m 493'te düzenlenen "kaçış klozundan" faydalanarak devre onay vermemesi, koşulları da oluşmuşsa, tamamlayıcı bir çözüm olarak gündeme gelebilir ${ }^{24}$.

\section{Sözleşmesel Önalım Hakkı ve Buna Yönelik Sözleșmenin Hukuki Niteliği}

Sözleşmesel önalım hakkı, yükümlünün bir şeyi satması ya da satım sonucu doğuracak şekilde devretmesi halinde, hak sahibinin o şeyi iktisap etmesini sağlamaya yönelik bir yetkidir ${ }^{25}$. Bu hak, yükümlüye yöneltilecek tek $\operatorname{tarafl}^{26}$ ve ulaşması gerekli bir irade beyanıyla kullanılmaktadır. Malikin bir kişiye önalım hakkı tanımak için yaptığı sözleşmeye de önalım sözleşmesi denmektedir ${ }^{27}$. Öğretide sözleşmesel önalım hakkının değişik tanımları yapılmaktadır. Ancak bu tanımlar önalım hakk1 ve önalım sözleşmesinin hukukî niteliği hususunda kabul edilen görüşe göre değişebilmektedir. Bu hususta değişik görüşler olmasına rağmen öğretide öne çıkan iki görüşe aşağıda kısaca değinmek mümkündür.

Önalım hakkı çoğunlukla yenilik doğurucu hak olarak nitelenmektedir ${ }^{28}$. Öğretide önalım hakkının bu niteliğinin en isabetli şekilde kuruluş teorisi tarafından açıklandığ1 belirtilmektedir ${ }^{29}$. Kuruluş teorisine göre, taraflar arasında söz konusu yenilik doğurucu hakkın usule uygun kullanımıyla bir satım sözleşmesi kurulmaktadır ${ }^{30}$. Yani, önalım sözleşmesi, hakkın yükümlüsünün, hak sahibine, önalım olayına bağlı olarak

23 Bu hususa ilişkin olarak bkz Tekinalp (n 9) 605 para 852.

24 Pay sahipleri sözleşmeleri yanında ayrıca esas sözleşmesel bağlam düzenlemelerine de yer verilmesi gerektiği ve bunun önemi hususunda bkz Hintz-Bühler (n 4) 140.

25 Bu bağlamda bkz Bösiger (n 1) 1, 5 dipnot 10. Benzer olarak bkz Germann (n 6$) 695$ para 1617; Zobl (n 6) 401, 402; Fischer (n 6) 62 .

26 Alım, önalım ve geriye alım haklarının tek taraflı bir beyan ile kullanıldı̆̆ı noktasında bkz Bahtiyar (n 8) 83, 83.

27 Bkz Yavuz, Acar and Özen (n 8) 254.

28 Ortaklık paylarıyla ilgili olarak bu yönde bkz Vischer (n 3) 82, 83; Forstmoser and Küchler (n 7) 375-376 para 1180; Germann (n 6) 695 para 1618; Fischer (n 6) 63; Okutan Nilsson (n 6) 216. Taşınmaz satımlarıyla ilgili olarak bu yönde bkz Agnes Atteslander-Dürrenmatt, 'Art 216-221, 229-236' in Jolanta Kostkiewicz and others (eds), OR Kommentar - Schweizersiches Obligationenrecht (3rd edn Orell Füssli 2016) Art 216 para 8; Hans Giger, Berner Kommentar zum schweizerischen Privatrecht, Der Grundstückkauf, Art. 216-221 OR, vol VI/2/1/3 (Heinz Hausheer ed Stämpfli 1997) Art 216 para 84. Hukukumuz açısından bu yönde bkz Feride Demirbaş, 'Sözleşmeden Doğan Önalım Hakkı' (2016) 65 (2) AÜHFD 249, 252; Aydın Zevkliler and Emre Gökyayla, Borçlar Hukuku - Özel Borç İlişkileri (Turhan 2013) 69; Yavuz, Acar and Özen (n 8) 254. Öğretimizde borçlar hukuku bağlamında önalım, alım ve geri alım hakları "satış ilişkisi doğuran haklar" olarak ele alınmakta ve kurucu yenilik doğurucu hak olarak kabul edilmektedir [bkz Mahmut Kizir, ‘6098 Sayılı Türk Borçlar Kanununa Göre Satış İlişkisi Doğuran Haklar ve Özellikle Önalım Hakkına İlişkin Hükümlerin Değerlendirilmesi' (2016) 22 (3) MÜHF-HAD (Prof. Dr. Cevdet Yavuz'a Armağan, vol 2) 1773, 1775].

29 Bkz Vedat Buz, Medeni Hukukta Yenilik Doğuran Haklar (Yetkin 2005) 158.

30 Taşınmaz satımlarıyla ilgili olarak bu yönde bkz Atteslander-Dürrenmatt (n 28) Art 216 para 8. 
yapılacak tek taraflı bir irade açıklamasıyla önalım konusu üzerinde satış sözleşmesi kurmaya yönelik, yenilik doğurucu bir hak tanıdığ1 "sui generis" bir sözleşmedir" Hukukumuzda hâkim görüş kuruluş teorisini esas almaktadır ${ }^{32}$. Buna karşılık koşul teorisi, önalım hakkı içeren sözleşmeyi, çift geciktirici koşula bağlı bir satım sözleşmesi ${ }^{33}$ olarak dikkate almaktadır. Bu koşullardan birisi, önalıma mahal verecek olayın gerçekleşmesidir ve tesadüfî bir koşul ${ }^{34}$ oluşturur. Diğeriyse önalım hakkının kullanılmasıdır ki, bu da sözleşmenin iradi koşulunu oluşturmaktadır ${ }^{35}$. Buna göre de önalım hakkı, hakkın konusu şeye ilişkin olarak, yükümlünün üçüncü bir kişiyle satım sözleşmesi yapması koşuluna bağlı kullanılan bir alım hakkıdır. Tanımda yer verilen alım hakkı ise, hak sahibinin, satım yükümlüsüne yönelttiği tek taraflı ulaşması gerekli bir irade beyanıyla onunla önceden kararlaştırdıkları fakat henüz hak sahibini bağlayıcı olmayan bir sözleşmeyi yürürlüğe koyan bir hak olarak açıklanmaktadır ${ }^{36}$.

Öğretide, önalım hakkı içeren sözleşmenin (kuruluş teorisi uyarınca) sui generis bir sözleşme veya geciktirici koşula bağlı bir satım sözleşmesi olarak nitelendirilmesinin hukuki sonucu etkilemeyeceği belirtilmektedir. Zira sui generis sözleşme görüşüne (kuruluş teorisine) başvurulduğunda da kıyasen satım sözleşmesi hükümlerinin uygulama alanı bulacağı belirtilmektedir ${ }^{37}$. Dolayısıyla çalışmanın boyutu ve tartışmanın konumuz üzerindeki etkisi dikkate alınarak görüş ayrılıklarına derinlemesine girilmeyecektir. Ancak yeri geldiğinde iki görüşe göre de ulaşılan sonuçlara işaret edilecektir.

Sözleşmesel önalım hakkı ile özellikle "gerçek önalım hakkı” kast edilmektedir ${ }^{38}$. Bundan anlaşılması gereken, pay üzerindeki önalım hakkının yukarıda aktarılan

31 Teoriye ilişkin olarak bkz Jonas Rüegg, Rechtsgeschäftliche Vorkaufsrechte an Grundstücken (Jörg Schmid ed Schulthess 2014) 20-21 para 67.

32 Bu yönde bkz Buz (n 29) 158; Fikret Eren, Borçlar Hukuku Özel Hükümler (Yetkin 2017) 201; Fikret Eren, Mülkiyet Hukuku (Yetkin 2011) 434; Demirbaș (n 28) 249, 253. Keza, anonim ortaklıklar hukukumuz bakımından Okutan Nilsson (n 6) 217'ye göre, "eğer önalım hakkı sahibi bu hakkını kullanırsa, yani payları almak iradesini beyan ederse, beyanın karşı tarafa varması ile kendisiyle önalım hakkını tanımış olan kişi arasında satım sözleşmesi kurulmuş olur". Buna göre anonim ortaklıklar hukukumuzda anılan yazarın kuruluş teorisini esas aldığı kabul edilebilir.

33 Öğretide uzun süredir savunulan bu görüş, önalım sözleşmesini satım sözleşmesinin özel bir türü olarak değerlendirmektedir [bkz Arthur Meier Hayoz and Ümit Doğanay (trs), 'Şuf'A Akdi' (1967) 33 (3-4) İ̈HFM 273, 274].

34 Sözleşme yükümlüsünün üçüncü bir kişiyle pay devri amacı güden bir sözleşme yapmasının tesadüfî koşul olarak nitelendirilmesi ilk bakışta yanlış algılanabilir. Zira, "sözleşmenin taraflarından birinin iradesi dışındaki olaylara bağlanan şarta tesadüfî şart denmektedir”. Öğretide, "üçüncü bir kişinin sözleşmeye izin vermesi şartıyla yapılması halinde de tesadüfî şart" söz konusu olduğu belirtilmektedir [alıntılar için bkz Fikret Eren, Borçlar Hukuku Genel Hükümler (Yetkin 2015) 1170]. Bu durumda sözleşme yükümlüsünün üçüncü kişiyle yapacağı pay devri sözleşmesi aslında alıcı tarafın kabulüne bağlanmaktadır. Yani önalım hakkı içeren sözleşmenin yükümlüsü sadece kendi iradesiyle söz konusu koşulu gerçekleştirebilecek durumda değildir. Bu nedenle anılan koşulun tesadüfî koşul olarak nitelendirilmesi gerekmektedir.

35 Koşul teorisi, özellikle İsviçre öğretisinde ciddi anlamda taraftar bulmaktadır. Bu yönde bkz Vischer (n 3) 82, 83; Giger (n 28) Art 216 para 157; Germann (n 6) 695 para 1618; Fischer (n 6) 62. Taşınmaz satımlarıyla ilgili olarak bu yönde bkz Atteslander-Dürrenmatt (n 28) Art 216 para 8. Alım hakkının da koşul teorisine göre açıklandığı belirtilebilir [bu hususta bkz Gloor and Flury (n 7) 305, 306]. Hukukumuzda bu görüşte bkz Aydoğdu and Kahveci (n 8) 277 ve 284.

36 Taşınmaz satımlarında, alım ve önalım haklarıyla ilgili olarak bu yönde bkz Urs Fasel, 'Art 216-216e' in Heinrich Honsell, Nedim Peter Vogt and Wolfgang Wiegand (eds), Basler Kommentar, Obligationenrecht I, Art. 1-529 OR, vol 1 (Helbing Lichtenhahn 2011) Art 216 para 9-10.

37 Bu bağlamda bkz Forstmoser and Küchler (n 7) 375-376 para 1180.

38 Bu nedenle çalışmada aksi belirtilmedikçe "önalım hakkı" ifadesi, "gerçek önalım hakkını" belirtmektedir. 
özellikleri taşıması ve değinilen teorilere göre açıklanabilmesidir. Somut olayda pay üzerindeki hakkın yenilik doğurucu karakterde olup olmaması söz konusu ayrımdaki en önemli kriterdir. Öğretimize göre yenilik doğurucu bir hak değil de yalnızca paylarını satmak isteyen ortağın öncelikle belirli kişilere öneride bulunması zorunluluğu öngörülmüş ise, "gerçek olmayan önalım hakkı" veya "önalım benzeri hak" söz konusudur ${ }^{39}$.

Anonim ortaklık pay sahipleri sözleşmeleri bakımından önalım hakkı düzenlenmemiştir. $\mathrm{Bu}$ nedenle pay sahipleri sözleşmeleriyle önalım hakk1 düzenlenmesi ve olası uyuşmazlıklarda uygulanacak hükümler tespit edilmelidir. Sözleşmenin hukukî niteliğine ilişkin tartışmaların ortak yönleri değerlendirildiğinde, bu hususta taşınmaz satımına ilişkin BK m 237 vd hükümlerinden yararlanmak mümkündür ${ }^{40}$. Anılan hükümler uygulanırken somut olayda sözleşme konusunun taşınmaz değil, anonim ortaklık payı olduğu her zaman dikkate alınmalıdır. Keza önalım hakkı öngören sözleşmenin ne tür bir pay sahipleri sözleşmesi içinde yer aldığ1 da aynı derecede önem göstermektedir. Bu nedenlerle söz konusu hükümler taraflar arasındaki hukukî ilişkide, doğrudan doğruya uygulama alanı bulamaz. Ancak, uygun düştüğü ölçüde, kıyasen uygulama alanı bulabilir ${ }^{41}$.

\section{Hakkın Öngörülme Şekli}

\section{A. Kural: Şekil Serbestîsi}

Önalım hakkı, genelde pay sahipleri sözleşmelerinin bir parçasıdır. Pay sahipleri sözleşmeleri, içindeki özel hükümler yazılı veya başka bir özel şekli

\footnotetext{
39 Bkz Bahtiyar (n 8) 83, 90. Ayrıca belirtelim ki, Tekinalp'e göre, gerçek olmayan önalım hakk1 "önerilmeye muhatap olmanı" bir türüdür ve bu TTK m 466'daki haktan farklıdır [bkz Tekinalp (n 22) 86]. Aynı yazar, Tekinalp (n 9 ) 606 para 855 'te gerçek olmayan önalım hakkı kavramını şu şekilde açıklamıştır: “Önalım hakkı, payların satışı halinde kullanılan yenilik doğurucu bir hak halinde düzenlenmeyip sadece, satmak isteyen pay sahibinin önce pay sahiplerine veya bunlardan bazılarına öneride bulunmaları şeklinde öngörülmüş ise gerçek olmayan önalım hakkı veya önalım benzeri hak söz konusudur. Satış olgusuna bağlı önalım hakkı gerçek önalım hakkıdır”. Gerçek olmayan önalım hakkının esas sözleşmelerde geçerli olarak yer alıp alamayacağı mevzusu tartışmalıdır. Öğreti açısından bkz III, C, 1. Uygulamada bu hususun neden olduğu sorunlar için bkz VI, B, 2 .

40 Sözleşmesel önalım hakkının taşınmazlar bakımından düzenlenip, taşınırlar veya ortaklık payları bakımından düzenlenmemiş olması, bunlar üzerinde sözleşmesel bir önalım hakkı tesis edilemeyeceği anlamına gelmez. Bu hususta bkz Zobl (n 6) 401, 402. Hukukumuz açısından bkz Okutan Nilsson (n 6) 215; Bahtiyar (n 8) 83, 83; Demirbaş (n 28) 249, 254; Aydoğdu and Kahveci (n 8) 289; Eren, Özel (n 32) 200. Hukukumuzda önceden de bu hususta tartışmalar ele alınıp değerlendirilmiş ve taşınırların sözleşmesel önalım hakkına konu olabileceği sonucuna ulaşılmıştır [bu hususta bkz Feyzi N Feyzioğlu, 'Şuf'a Hakkının Mevzuu ve Süjeleri' (1952) 18 (3-4) İ̈HFM 875, 882].

${ }_{41}$ Ortaklık paylarıyla ilgili olarak bu yönde bkz Vischer (n 3) 82, 83; Forstmoser and Küchler (n 7) 375-376 para 1180; Zobl (n 6) 401, 403. Benzer yönde hukukumuz açısından bkz Okutan Nilsson (n 6) 215. Anılan hükümlerin menfaatler dengesinin uyduğu diğer durumlarda da uygulanabileceğini belirtmek yanlış olmaz. Örneğin, İsviçre hukukunda, önalım olayı, yani, satım veya ona eşdeğer bir durumun ortaya çıkması vakıası hakkında OR m 216c'nin uygulanabileceği belirtilmektedir. Fasel (n 36) Art 216c para 2'ye göre, anılan koşul, taşınırlar ve taşınmazlar açısından aynı şekilde tanımlanabileceği için konuya ilişkin olarak yapılan açıklamalar diğer "tüm” önalım ilişkilerine kıyasen uygulanabilir. Oysa şekli olarak OR m 216c düzenlemesi sadece taşınmazlar hakkında geçerlidir. Keza, Hintz-Bühler (n 4) 89'da ortaklık paylarında önalım bedeliyle ilgili olarak OR m 216d/III düzenlemesinin uygulanabileceğini belirtmektedir. Yazar aynı yerde özellikle dipnot 361'de, OR m 216d/III'ün aslen taşınmazlar için öngörüldüğünü ancak gerekçeye göre, bunun uygun düştüğü ölçüde taşınırlara da uygulanabileceğini belirtmektedir.
} 
gerektirmedikçe herhangi bir geçerlilik şekline tabi değildir ${ }^{42}$. Bu durumda, pay sahipleri sözleşmelerinde yer verilen önalım hakkına ilişkin hükümlerin özel bir şekle tabi olup olmadığı değerlendirilmelidir. BK m 237/III, önalım sözleşmelerinin geçerliliğini yazılı şekilde yapılmış olmasına bağlamaktadır. Yukarıda belirtildiği üzere, taşınmazlara ilişkin olarak Kanunda öngörülen söz konusu hükümler, anonim ortaklık payları hakkında ancak kıyasen uygulama alanı bulabilmektedir. Hukukumuzda kural şekil serbestîsidir (bkz BK m 12/I). Bu nedenle BK m 237'de olduğu gibi, kuraldan sapan durumlar, Kanunlarda açıkça belirtilmektedir. $\mathrm{Bu}$ manada istisnalar dar yorumlanmalı ve kural uygulanmalıdır. Dolayısıyla anonim ortaklık paylarına ilişkin yapılacak önalım sözleşmeleri bakımından herhangi bir şekil zorunluluğundan bahsedilememelidir ${ }^{43}$.

Sözleşmesel önalım hakkının kural olarak herhangi bir şekle bağlı olmadığı saptandıktan sonra, şekil hususunun her somut olayda ayrıca dikkate alınması gerektiği de belirtilmelidir. Örneğin, taraflar, yapılan sözleşme için BK m 17 uyarınca iradi bir şekil kararlaştırmışlarsa önalım hakkına ilişkin sözleşmenin de bu şekilde yapılması gerekir.

\section{B. Ölüme Bağlı Önalım Hakkı Tanınması}

\section{Sözleșmenin Bütün Olarak Değerlendirilmesi}

İsviçre hukukunda, sözleşme unsurları veya içeriği değerlendirilerek bazen bunun şekle tabi olabileceği ifade edilmiştir. Mesela pay sahibinin ölümünden sonraya etkili olmak veya salt ölümüyle birlikte etkili olmak üzere kabul edilmiş bir önalım hakkının koşullara göre miras hukukuna ilişkin kurallara uyulmak suretiyle yapılması gerektiği belirtilmiştir ${ }^{44}$. Ancak alım hakkı bakımından bu hususun tartışmalı olduğunu ifade etmek gerekir. Benzer hukuki nitelikleri nedeniyle, aynı tartışmalar önalım hakkı için de önemlidir. Özellikle çok taraflı bir "pay sahipleri sözleşmesi çerçevesinde" taraflardan birisinin ölümü üzerine kararlaştırılan alım hakkının "kural olarak" sağlar arası işlem şeklinde niteleneceği görüşünün öğretide hâkim olduğunu belirtebiliriz ${ }^{45}$. Bu görüşün oluşmasında, İsviçre Federal Mahkemesi’nin ölüme bağl1 tasarruflarla

\footnotetext{
42 Bu hususta özellikle bkz Okutan Nilsson (n 6) 73-74. Aynı yönde bkz Gloor and Flury (n 7) 305, 306; Josef Rütter and Kilian Zwyssig, 'Aktionärbindungsverträge' (2010) (3) TREX 142, 142.

43 Bu bağlamda bkz Forstmoser and Küchler (n 7) 376 para 1182; Hintz-Bühler (n 4) 95; Vischer (n 3) 82, 83; Zobl (n 6) 401, 404. Hukukumuzda örneğin taşınmazlarla ilgili alım ve geri alım sözleşmelerinin resmi şekil zorunluluğuna tabi olduğu, fakat taşınırlara ilişkin aynı sözleşmelerin bir şekle uyulmaksızın yapılabileceği belirtilmektedir [bkz Kizir (n 28) 1773, 1777].

44 Bu hususta bkz Forstmoser and Küchler (n 7) 376 para 1182. Öğretimizde taşınmazlara ilişkin önalım hakkı bakımından benzer bir yaklaşım mevcuttur. Buna göre, "aksine bir anlaşma mevcut olmadığı için miras yoluyla intikali sağlamak üzere önalım hakkı üzerinde vasiyetname veya miras sözleşmesi ile ölüme bağlı olarak tasarrufta bulunuluyorsa, ölüme bağlı tasarrufların şekli bakımından TBK m 239/II değil, TMK m 531 vd uygulama bulur" [bkz Mustafa Alper Gümüș, ‘6098 Sayı1ı Türk Borçlar Kanunu'nun Akdi Önalım Hakkına İlişkin Hükümlerinin (TBK m 237/III, 238, 239 ve 240-242) Değerlendirilmesi' (2011-2012) 8-9 (2-1) YÜHFD (Prof. Dr. Erhan Adal'a Armağan) 435, 439].

45 Bu bağlamda bkz Hintz-Bühler (n 4) 95; Gloor and Flury (n 7) 305, 312; Germann (n 6$) 695$ para 1616.
} 
sağlar arası işlemlerin ayrımına ilişkin bir kararı büyük etki göstermektedir. Kararda, etkilerini muris hayattayken göstermeye başlayan işlemlerin ölüme bağlı tasarruf olamayacağı, fakat bunun aksininse doğrudan savunulamayacağ 1 vurgulanmaktadır. Çünkü sağlar arası bir işlemin etkilerinin, murisin ölümüyle ortaya çıkacağı da kararlaştırılabilir. Mahkeme bu nedenle ortada sağlar arası bir işlem mi yoksa ölüme bağlı tasarruf mu olduğunun soyut bir kritere bağlanamayacağını belirtmektedir ${ }^{46}$. Dolayısıyla, somut olayın tüm koşulları değerlendirilip yorumlanarak bir sonuca ulaşılmalıdır ${ }^{47}$. Bu noktada mahkeme, somut olayın tüm koşulları incelenirken, her şeyden önce, sözleşme taraflarının iradelerinin (sözleşmeyi yapma amaçlarının) değerlendirilmesi gerektiğini hükme bağlamıştır. Taraflarca yapılan işlemin yükümlünün malvarlı̆̆ını mı yoksa öncelikle onun terekesini mi etkilemekte olduğu ortaya konmalıdır. Özellikle tarafların iradelerine göre sözleşmenin etkilerini ne zaman göstermeye başlayacağı değerlendirilmelidir ${ }^{48}$.

İsviçre Federal Mahkemesi'nin anılan kararında yer verilen, somut olayın tüm koşullarının değerlendirilmesi gerektiğine dair esas gerçekçidir. $\mathrm{Bu}$ nedenle, sözleşmesel önalım ve alım haklarına dair düzenlemelere hangi koşullar içinde rastlandığ1 ortaya konmalıdır. Pay üzerinde sözleşmesel önalım veya alım hakkı düzenleyen taraflar, bu hükümlere genelde bir bütünün içinde yer verirler. Bu da belirtildiği üzere, pay sahipleri sözleşmesidir. Değerlendirmede somut olayın bütün koşulları dikkate alınacağına göre, bahsedilen şekil sorununun çözümünde, sözleşmesel önalım ya da alım haklarının hukuki niteliği kadar bunların içinde yer aldığ̣ pay sahipleri sözleşmesinin hukuki niteliği de etkilidir.

\section{Adi Ortaklık Niteliği Taşıyan Pay Sahipleri Sözleşmeleri}

\section{a. Basit ve Nitelikli Halefiyet Klozu Kavramları}

Pay sahipleri sözleşmeleri çoğunlukla adi ortaklık sözleşmesi olarak nitelendirilmektedir. Bu sözleşmede, taraflardan birisinin ölümü halinde kalanlara önalım hakkı tanınıyorsa konumuzla ilgili bazı sonuçlara ulaşmak mümkündür. Öncelikle bu durumda, ilgili adi ortaklığın ölüm halinde mirasçılarla devam edeceğinin kararlaştırıldığı sonucuna ulaşılmalıdır. Zira adi ortaklıkta ortaklardan birisinin ölümü bir sona erme sebebidir (bkz BK m 639/I/2). Fakat yapılan sözleşmeyle ölümün bir sona erme sebebi olmaktan çıarılması mümkündür. Buna göre, ortaklardan birisinin ölümü halinde, mirasçılarla pay sahipleri sözleşmesi devam edecek, fakat mirasçılar ellerindeki anonim ortaklık payını üçüncü bir kişiye devrederlerse sözleşme tarafları

\footnotetext{
46 Bu yöndeki İsviçre Federal Mahkemesi kararı için bkz BGE 99 II 268, 271-272 (Karara İnternet erişimi için bkz <http:// www.bger.ch/index/juridiction/jurisdiction-inherit-template/jurisdiction-recht/jurisdiction-recht-leitentscheide1954.htm> Erişim Tarihi 28 Ağustos 2017).

47 Mahkemenin de kararına atıfla, ayrımın oldukça nazik bir mesele olduğu yönünde bkz Forstmoser and Küchler (n 7) 162 para 473.

48 Bu hususlarda bkz BGE 99 II 268, 272.
} 
önalım hakkını kullanabilecektir. Tam da bu noktada nitelikli ve basit halefiyet klozu arasında bir ayrım yapılabilir. Ana hatlarıyla ifade etmek gerekirse, ölüm halinde mirasçılarla ortaklığın devam edeceğine dair sözleşme koşulu "basit halefiyet klozu" olarak anılmaktadır. Buna karşılık ortaklığın belirli bazı mirasçılarla devam edeceğine dair sözleşme "nitelikli halefiyet klozu" olarak adlandırılmaktadır ${ }^{49}$.

\section{b. Önalım Hakkının Nitelikli Halefiyet Klozuyla Birlikte Yer Alması}

Sözleşmede nitelikli halefiyet klozu varsa, yani ölüm sonrası seçilmiş bazı mirasçılarla adi ortaklığın devamı öngörülmüşse, mirasçıları ilgilendiren bu hususun, ayrıca ölüme bağlı tasarrufların şekline de tabi olması gerekir. Çünkü böyle bir durumda, pay sahipleri sözleşmesindeki ortak sıfatından kaynaklanan konumun mirasçılara intikalinin koşulları yanında terekedeki bu konumun kaderine yönelik de bir düzenleme yapılmış olmaktadır ${ }^{50}$. Dolayısıyla söz konusu paylaştırmanın pay sahipleri sözleşmesine konulan hüküm yanında ayrıca ölüme bağlı tasarruf olarak da desteklenmesi gerekir ${ }^{51}$. Haliyle buna ilişkin şekil kurallarına uyulmalıdır. Ortağın iradesinin miras paylaşımına dönük kurallar getirmek olduğu böyle bir durumda, kalan ortaklara tanınan önalım hakkının seçilmiş mirasçılarla devamını öngören paylaştırma kuralıyla birlikte ölüme bağlı tasarrufların şekline tabi olması uygun olur. Zira artık önalım hakk1, terekedeki ortak konumunun kaderinin belirlenmesinin bir parçası olarak karşımıza çıkmaktadır.

\section{c. Önalım Hakkının Basit Halefiyet Klozuyla Birlikte Yer Alması}

Adi ortaklık niteliğindeki pay sahipleri sözleşmesinde taraflardan birisinin ölümü halinde, sözleşmenin tüm mirasçılarla devam edeceğine dair bir belirleme de yapılabilir. İsviçre öğretisi, adi ortaklığın taraflardan birisinin ölümü halinde tüm mirasçılarla devam edeceğine dair sözleşmenin, sağlar arası bir işlem olduğunu kabul etmektedir $^{52}$. Çünkü sözleşme taraflarının iradesi, terekedeki ortaklık sıfatından kaynaklanan konumun belli mirasçılara dağılımını kararlaştırmak değildir. Taraflar burada, anonim ortaklıkta birlikte hareket etmek üzere oluşturdukları sistemin içlerinden birinin ölümüyle sona ermemesini arzulamaktadır. Bu durumda, pay sahipleri sözleşmesindeki önalım hakkı, mirasçılarla devam hükmüyle birlikte kural olarak sağlar arası işlem sayılmalı ve ölüme bağlı tasarruflara ilişkin koşullara

\footnotetext{
$49 \mathrm{Bu}$ anlamdaki "basit" ve "nitelikli" halefiyet klozu ayrımı için bkz Daniel Staehelin, 'Art 545-551, 574-593, 619' in Heinrich Honsell, Nedim Peter Vogt and Rolf Watter (eds), Basler Kommentar, Obligationenrecht II, Art. 530-964 OR, Art. 1-6 SchlT AG, Art. 1-11 ÜBest GmbH, vol 2 (Helbing Lichtenhahn 2012) Art 545/546 para 10; Fischer (n 6$) 196$.

50 Pay sahipleri sözleşmelerinde mirasçılarla devam klozuna ilişkin olarak bu yönde bkz Forstmoser and Küchler (n 7) 189190 para 589.

51 Bu bağlamda ibid 194-195 para 584. Ortaklığın belirli bazı mirasçılarla devam edeceğine dair "nitelikli halefiyet klozu"nun yanında, ayrıca ölüme bağlı tasarruflara uygun şekilde bir düzenleme yapılması gerektiği hususunda ayrıca bkz Germann (n 6) 97 para 233; Karin Müller, 'Art 530-551' in in Jolanta Kostkiewicz and others (eds), OR Kommentar - Schweizersiches Obligationenrecht (3rd edn Orell Füssli 2016) Art 545 para 4; Hintz-Bühler (n 4) 179-180.

52 Bu bağlamda bkz Staehelin (n 49) Art 545/546 para 10.
} 
tabi olmamalıdır ${ }^{53}$. Fakat İsviçre Federal Mahkemesi'nin adi ortaklıkta ortaklardan birisinin ölümü halinde, kalan ortakların ortaklığa (mirasçılar olmaksızın) devamı ve mirasçılara ödenecek ayrılma payı ile ilgili bir kararı ilginç bir tartışmayı beraberinde getirmektedir. Buna göre, bir ortağın çıkması ve ölümü nedeniyle ortaklıktan ayrılması arasında, hesaplanacak ayrılma payı hususunda çok farklı koşullar öngören bir adi ortaklık sözleşmesi vardır ${ }^{54}$. Mahkeme ölüm nedeniyle hesaplanacak ayrılma payına ilişkin düzenlemenin ölüme bağlı tasarruf olarak dikkate alınıp alınamayacağını değerlendirmiştir. Mahkeme, ortağın ortaklıktan çıkması ile ölümü halinde hesaplanacak ayrılma payları arasında oluşacak ciddi hesap farklılı̆̆ını dikkate almış ve bu hususu kararda özellikle vurgulamıştır ${ }^{55}$. Çıkmayla hesaplanacak ayrılma payının, ölüme bağlı olarak hesaplanacak ayrılma payından önemli ölçüde yüksek olması mahkemece ölüme bağlı tasarruf olarak değerlendirilmiştir. Öğreti de buradan hareketle, pay sahipleri sözleşmesinde, ölüme bağlı bir "alım hakkı"nın, örneğin sağlar arasındaki bir devirden çok daha avantajlı bir fiyat belirlemesine tabi tutulmasının ölüme bağlı tasarruflara ilişkin şekle uygun olarak yapılıp yapılmayacağı sorununu gündeme getirmiştir ${ }^{56}$.

Pay sahipleri sözleşmesinde taraflardan birisinin ölümü halinde, kalanlara ölenin anonim ortaklık payları üzerinde "alım" hakkı tanınması ve bunun gerçek değerden daha düşük bir değer üzerinden yapılmasının ölüme bağlı tasarrufolarak nitelenmesinin zor olduğu ifade edilebilir. Öğretide, aradaki fiyat farkının temelinde, her durumda, birlikte hareket eden diğer pay sahiplerinin üstün tutulması amacının bulunmadığı belirtilmektedir ${ }^{57}$. Bir diğer husus da sözleşme anında münferit pay sahiplerinin, mirasçıları olumlu mu olumsuz mu etkileyeceğini bilemeyecek olmasıdır ${ }^{58}$. Örneğin, taraflardan birisinin ölümü halinde mirasçılarla devamı öngören bir pay sahipleri sözleşmesinde, mirasçıların ölümden sonra payı üçüncü kişilere devretme olasıllı̆ına karşı diğer sözleşme taraflarına payların nominal değeri üzerinden önalım hakk1 tanınmış olabilir. Ölümden bir süre sonra mirasçılar payı devretmek istediğinde, devredilen payların gerçek değeri nominal değerin çok üstünde olabileceği gibi çok altında da olabilir. Bu noktada, sözleşen tarafların ölüme bağlı bir tasarruftan ziyade, kurdukları sistemin belirli bir çevre içinde işlemeye devam etmesine yönelik bir irade gösterdiği belirtilebilir. Sağlar arası ortaya çıkan bu iradenin sonucunun mirasçıları etkilemesi ayrı bir husustur.

\footnotetext{
53 Bu hususta bkz Gloor and Flury (n 7) 305, 312. Ayrıca pay sahipleri sözleşmelerinde alım hakkının her zaman sözleşme taraflarının sağlığında etkilerini doğurmaya başlayan diğer hak ve yükümlülüklerle birlikte kararlaştırıldığı, bu nedenle de pay sahipleri sözleşmeleri çerçevesinde kararlaştırılan alım hakkının sağlar arası bir işlem olduğu yönünde bkz HintzBühler (n 4) 95.

54 Sözleşmenin detayları için bkz BGE 113 II 270, 270-271 (Karara internet erişimi için bkz <http://www.bger.ch/index/ juridiction/jurisdiction-inherit-template/jurisdiction-recht/jurisdiction-recht-leitentscheide1954.htm> Erişim Tarihi 7 Eylül 2017).

55 ibid 270, 273

56 Bu bağlamda özellikle bkz Gloor and Flury (n 7) 305, 312.

57 ibid 305, 312.

58 Özellikle alım hakkıyla ilgili olarak bu bağlamda bkz ibid 305, 312.
} 
İsviçre'de alım hakkı bakımından tartışılan ve öğretide de ciddi taraftar bulan sağlar arası işlem görüşü önalım hakkı için evleviyetle kabul edilmelidir. Zira, taraflar sözleşirken tüm mirasçılarla sözleşmenin devam edeceğini kabul etmiş ve sözleşme konusu anonim ortaklık paylarının mirasçılar tarafından üçüncü kişilere devrine karşı gerçek değerden farklılaşan bir hesaplama yöntemi içeren önalım hakkı belirlemişlerdir. Burada sözleşen tarafların sağlıklarında kurduğu pay sahipleri çevresi arasındaki ilişkiyi aynı konseptte devam ettireceklerine yönelik bir iradenin var olduğu ölüme bağlı olarak tanınan alım hakkından daha da açıktır. Yani pay sahipleri arasında oluşan adi ortaklığın ortak amacının istenilen kişi çevresi içinde devamı amaçlanmaktadır. Dolayısıyla sözleşmenin taraflarına, ölenin mirasçılarına karşı gerçek değere göre fiyat farkı yaratan olası bir önalım hakkı tanınması sağlar arası bir işlem kabul edilmeli ve özel bir şekle tabi olmamalıdır.

\section{Adi Ortaklık Niteliği Taşımayan Pay Sahipleri Sözleşmeleri}

Pay sahipleri sözleşmesinin genellikle bir adi ortaklık sözleşmesi niteliği taşıdığı kabulü bir kenara bırakılırsa ${ }^{59}$, bunların iki tarafa borç yükleyen sözleşmeler şeklinde yapılması da olasıdır ${ }^{60}$. Özellikle sözleşmede ortak bir amacın olmadığı durumlarda, sözleşmenin adi ortaklık niteliğinden bahsetmek olanaksızdır. Taraflar arasında böyle bir hukuki ilişki varsa, ölüm halinde aradaki ilişki son bulmayacak, mirasçılarla devam edecektir. Bu nedenle bir devam koşuluna ihtiyaç duyulmayacaktır. Ancak tarafların böyle bir yapı içinde dahi mirasçıların payları devri olasılığına karşı önalım hakkı tanımaları mümkündür. Bu noktada somut olayın koşulları gözetilerek taraflar arasındaki ilişkinin değerlendirilmesi gerekir. Pay sahibi, bu olasılıkta sağlığında yaptığ yaşamlarında kurduğu ilişkinin sonuçlarının devamlılığını sağlamak amacıyla önalım hakkı öngörmüşse, artık söz konusu düzenlemenin sağlar arası bir hukuki işlemin parçası olduğunu kabul etmek gerekir. Örneğin sürekli bir oy anlaşması düzenlenmiş ve önalım hakkı bu çerçevede ölüm sonrasında mirasçıların pay devri olasılığına karşı öngörülmüşse, tarafların sağken öngördükleri düzenin devamlılığını amaçladıkları kabul edilebilir. Burada önalım hakkı tanıyan tarafın doğrudan doğruya terekesini ve mirasçılarını etkileme amacı güdüp gütmediği ortaya konmalıdır. Bir pay sahipleri sözleşmesinde önalım hakkı tanıyan tarafın, bu şekilde bir ölüme bağlı tasarruf yapması, hukukun ona sunduğu olanaklar karşısında alışılmış bir yöntem değildir. Ayrıca, hem sözleşme konusu anonim ortaklık payları hem de önalım hakkının tüm koşulları

\footnotetext{
59 Bu bağlamda bkz Okutan Nilsson (n 6) 80.

60 İsviçre hukukunda, uygulamada, her iki kategoriden unsurlar içeren pay sahipleri sözleşmelerinin olduğu, ancak genelde ortaklıklar hukukuna ilişkin unsurların ağırlıklı olduğu belirtilmiştir [bkz Dieter Haab, 'Der Aktionärbindungsvertrag - Vereinbarung zur Ergänzung des Aktienrechts und Mittel für eine massgeschneiderte Nachfolgeregelung' (2007) (5) ST 383, 383].

${ }^{61}$ Ölüm olgusunun koşuldan ziyade vade teşkil ettiği noktasında bkz Ahmet M Kılıçoğlu, Borçlar Hukuku Genel Hükümler (17th edn, Turhan 2013) 759. Bir hukuki işlemde, ölüm olayının genel olarak öngörülmesi halinde vadenin söz konusu olacağı noktasında bkz Eren, Genel (n 34) 1165. Benzer bir örnek için bkz Rona Serozan, Sağlararası Işslem Yoluyla Ölüme Bağlı Kazandırma (Fakülteler Matbaası 1979) 31.
} 
gerçekleşmişse bu payların bedeli mirasçılara ait olmaktadır. Bu durumda tek mesele, tanınan önalım hakkının belirlenen değeridir. Bunun payların gerçek değerine kıyasla çok düşük belirlenmiş olması, ortada aslında ölüme bağlı bağışlama benzeri bir durum olup olmadığı sorununu gündeme getirir. Öncelikle anonim ortaklık paylarının gerçek değerinin gelecekte hangi durumda olacağının kesin bir şekilde önceden belirlenmesi çok zordur. Önalım hakkına ilişkin sözleşmede belirlenen değerin mirasçıların üçüncü kişilerle anlaştığı değerden ya da payın gerçek değerinden düşük olması durumunda, bunun önalım hakkı sahibi lehine yapılmış ölüme bağlı bir tasarruf amacı taşıdığ1 sonucuna doğrudan ulaşmak makul görünmemektedir. Bu noktada tarafların sağken ulaştıkları sözleşme düzeni ve bunun devamlılığını esas alarak böyle bir düzenleme öngördükleri belirtilebilir. Genelde bu sözleşmeler oluşturulurken taraflar kendi menfaatlerini düşünerek bazı koşulları kabul veya reddederler. Burada taraflar, karşılıklı olarak anonim ortaklığın diğer pay sahiplerine koşula bağlı kazandırıcı haklar tanımak suretiyle doğrudan ya da dolaylı ticari menfaatlerinin güvencesini sağlamaktadır. Yani tanınan bu haklar bir anlamda kendi edindikleri ticari konumun karşıllı̆ını, bir nevi ödemesini teşkil etmektedir. Tarafların sözleşme amacı, ölüm halinde, kendilerine yakın olan kişileri himaye etmek veya onlara iltimas geçmek değildir $^{62}$. Dolayısıyla söz konusu işlem sağlar arası işlem olarak nitelendirilebilir. $\mathrm{Bu}$ durumda işlemin ölüme bağlı tasarrufların şekline bağlı olmayacağı belirtilebilir.

Öğretimizde bir görüşe göre, ölüme bağlı kazandırmayı amaçlayan sağlar arası işlemler atipik bir hukuki yapıya sahiptirler. Ölüme bağlı işlemlerle sağlar arası işlemler arasındaki sınırda kalan bu işlemlerin karma yapısı, onunla uyumlu karma bir hukuki rejimin benimsenmesini gerektirmektedir ${ }^{63}$. Anılan görüşe göre, söz konusu ilişkilere, sağlar arası işlemlere özgü borçlar hukuku kurallarıyla miras hukukunun ölüme bağlı tasarrufa ilişkin kuralları değerlendirilerek uygun düştüğü ölçüde kıyasen bir uygulama yapılmalıdır. Kıyasen uygulamayı öneren ve bu tür hukuki işlemlerin katı bir şekilde kategorize edilmesine karşı çıkan bu görüş de şekil konusunda ölüme bağlı tasarruflara ilişkin kuralların uygulanamayacağını belirtmektedir. Zira bu görüşe göre, söz konusu işlemlerin "ciddi atmosferi" şeklin koruyucu amaçlarını sağlamaktadır ${ }^{64}$. Adi ortaklık niteliği arz etmeyen bir pay sahipleri sözleşmesinin içerdiği önalım hakkı düzenlemesi, bu görüşe göre de şekle tabi olmayacaktır.

Pay sahipleri sözleşmesinde ölümden sonrası için tanınan önalım hakkının kural olarak ölüme bağlı tasarrufların şekline tabi olmayacağını ve bu nedenle kural olarak şekil serbestisinin esas alınacağını belirtebiliriz. Ancak somut olayın koşullarının farklı değerlendirmeyi gerekli kıldığ 1 istisnai durumlarda tarafların ölüme bağlı tasarrufların şekline uygun bir düzenleme yöntemi tercih etmeleri tavsiye olunabilir.

\footnotetext{
62 Ölüme bağlı alım hakkıyla ilgili olarak özellikle bu bağlamda bkz Gloor and Flury (n 7) 305, 311.

63 Bu hususta özellikle bkz Serozan (n 61) 218

${ }^{64} \mathrm{Bu}$ yönde sonuç için bkz ibid 223.
} 


\section{Ortaklık Esas Sözleșmesinde Önalım Hakkı Öngörülmesi}

\section{Sözleşmesel Önalım Hakkının Esas Sözleşmenin Düzenleme Alanını Aşması}

Doğrudan doğruya pay sahipleri arasındaki önalım hakları maddi anlamda esas sözleşme konusu olamaz ${ }^{65}$. Çünkü maddi anlamda esas sözleşme kuralları, nitelikleri gereği, sadece işletmenin sosyal alanına ilişkin olabilirler. Esas sözleşmeler ortaklık ve pay sahipleri arasındaki ilişkiyi düzenler, yoksa salt pay sahipleri arasındaki ilişkileri düzenlemezler. Pay sahiplerinin kendi aralarındaki hak ve yükümlülükleri düzenleyen kurallar, esas sözleşmede değil, sözleşmesel düzeyde ele alınmalıdır ${ }^{66},{ }^{67}$. Daha açık ifade etmek gerekirse, gerçek önalım hakkı, esas sözleşmelerin teorik düzenleme alanıyla bağdaşmaz.

Gerçek önalım haklarına esas sözleşmelerde yer verilememesinin tek nedeni, bunun esas sözleşmelerin teorik düzenleme alanı ile bağdaşmaması da değildir. Pozitif olarak en başta tek borç ilkesi6 ${ }^{68}$ (TTK m 480) bu yönde bir düzenlemeye engeldir ${ }^{69}$. Gerçekten de öğretimize göre, "payların alımı veya satımı zorunluluğunu yükleyen esas sözleşme hükümleri TTK m 480/I ile bağdaşmaz"70. Keza emredici kurallar düzenlemesi (TTK m 340) ile Kanunun öngördüğü bağlam düzenlemeleri haricinde payların serbest devredilebilirlik koşullarını ağıllaştırmayı yasaklayan hüküm (TTK m 493/VII) zikredilen esas sözleşme kurallarının geçersiz olacağını ortaya koyar ${ }^{71}$.

Anonim ortaklık esas sözleşmelerinde ancak bağlam düzenlemeleri önalım hakkıyla benzer bir amaca yönelebilmektedir. Olası bir olayda esas sözleşmesel bağlama uygun bir ret sebebi mevcut değilse, ortaklığın kaçış klozuna dayalı olarak

\footnotetext{
65 Bu bağlamda bkz Kläy (n 15) 488.

66 Bu hususta özellikle bkz ibid 471.

67 Öğretimizde Eski TTK sistemi bakımından, esas sözleşmelerde “...pay sahiplerinin birbirlerine karşı talep (alacak) haklarını içeren borçlar hukuku sözleşmesi niteliğinde olan düzenlemelere de yer verilebileceği..." belirtilmiştir [bkz Erdoğan Moroğlu, ‘Anonim Ortaklık Anasözleşmesi ve Hukuki Niteliği’ Prof. Dr. M. Kemal Oğuzman'ın Anısına Armağan (Beta 2000) 515, 524]. Öğretiden alıntılanan bu tespitten de anlaşıldığı üzere, anılan dönemde dahi, bahsi geçen hususlar esas sözleşmede yer alsa da sözleşmesel düzeyde dikkate alınmaktadır.
}

68 Sadece pay sahipleri sözleşmesinin taraflarını bağlaması gereken önalım ve alım hakkı gibi devir sınırlamalarının esas sözleşmeye konmasının nedeni, çoğunlukla tüm pay sahiplerinin bu düzenlemelerden etkilenmesini sağlamaktır. Hukukumuzda da bu yöndeki esas sözleşme hükümlerinin genel olarak tek borç ilkesine aykırılık nedeniyle tüm pay sahipleri bakımından bağlayıcı nitelik kazanmayacağı ifade edilmektedir [bu yönde bkz Uzel (n 20) 137-138].

69 Önceki TTK sistemi bakımından öğretimizde, teklifte ve icapta öncelik haklarının anonim ortaklık esas sözleşmelerinde düzenlenebileceği ifade edilmiştir. Buna karşın, önalım, alım ve satım haklarının "hem tek borç ilkesine aykırı düştükleri hem de bağlam sisteminin amacını aştıkları için" tüm pay sahiplerini bağlayıcı gerçek bir esas sözleşme hükmü niteliği kazanamayacakları belirtilmiştir [bu yönde bkz Okutan Nilsson (n 6) 249]. Aynı sistem döneminde, esas sözleşmesel önalım haklarının tek borç ilkesine aykırılık oluşturmayacağı da savunulmuştur. Buna göre, zaten anılan düzenlemelerle getirilen borç ve yükümlülükler ortaksal değil yalnızca sözleșmesel bir nitelik taşımaktadır [bkz Bahtiyar (n 8) 83, 95]. Yürürlükte olan hukukumuz bakımından Tekinalp (n 22) 84'te, önalım, alım ve geri alım gibi hakları anonim ortaklık esas sözleşmesinde yer alsalar bile ortaksal nitelik kazanamayacaklarını, bunların borçlar hukukuna özgü olarak kalacaklarını ifade etmektedir.

70 Bkz Tekinalp (n 9) 607 para 859

71 Eski TTK sistemi bakımından esas sözleşmede yer alsa dahi önalım hakkının borçlar hukuku nitelikli olacağı ifade edilmişstir. Buna göre, “...anasözleşmenin ihtiyarî içeriğinde yer alan ve paylar üzerinde önalım hakkına ilişkin olan düzenlemeler, hangi türde olursa olsunlar tamamen borçlar hukuku niteliklidirler" [Bahtiyar (n 8) 83, 91]. 
devri reddetmesi mümkün olur (bkz TTK m 493). Kanuna uygun olması koşuluyla, kaçış klozunun somut kullanımına ilişkin esasların ihtiyaçlara göre esas sözleşme ile düzenlenebilmesi mümkündür ${ }^{72}$. Tabi ki, eşit işlem ilkesi ve payların gerçek değeri üzerinden satın alınması gibi kurallar nedeniyle bu düzenleme alanı ciddi anlamda dar olacaktır. Yukarıda ${ }^{73}$ öğretiye atıfla işaret edilen ve gerçek olmayan önalım hakkı olarak anılan esas sözleşme düzenlemelerinin ancak bu koşullar altında değerlendirilebileceğini ifade edebiliriz ${ }^{74}$. Öğretimizde bir görüşe göre, bir pay sahibinin "-satacağı kişiyi bulmuş olsun veya olmasın- payını satmadan önce diğer pay sahiplerine öneride bulunmasını öngören esas sözleşme" hükümleri geçerlidir ${ }^{75}$. Esas sözleşmede yer alacak bu yönde bir düzenleme, önerilmeye muhatap olma hakkının başka bir türünü teşkil eder ve "ortaksal bir hak gücündedir"’6. Bu görüşe göre, TTK m 493/II'ye hâkim hukuk düşüncesi, anılan yönde bir düzenlemenin bağlayıcıllğına dayanak teşkil etmektedir ${ }^{77}$. Karşıt görüşse, gerçek olmayan önalım haklarına yönelik esas sözleşme hükümlerinin TTK m 493/VII karşısında geçerli olmayacağına işaret etmektedir ${ }^{78}$. Gerçekten de öğretimizde, TTK'nın “yeni bağlam sisteminin niteliği ve devir sınırlamalarının ağırlaştırılması yasağı uyarınca öncelik hakkının kullanımı ile devredenin paylarını satma niyetini mevcut pay sahiplerine bildirmeye zorlanamayacağı" ifade edilmektedir ${ }^{79}$. TTK m 493/VII nedeniyle devir usulünde izlenmesi gereken yeni aşamaların da öngörülemeyeceği savunulmaktadır ${ }^{80}$. Sonuncu görüşün tek borç ilkesine ilişkin TTK m 480/I ve emredici hükümler ilkesine ilişkin m 340 ile de desteklenmesi mümkündür.

\section{Esas sözleşmede Yer Alan Önalım Hakkının Tahvil Yoluyla Sözleşmesel Önalım Hakkı Olarak Değerlendirilip Değerlendirilemeyeceği Sorunu}

Bir esas sözleşmede önalım hakkına yer verilmişse, bunların tahvil yoluyla sözleşmesel önalım hakkı olarak dikkate alınıp alınmayacağı ayrıca değerlendirilebilir. Esas sözleşme hükmünün pay sahipleri sözleşmesi olarak değerlendirilebilmesi istisnai bir olasılıktır. Zira ilgili tarafların, sadece kabul eden pay sahipleriyle sınırlı ve ancak sözleşmesel bir bağlayıcılığı olduğunu bildikleri, karşılıklı bir önalım hakkına onay verip vermeyecekleri sınanmalıdır. Öğretide bu noktada, sözleşme yapma iradesinin

\footnotetext{
Bu hususta bkz Kläy (n 15) 489.

3 Bkz yukarıda II.

74 Eski TTK döneminde, esas sözleşmelerde "öncelikle satın alma hakkı" gibi haklara uygulamada sıkça rastlandığı öğretide belirtilmiştir (bu hususta bkz Moroğlu (n 67) 515, 519).

75 Bkz Tekinalp (n 9) 607 para 860. Yazar, ibid 607 para 859'da, “öneride bulunmak yükümünün” bağlam hükümlerinin müsaadesi oranında geçerli sayılabileceğini de belirtmektedir. Yazara göre, "söz konusu düzenlemeler, bağlam çerçevesinde olmakla birlikte, pay sahiplerinin belirgin bir şekilde ekonomik kayıplarına yol açacaksa..." geçersiz olarak nitelenebilir.

76 Bkz Tekinalp (n 22) 86.

77 ibid 86.

78 Bu yönde bkz Uzel (n 20) 141.

79 ibid 141.

80 ibid 141.
} 
eksikliğinin değil, varlı̆ğının kanıtlanması gerektiği belirtilmektedir. Ayrıca şüphe halinde bağlanma iradesi aleyhine bir sonuca ulaşılmalıdır. Özellikle gerçek değerden sapan devir bedeli ya da eşit işlem ilkesine uygun olmayan düzenlemelerin öngörüldüğü durumlarda buna önemli ölçüde dikkat edilmelidir ${ }^{81}$.

Pay sahipleri arasında önalım hakkı düzenlemesi getiren geçersiz bir esas sözleşme hükmünün tahvil yoluyla borçlar hukuku sözleşmesi olarak dikkate alınması tamamen olanaksız değildir. İstisnaen tüm kurucu pay sahiplerinin açık bir şekilde önalım hakkını kabul ettikleri küçük ortaklıklarda tahvil yoluyla geçersiz olan esas sözleşme hükmünün pay sahipleri arasında bir sözleşme olarak dikkate alınması olanaklıdır. Ancak bu durumda dahi öğretide, kurucu pay sahipleri haricinde bir kişiye sonradan pay devredilmişse, anılan düzenlemenin sözleşmesel hükümlere tahvilinin mümkün olmayacağı belirtilmektedir. Hatta sonradan payı devralmış kişi, önalım hakkını açıkça kabul etse dahi tahvil olanaksız kabul edilmektedir. Çünkü burada da ortak bir sözleşme yapma iradesi olduğundan bahsedilemez. Özellikle mevcut diğer pay sahiplerinin, payı devralan kimseye karşı (önalım hakkının borçlusu olarak) yükümlendiklerine yönelik açılanmış iradeleri bu olasılıkta eksiktir ${ }^{82}$. Önceki TTK bakımından da öğretimizde benzer bir sonuca ulaşılmıştır. Buna göre, söz konusu hakların "...ilk esas sözleşmede yazılı olması halinde tüm kurucu pay sahipleri bu borç sözleşmesi ile bağlı olur" "s3. Esas sözleşme değişikliği ile sonradan pay sahiplerine önalım hakkı tanınırsa, geçersiz olan bu esas sözleşme düzenlemesinin sadece değişikliğe olumlu oy verenler arasında bir pay sahipleri sözleşmesi gibi değerlendirileceği bir an için düşünülebilir. Ancak bunun da çok istisnai olacağını belirtmek gerekir. Olumlu oy veren pay sahipleri, tüm pay sahiplerinin aynı şekilde bağlanacağını düşünerek bu yönde karar vermiş olabilirler. Tüm pay sahiplerinin bağlanmaması halinde, bu kişilerin sözleşme yapmayacakları kabul edilebiliyorsa, ilgili düzenlemenin olumlu oy verenler arasında bir pay sahipleri sözleşmesi olarak ayakta tutulamayacağı öğretide savunulmaktadır ${ }^{84}$.

\section{Hakkı İçeren Sözleşmenin Zorunlu Unsurları}

\section{A. Hakkın Konusu Paylar ve Bunların Bölünememesi}

Önalım hakkı içeren sözleşmeler bakımından BK m 2'ye göre şart olan esaslı unsurlar belirlenmelidir. Önalım sözleşmesinin hukukî niteliğine ilişkin teorilerin sözleşmeye uygulanacak hükümlerin tespitinde satış sözleşmesine yöneldiğini belirtmiştik. BK m 207/I'e göre, satım sözleşmesi taraflarının satım konusu ve bedel ödeme borcu hususlarında anlaşmaları gerekir. Oysa önalım hakkı içeren sözleşmeler

\footnotetext{
Geniş açıklamalar için bkz Kläy (n 15) 490.

82 Söz konusu hususlara ilişkin olarak bkz ibid 490 ve yine aynı yerde dipnot 131 .

83 Okutan Nilsson (n 6) 250.

84 ibid 250. Yukarıda İsviçre öğretisine atıfla belirtildiği üzere, bu durumda sözleşme yapma iradesinin varlığının kanıtlanması gerekir.
} 
bakımından sözleşmenin zorunlu içeriğinin, sözleşme tarafları (önalım hakkı sahibi ve yükümlüsü) ile sözleşme konusu olduğu öğretide belirtilmektedir ${ }^{85}$.

Sözleşmesel önalım hakkında, sözleşmenin konusu, anonim ortaklık paylarıdır. Ancak hakkı tanıyan tarafın paylarının tamamı önalım hakkının konusunu oluşturmayabilir. Hakkın kapsamı, hakkı tanıyan tarafın üçüncü kişilerle devretmek üzere anlaştığı paylardır. Yapılan sözleşmeden farklı bir anlam çıkarılamıyorsa, önalım hakkının devir konusu olan tüm payları kapsadığı kabul edilmelidir. Bu nedenle öğretide, önalım hakkı kullanan kişinin, önceden kararlaştırılmış ya da belirlenecek olan fiyat üzerinden teklif konusu tüm payları devralmaya hazır olması gerektiği ifade edilmektedir. Önalım hakkı bölünmeksizin (bir bütün olarak) kullanılabilir ${ }^{86}$. Önalım hakkının bölünmeden kullanılmasına yönelik ilkenin özellikle adi ortaklık niteliği taşıyan pay sahipleri sözleşmelerinde, paylarının tamamını devretmek isteyen pay sahibini koruyucu etkisi vardır. Önalım hakkının konusuyla hakkın kullanılması arasında anılan ilke nedeniyle önemli bağlantılar vardır ve aşağıda bunlara ayrıca değinilecektir.

Önalım hakkı, satıma sunulan münferit bazı paylar ya da bunların bir kısmı üzerinde kullanılabilecek şekilde de düzenlenebilir ${ }^{87}$. Başka bir ifadeyle önalım hakkının bölünmeksizin kullanılmasına yönelik ilkeden sözleşmeyle vazgeçilebilir. Bunun tam tersi de mümkündür. Taraflar kendi aralarında sözleşme konusu yaptığ 1 payların tamamını satışa sunma yükümlülüğü altına da girebilir. Öğretide böylelikle taraflardan birisinin çok az bir payla sözleşmede kalmasının ve oy birliği gerektiren durumlarda veto hakkı kullanarak diğer sözleşme taraflarını bloke etmesinin engellenebileceği belirtilmektedir ${ }^{88}$. Öğretideki bu tespit özellikle adi ortaklık niteliği taşıyan pay sahipleri sözleşmeleri içinde yer verilen önalım hakkı bakımından çok yerindedir ${ }^{89}$. Bu şekildeki olası bir düzenleme en baştan taraflar arasında oluşturulan sistemin işlerliğini garanti eder.

\section{B. Bedel}

\section{Sınırlandırılmamış Önalım Hakkı}

Önalım hakkı içeren sözleşmelerde, önalım hakkı konusunun belirlenmesi yeterlidir. $\mathrm{Bu}$ anlamda, bedel ödeme borcu esaslı nokta (bkz BK m 2) teşkil etmez. Çünkü pay

\footnotetext{
Bu hususta bkz Müller and Biedermann (n 7) 893. Benzer olarak bkz Demirbaş (n 28) 249, 256. Fischer (n 6 ) 63 ’te, önalım bedelini de esaslı unsurlar içinde saymıştır. Önalım bedelini sözleşmenin esaslı unsurlarından birisi olarak saymamamızın nedeni aşağıda açıklanmıştır.

86 Bu bağlamda özellikle bkz Forstmoser and Küchler (n 7) 380 para 1201-1202.

87 ibid 380-381 para 1203.

88 Bu bağlamda ibid 381 para 1204.

${ }^{89}$ Gerçekten de BK m 625/II'de yönetici ortakların olumsuz yönetme hakkı düzenlenmiştir. Buna göre, ortaklığı yönetmeye yetkili olan ortaklar bir işlemin tamamlanmasından önce yapılacak işleme itiraz ederek bu işlemin yapılmasın engelleyebilmektedir. Çok az bir payla pay sahipleri sözleşmesinde kalmasına izin verilen ortak, bu şekilde sistemi bloke edebilme olanağını tutmaya devam edecektir.
} 
üzerindeki sözleşmesel önalım hakkına BK m 241/III kıyasen uygulanabilir. Taraflar önalım hakkına konu olan payları belirleyip, bedel ödeme borcu hakkında herhangi bir belirleme yapmayabilirler ${ }^{90}$. Buna göre, sözleşmede herhangi bir düzenleme yapılmadıysa, bedel ödeme borcu, devredenin üçüncü kişiyle yaptığı sözleşmedeki bedele göre tespit edilecektir. Çalışma kapsamında BK m 241/III değerlendirilirken özellikle bedel ödeme borcu merkeze alınmıştır. Fakat söz konusu hükmün sadece "satış bedeli tutarını değil, diğer sözleşme modalitelerini”"91 de kapsadığı önemle belirtilmelidir.

Önalım hakk1, satım bedelinin belirlenmesi türüne göre ikiye ayrılır. Sınırlandırılmamış önalım hakkında, taraflar sözleşmede bedeli belirlemezler. Bu durumda BK m 241/III kıyasen uygulama alanı bulur. Payları devralacak olan üçüncü kişinin önalım yükümlüsüne ödemeye hazır olduğu bedel, önalım bedeli olarak kabul edilir ${ }^{92}$. Sınırlandırılmamış önalım hakkının paylarını devretmek isteyen kişi bakımından olumlu olduğu öğretide belirtilmektedir. Zira önalım hakkının kullanılmasından çekinmesine gerek yoktur. Aksine, paylarını almaya hazır üçüncü kişiye devredebileceği en yüksek bedelden payları devredebilir ${ }^{93}$. Bu noktada kabul edilen sistemin MK m 2'ye aykırı bir şekilde üçüncü kişilerle anlaşılmak suretiyle fiyat belirlenebilmesine çok müsait olduğunu belirtmek gerekir. Dolayısıyla olası uyuşmazlıklarda üçüncü kişilerle yapılan devir sözleşmelerinin fiyat unsurunun bu bakımdan özellikle değerlendirilmesi önem taşır.

\section{Sınırlandırılmıs Önalım Hakkı}

Sınırlandırılmış önalım hakkında, taraflar önalım sözleşmesinde doğrudan satım bedelini veya satım bedelinin belirlenmesi usulünü kararlaştırır ${ }^{94}$. Payını devretmek isteyen tarafin üçüncü kişiyle yaptığı devir sözleşmesinin, önalım sözleşmesinde belirlenen bedel üzerinde etkisi olmaz ${ }^{95}$. Öğretide, sınırlandırılmış önalım hakk1, sözleşmede kararlaştırılan bedel belirleme usulüne göre, mutlak veya nispi olarak ayrıma tabi tutulmaktadır.

\footnotetext{
Bu bağlamda İsviçre hukuku açısından bkz Vischer (n 3) 82, 83; Müller and Biedermann (n 7) 893. Hukukumuz açısından benzer olarak bkz Eren, Özel (n 32) 203.

91 Bkz Gümüş (n 44) 435, 446.

92 Sınırlandırılmamıș önalım hakkı kavramıyla ilgili olarak bkz Forstmoser and Küchler (n 7) 377 para 1187; Vischer (n 3) 82, 84; Germann (n 6) 696 para 1620; Müller and Biedermann (n 7) 893; Hintz-Bühler (n 4) 92; Fischer (n 6) 63. Anonim ortaklıklar hukukumuz açısından sınırsız ve sınırlı önalım hakkı kavramları için bkz Okutan Nilsson (n 6) 218 dipnot 338339; Bahtiyar (n 8) 83, 90. Borçlar hukukumuzda sınırlandırılmış önalım hakkı, nitelikli; sınırlandırılmamıș önalım hakkı da olağan önalım hakkı olarak anılmaktadır [bkz Demirbaş (n 28) 249, 254; Gümüş (n 44) 435, 446; Eren, Mülkiyet (n 32) 432; Eren, Özel (n 32) 199; Zevkliler and Gökyayla (n 28) 69]. Keza adi-mevsuf, limitli-limitsiz, belirli-belirsiz önalım hakkı gibi tabirler de kullanılmaktadır [bkz Aydoğdu and Kahveci (n 8) 285].

93 Bu hususta bkz Forstmoser and Küchler (n 7) 377 para 1188.

94 Bu yönde ibid 378 para 1189; Fischer (n 6) 63.

95 Bu bağlamda bkz Hintz-Bühler (n 4) 92.
} 
Alım bedelinin rakamsal olarak kararlaştırıldığı veya rakamsal bir şekilde kesin olarak belirlenebilir olduğu durumlarda ${ }^{96}$, mutlak sınırlandırılmış önalım hakkından bahsedilir ${ }^{97}$. Böylece, ileride ödenecek bedel, hakkın tanınması sırasında tespit edilir ve gelecekteki fiyat artmalarına karşı önlem alınmış olur ${ }^{98}$. Bu şekilde, bir bedel belirlenmesi, pay değerinde olması muhtemel değişiklikleri dikkate almamaktadır. Payın değerinde olması muhtemel değişimlerin taraflar açısından önemli olduğu durumlarda böyle bir usulün kullanılmamasında büyük fayda vardır.

Sözleşme sadece fiyat belirleme usulüne yönelik bir düzenleme yaptıysa, nispi sınırlandırılmış önalım hakkı söz konusu olur. Örneğin, sözleşmede bir üst sınır teşkil etmek üzere fiyat belirlenir. Önalım hakkı yükümlüsünün üçüncü kişiyle yaptığı anlaşmada belirlenen fiyat bundan düşükse, hak sahibinin bu fiyattan hakkını kullanabileceği kararlaştırılabilir ${ }^{99}$. Keza, payların gerçek değerini veya gerçek değerine göre belirlenecek bir değeri esas alan hükümlere sözleşmelerde yer verilebilir ${ }^{100}$. Nispi anlamda sınırlandırılmış önalım hakkı konusunda farklı usullere rastlamak mümkündür. Söz konusu usuller tarafların anılan hususta sözleşme yaparken güttükleri amaca göre şekillenir. Nispi anlamda sınırlandırılmış önalım hakkı düzenlenirken, tarafların, bedelle ilgili karara esas alınacak unsurlarla birlikte, karar alma usulünü ve söz konusu kararı alacak kişileri belirlemeleri gerekir $^{101}$.

Sözleşmede, önalım bedelinin üçüncü bir kişi tarafından saptanacağı kararlaştırılabilir. Üçüncü kişi, tarafların güvendiği birisi ya da bir uzman olabilir. $\mathrm{Bu}$ usulde, ortaklık ve pay sahipleri sözleşmesi taraflarının bedel belirleme sürecine etki edememesi amaçlanır ${ }^{102}$. Fiyatın belirlenmesi üçüncü kişinin serbest takdirine bırakılabileceği gibi, üçüncü kişinin fiyat belirlemede uyması gereken bazı temel koşullar da tespit edilebilir. Fiyat belirleme yöntemi olarak bu usul seçildiyse, çıkabilecek olası uyuşmazlıklar dikkate alınarak, üçüncü kişinin masraflarının nasıl karşılanacağının da düzenlenmesi gerekmektedir ${ }^{103}$. Önalım hakkını düzenleyen sözleşmede, bedelin taraflar arasında pazarlıkla tespit edileceği de kararlaştırılabilir. Pazarlık usulünde, pazarlık görüşmelerinin üçüncü bir kişi tarafindan yönetileceği de öngörülebilir ${ }^{104}$.

\footnotetext{
6 Örneğin payların değerinin itibari değerine oranla belirlenmesi böyledir.

97 Bkz Forstmoser and Küchler (n 7) 378 para 1190.

98 Bu bağlamda bkz Aydoğdu and Kahveci (n 8) 278.

99 Bu hususta bkz Forstmoser and Küchler (n 7$) 378$ para 1191

100 Bu bağlamda bkz Hintz-Bühler (n 4) 92; Forstmoser and Küchler (n 7) 378 para 1191.

101 Bu hususta ibid 379 para 1195

102 Bu yönde ibid 379 para 1195.

103 Son iki hususla ilgili olarak bkz Hintz-Bühler (n 4) 93.

104 Bu bağlamda bkz Forstmoser and Küchler (n 7) 379 para 1195.
} 


\section{Haktan Yararlanmanın Önkoşulu: Önalım Olayı}

\section{A. Önalım Olayının Belirlenmesi}

\section{BK m 240/I'in Kıyasen Uygulanması ve Sözleşmeyle Belirleme}

Önalım olayı, hakkı kullanmanın önkoşuludur. Hakkın kullanımını mümkün kılan olaya önalım olayı denmektedir ${ }^{105}$. Önalım olayının değerlendirilmesinde taşınmazlara ilişkin BK m 240/I kıyasen ${ }^{106}$ uygulanabilir. Buna göre, "önalım hakk1, taşınmazın satışı ya da ekonomik bakımdan satışa eşdeğer her türlü işlemin yapılması hâllerinde kullanılabilir”. Keza BK m 240/II'ye göre, önalım hakkına konu payın miras olarak bırakılması, cebri artırma yoluyla satış1, kamu hizmetlerinin yerine getirilmesi ve bunlara benzer amaçlarla edinilmesi hâlleri BK m 240/I anlamında "satış ya da satışa eş değer" işlem olarak kabul edilmemektedir ${ }^{107}$. Yani bu hallerde önalım olayı gerçekleşmiş olmadığından, hak da kullanılamaz. Bu sayım sınırlayıcı bir sayım değildir ${ }^{108}$. Bu nedenle payın pay sahibinin iradesi dışında devrinin söz konusu olduğu hallerde önalım olayının kural olarak gerçekleşmeyeceği borçlar hukuku öğretimizde kabul edilmektedir ${ }^{109}$.

BK m 240, önalım sözleşmeleri bakımından emredici değildir. Bu nedenle taraflar, önalım olayını sözleşme ile daha detaylı ya da Kanundan farklı şekilde düzenleyebilirler. Özellikle olası uyuşmazlıkların daha baştan engellenebilmesi için önalım olayıyla ilgili açıklayıcı ve hatta bu alanı genişletici bazı sözleşmesel düzenlemeler yapmakta fayda vardır. Bu bağlamda, normalde önalım hakkının kullanılmasına mahal vermeyecek durumlar, sözleşmeyle önalım olayı oluşturacak şekilde düzenlenebiliri10. Örneğin, bağışlama Kanunun aradığ şekilde önalım hakkı kullanılmasına olanak sağlayan bir işlem değildir. Fakat taraflar hakkın kullanılma alanını bağışlamaları da kapsayacak şekilde genişletebilirler. Sözleşmesel düzenlemeler önalım hakkının kullanılma alanının belli ölçüde daraltılması şeklinde de olabilir. Örneğin belli yakınlıktaki kişilere (eş ve altsoy gibi) veya yavru ortaklıklara, özellikle sözleşme taraflarından birisinin hâkim konumda olduğu bir

\footnotetext{
${ }_{05}$ Bu hususta bkz Eren, Mülkiyet (n 32) 439. Yazar burada önalım olayı olarak adlandırılan hususu "önalım olgusu" olarak adlandirmaktadır.

106 BK m 240/I düzenlemesinin, taşınır eşya, alacaklar ve anonim ortaklık payları bakımından kıyasen uygulanabileceği hususunda İsviçre hukuku açısından bkz Forstmoser and Küchler (n 7) 387 para 1234. Benzer olarak bkz Hintz-Bühler (n 4) 97; Germann (n 6) 696-697 para 1621. İlgili hükmün İsviçre karşıllı̆ı olarak öngörülen OR m 216c gerekçesinde de bu düzenlemenin taşınırlar ve anonim ortaklık payları bakımından uygulanacağı yönünde bkz Fischer (n 6) 63. Ayrıca TTK m 1 ile MK $m 5$ bağlantısı da kıyasen bir uygulamayı olanaklı kılmaktadır.

107 Bu husus önceki BK ve TTK döneminde de kabul edilmekteydi [bu bağlamda bkz Okutan Nilsson (n 6) 218-219].

108 BK m 240'a ilişkin olarak bu yöne bkz Gümüş (n 44) 435, 439.

109 Taşınmazlar bağlamında bu yönde bkz Kizir (n 28) 1773, 1785.

110 Bu hususlarda bkz Forstmoser and Küchler (n 7) 388 para 1236; Fischer (n 6) 63. Hukukumuzda taşınmazlar açısından sözleşmesel önalım hakkında önalım olayının taraflarca genişletilip daraltılabileceği ifade edilmiştir. Fakat özellikle önalım olayının sözleşmeyle genişletilmesinin taşınmazlar bakımından bazı sonuçları olabileceğine dikkat çekilmiştir [bkz Gümüş (n 44) 435, 442-443].
} 
ortaklığa yapılan devirlerin hakkın kapsamı dışında bırakılması düşünülebilir ${ }^{111}$. Keza pay sahipleri sözleşmesinin tarafları kendi aralarında yapılan devirleri veya kendi aile bireylerine yapılan devirleri bu kapsamın dışında bırakabilirler ${ }^{112}$. Sözleşmelerle yapılacak düzenlemeler, olası kötüye kullanmalar da değerlendirilerek kaleme alınmalidir.

\section{Satışa Eşdeğer İşlemler}

\section{a. Genel Ölçütler ve Özel Durumlar}

\section{aa. Genel Ölçütler}

Sözleşmeden doğan önalım hakkının kullanılmasına meydan veren en tipik hukukî işlem satım sözleşmesidir ${ }^{113}$. Ancak, BK m 240'ta geçen satışa eş değer işlem ifadesinin somutlaştırılması, olası uyuşmazlıkların çözümü bakımından daha önemlidir. BK m 240'ın satış yanında ekonomik anlamda satışa eşdeğer işlemleri önalım olayı olarak ifade etmesi, hak sahibi lehine bir düzenlemedir ${ }^{114}$. $\mathrm{Bu}$ noktada, somut olayın özellikleri dikkate alınarak yorum yoluyla sonuca ulaşılması gerektiği borçlar hukuku öğretimizde belirtilmektedir ${ }^{115}$. BK m 240/ II değerlendirildiğinde, satışa eş değer bir işlemin öncelikle iradî bir devir işlemi olması gerektiği belirtilmelidir ${ }^{116}$. Bu nedenle $\mathrm{BK}$ m 274 bağlamında payın iradi olarak açık artırmaya çıkarılması önalım hakkının kullanılması bakımından gerekli koşulu sağlar ${ }^{117}$. Önalım olayının gerçekleşmesi bakımından sözleşmenin yapılması yeterlidir. Ayrıca ifa edilmiş olması gibi bir koşul aranmaz ${ }^{118}$. Bu nedenle payın devrine ilişkin borçlandırıcı işlemin yapılması, önalım olayını gerçekleştirir. Buna karşın önalım konusu payın satımına ilişkin üçüncü kişilerle yapılan müzakereler, önalım olayı kapsamında değerlendirilemez ${ }^{119}$. Bunun yanında pay ivazlı olarak devredilmeli ve geçişi cüz'i intikal teşkil etmelidir' ${ }^{120}$. Yani ivazsız el değiştirmeler bu kapsamda anılamaz. Örneğin, payın bağışlamaya konu olması, "satışa eş değer”

\footnotetext{
111 İsviçre hukukunda bu tür kayıtlara sıklıkla rastlandığı yönünde bkz Forstmoser and Küchler (n 7) 388 para 1238.

112 Bu yönde örnekler için ayrıca bkz Okutan Nilsson (n 6) 214-215.

113 Bkz Eren, Mülkiyet (n 32) 439; Eren, Özel (n 32) 207.

114 Bkz Demirbaş (n 28) 249, 257.

115 Bkz Kizir (n 28) 1773, 1784.

116 Bkz Germann (n 6) 697 para 1622; Fischer (n 6) 64; Yavuz, Acar and Özen (n 8) 255; Eren, Özel (n 32 ) 207.

117 Bu yönde bkz Hintz-Bühler (n 4) 97. Borçlar hukuku öğretimizde de aynı sonuca ulaşılmaktadır [bu hususta Kizir (n 28) 1773, 1784; Eren, Mülkiyet (n 32) 441; Eren, Özel (n 32) 209; Zevkliler and Gökyayla (n 28) 70; Feyzi N Feyzioğlu, 'Şuf'a Hakkının Kullanılması Mümkün Olan ve Olmayan Tasarruflar' (1953) 19 (1-2) İ̈HHFM 222, 242].

118 Bkz Demirbaş (n 28) 249, 257; Eren, Özel (n 32) 209.

119 Sözleşmenin geçerli bir şekilde yapılması gereğinin ardında yatan iki neden olduğu öğretide aktarılmaktadır. Bunlardan birisi önalım hakkının kullanılmasında emniyet sağlaması, diğeri de bu yaklașımın önalım hakkı sahibini koruduğu değerlendirmesidir [bu hususta Meier Hayoz and Doğanay (n 33) 273, 284].

120 Bu yönde Fischer (n 6) 64. Hukukumuzda bu bağlamda bkz Eren, Mülkiyet (n 32) 439. İvazlılık noktasında ayrıca bkz Aydoğdu and Kahveci (n 8) 277; Yavuz, Acar and Özen (n 8) 255.
} 
işlem çerçevesinde değerlendirilemez ${ }^{121}$. Öğretide haklı olarak karma bağışlamalarla ilgili peşinen bir sonuca ulaşılamayacağı belirtilmektedir. Kendisine pay devredilen üçüncü kişinin şahsi sebeplerle karşılıksız olarak bu bağışlamanın tarafı olması halinde, önalım olayının gerçekleşmeyeceği ve kullanılamayacağı belirtilmektedir. Buna karşın bağışlama unsurunun sadece yan edim özelliği taşıdığı ya da kanunu dolanma amacında olduğu bir durum söz konusuysa sorun farklı değerlendirilir ve önalım olayının gerçekleştiği kabul edilir ${ }^{122}$. Borçlar hukuku öğretimizde de karma bağışlama açısından benzer sonuçlara ulaşılmıştır. Buna göre: karma bağışlamalarda, bağışlamadan çok satış ön planda ise önalım olayı vardır; bağışlama ön planda ise önalım olayı yoktur. Ancak taraflar arasında bedelin çok düşük tespit edildiği durumlarda önalım hakkı sahibi malın objektif değerini ödemek suretiyle önalım hakkını kullanabilmelidir ${ }^{123}$.

Karşı edimin asli olarak üçüncü kişinin şahsıyla bağlantılı olmaması gerekir ${ }^{124}$. Örneğin, payın ölünceye kadar bakma sözleşmesinin bir parçası olması halinde bu hakkın kullanılamayacağı belirtilmektedir. Öğretide payın sermaye olarak bir ortaklığa getirilmesinin de hakkın ön koşulunu oluşturmayacağı belirtilmektedir ${ }^{125},{ }^{126}$. Burada ortaklık sözleşmesinde edimlerin satım sözleşmesi gibi bir karşıllıklılık (synallagma) içinde olmaması görüşe gerekçe olarak gösterilebilir. Keza mal rejimi nedeniyle gerçekleşen devirler de satışa eş değer olarak kabul edilemez. Buna karş111k, öğretimizde, "önalım yükümlüsünün üçüncü kişiye olan para borcunu ödemek amacıyla" önalım hakkı konusu payı o kişiye devretmesi satışa eş değer işlem olarak nitelenmektedir ${ }^{127}$.

Üçüncü kişiyle yapılan sözleşme, mülkiyet devrine yönelik ve geçerli olmalıdır ${ }^{128}$. $\mathrm{Bu}$ nedenle öğretide, pay üzerinde intifa ya da rehin hakkı kurulması BK m 240/I

121 Bu bağlamda bkz Forstmoser and Küchler (n 7) 387 para 1234. Bağışlama noktasında taşınmazlar açısından hukukumuzda bkz Gümüş (n 44) 435, 441; Demirbaş (n 28) 249, 258; Eren, Mülkiyet (n 32) 442.

$122 \mathrm{Bu}$ anlama gelmek üzere bkz Hintz-Bühler (n 4) 97-98. Hukukumuzda taşınmazlar açısından benzer olarak bkz Eren, Mülkiyet (n 32) 443; Eren, Özel (n 32) 211 ve özellikle aynı yerde dipnot 119.

123 Bkz Kizir (n 28) 1773, 1784 dipnot 47. Yine benzer olarak bkz Gümüş (n 44) 435, 441; Feyzioğlu, 'Hakkın Kullanılması' (n 117) 222, 247.

124 Bu bağlamda bkz Hintz-Bühler (n 4) 98. Germann (n 6) 697 para 1622'de "ivazın, alıcının şahsına ilişkin olmaması, parasal bir edim olması gerektiğini belirtmektedir”. Buradan karşı edimin salt para borcu olması gerektiği gibi bir sonuca ulaşmak, hakkın kullanım olană̆ını ciddi anlamda daraltır. Ekonomik anlamda satım sonucu doğuran işlemler önalım olayı bakımından yeterli kabul edilmelidir.

125 Son iki hususla ilgili olarak bkz Hintz-Bühler (n 4) 98. Yazar bunu gerekçelendirmemiştir.

126 Hukukumuzda eski MK döneminde, taşınmazın bir ortaklığa sermaye olarak getirilmesi halinde taşınmaz üzerindeki önalım hakkının kullanılamayacağını belirtmektedir [bkz Feyzi N Feyzioğlu, Şuf'a Hakkı (Fakülteler Matbaası 1959) 260]. Yazar aynı yerde ve Feyzioğlu, 'Hakkın Kullanılması' (n 117) 222, 256'da bunun nedenini, aksi halde, birçok kişinin ortaklıklara ortak olarak girme imkânından mahrum kalacağı ve ortaklıkların da sermaye tedarikinde güçlüklerle karșılaşacağ açılamaktadır. Keza BK m 239'un gerekçesinde bir taşınmazın limited ya da anonim ortaklığa aynî sermaye olarak getirilmesinin önalım hakkı kullanılmasına mahal vermeyeceği belirtilmiştir. Taşınmazlar bakımından aynı hususta bkz Kizir (n 28) 1773, 1785; Aydoğdu and Kahveci (n 8) 283; Eren, Mülkiyet (n 32) 443; Zevkliler and Gökyayla (n 28 ) 70. Keza aynı yönde bkz Meier Hayoz and Doğanay (n 33) 273, 282.

127 Taşınmazlarla ilgili olarak, ifa yerini tutan eda hakkında bu yönde bkz Kizir (n 28) 1773, 1784.

128 Bkz Germann (n 6) 697 para 1622; Fischer (n 6) 64. 
çerçevesinde "satışa eş değer" işlem olarak kabul edilmemektedir ${ }^{129}$. Kural bu olmakla birlikte, hukukun ekonomik analizi çerçevesinde, pay üzerinde kurulan intifa hakkının mülkiyetin devrine yakın sonuçlar doğurabiliyor olması göz önünde tutulmalıdır. Bu nedenle pay üzerinde intifa hakkı tesis edilen durumlarda ekonomik bir el değiştirmenin amaçlanıp amaçlanmadığı dikkatle incelenmelidir ${ }^{130}$. Gerçekten de örneğin TTK m 492/II'de olduğu gibi intifa hakkının devre eşdeğer kabul edildiği durumlar söz konusu olabilmektedir. İntifa hakkı kurulmasının özelikle önalım olayının gerçekleşmesini engelleme amacı taşıdığı durumlarda, aşağıda ayrıca işaret edilen çözümlere yönelmenin mümkün olduğunu düşünmekteyiz.

BK'nın 239. maddesinin gerekçesi olarak, taşınmazlar üzerinde tesis edilen önalım hakkına ilişkin bir örnek verilmiştir. Buna göre, "bir gayrimenkul yatırım ortaklığına ait hisselerin, bütünüyle devri halinde bu işlem, fikra anlamında ekonomik bakımdan satışa eşdeğer işlem niteliğinde sayılabilecektir" ${ }^{\prime 31}$. Aynı örnekten hareketle hisse ticaretiyle uğraşan bir anonim ortaklık paylarının tamamının devrinin ortaklık malvarlığında bulunan hisseler bakımından önalım olayı oluşturup oluşturmayacağı sorgulanabilir. Her iki örnekte de önalım sözleşmesinin konusunu oluşturan taşınmaz veya ortaklık hissesinin mülkiyetinin nakline yönelik doğrudan bir sözleşme yoktur. İlgili pay veya taşınmazın sahibi hâlâ aynı anonim ortaklıktır. Sadece bu anonim ortaklığın pay sahipleri değişmektedir. Bu durumda önalım konusunun devrine yönelik doğrudan bir mülkiyet nakli olmadığından ilgili örnek dikkatle değerlendirilmelidir. Kanımızca burada somut olayın koşulları çerçevesinde yapılan işlemin önalım olayının gerçekleşmesini engelleme amacı taşıyıp taşımadığı değerlendirilmelidir. Eğer önalım olayının engellenmeye çalışılması söz konusuysa bununla ilgili olarak aşağıda yapılan açıklamalara uygun bir sonuca ulaşmak gerekir ${ }^{132}$. Ulaşılamıyorsa, önalım olayının gerçekleşmediği ve hakkın kullanılamayacağı kabul edilebilir. Zira aksi yönde bir yaklaşım tüzel kişilik kavramını yok saymak olur.

\section{bb. Özel Durumlar}

\section{aaa. BK m 241/II Düzenlemesi ile Geçersiz ve İptal Edilebilir İşlemler}

BK m 241/II’ye göre, “önalım hakkı kullanıldıktan sonra satış sözleşmesi ortadan kaldırılırsa ya da alıcının şahsından kaynaklanan sebeplerle onaylanmazsa, bu durum önalım hakkı sahibine karşı ileri sürülemez". Hüküm uyarınca alıcı ve satıcının arasındaki sözleşmenin ortadan kaldırılması, BK m 132'ye uygun bir ibra sözleşmesi,

\footnotetext{
29 Bu hususta bkz Forstmoser and Küchler (n 7) 387 para 1234. Taşınmazlar üzerinde intifa hakkı açısından bu bağlamda bkz Eren, Mülkiyet (n 32) 443; Eren, Özel (n 32) 211.

130 Taşınmazlarda bu hususa ilişkin olarak özellikle bkz Gümüş (n 44) 435, 440; Aydoğdu and Kahveci (n 8) 288. Keza yine taşınmazlar bakımından üst hakkı kurulmasıyla ilgili olarak bkz Demirbaş (n 28) 249, 257.

131 Örnek açısından ayrıca bkz Kizir (n 28) 1773, 1784; Aydoğdu and Kahveci (n 8) 283; Zevkliler and Gökyayla (n 28) 70.

132 Taşınmazlara ilişkin olarak İsviçre öğretisinde bir görüşün madde gerekçesinde anılan durumda önalım olayının gerçekleşmesini reddettiği de öğretimizde ifade edilmiştir [bkz Gümüş (n 44) 435, 441].
} 
temerrüte ilişkin BK m 125 veya ayıptan sorumluluğa ilişkin BK m 227'de yer verilen dönme gibi hukuki kurumları ifade etmektedir. Bu durumda önalım hakkı kullanılana kadar satıcı ve alıcı örneğin BK m 132 uyarınca aralarındaki sözleşmeyi anlaşarak kaldırabilirler. Önalım hakkı kullanıldıktan sonra alıcı ve satıcının bu yola başvurması hakkın geçerli olarak kullanılmış olmasını engellemez ${ }^{133}$. Keza anılan hükme göre, satış sözleşmesi "alıcının şahsından kaynaklanan sebeplerle onaylanmazsa” bu da önalım hakkı sahibine karşı, hak kullanıldıktan sonra ileri sürülemez. Fakat satıcının şahsından kaynaklanan sebeplerle satışın onaylanmamasının hükmün kapsamında olmayacağı değerlendirilmektedir. Hüküm aslen, ayırt etme gücüne sahip küçük ya da kısıtlının kendisini borç altına sokan hukuki işlemi kanunî temsilcinin rızası olmadan yapması halinde uygulanmaktadir ${ }^{134}$.

BK m 241/II düzenlemesinin, özellikle geçersiz ve iptal edilebilir işlemlerin etkilerini düzenlemediği belirtilmektedir ${ }^{135}$. Geçersiz satış sözleşmesi, kural olarak önalım olayı teşkil etmez ${ }^{136}$. Bu nedenle geçersiz bir satış sözleşmesi nedeniyle hakkın kullanılması halinde, kullanıma yönelik irade beyanının etki doğurmayacağı ve önalım hakkının varlığını koruyacağı öğretide belirtilmektedir ${ }^{137}$. Ancak tek taraflı bağlamazlığın söz konusu olduğu haller bakımından ayrım yapılmaktadır. Tek taraflı bağlamazlık ve özellikle iptal edilebilirliğin ${ }^{138}$ söz konusu olduğu satım sözleşmelerinin ilk başta önalım olayını oluşturduğu ifade edilmektedir ${ }^{139}$. İşlemin iptaliyle birlikte önalımın da düşeceği belirtilmektedir ${ }^{140}$. Bu durumda hakkın kullanılması bakımından en başta bir sorun yoktur. Ancak söz konusu satım sözleşmesi iptal edildikten sonra, hakkın kullanımına yönelik beyan da geçmişe etkili olarak ortadan kalkacaktır ${ }^{141}$.

\footnotetext{
33 Anılan yönde bkz Markus Binder, 'Art 216-221 OR' in Markus Müller-Chen and Claire Huguenin (eds), Vertragsverhältnisse Teil 1: Innominatkontrakte, Kauf, Tausch, Schenkung, Miete, Leihe (Art. 184 - 318 OR), CHK - Handkommentar zum Schweizer Privatrecht (Schulthess 2016) Art 216d para 5. Hukukumuzda sadece ikale sözleșmesi bağlamında aynı yönde bir değerlendirme için bkz Kizir (n 28) 1773, 1788. İsviçre öğretisine atıfla bu yönde iki görüş olduğu ve bir görüşün sadece ikale sözleşmesini bu hüküm bağlamında kabul ettiği, diğerininse ayıplı ifa nedeniyle dönme hakkının kullanılması gibi halleri de hüküm içinde değerlendirdiği noktasında bkz Gümüş (n 44) 435, 446. Sonuncu ile benzer yönde bkz Demirbaş (n 28) $249,259-260$.

134 Taşınmazlar açısından bu yönde Kizir (n 28) 1773, 1788. Bu hususta ayrıca bkz Demirbaş (n 28) 249, 260.

135 Bu manada Binder (n 133) Art 216d para 6; Atteslander-Dürrenmatt (n 28) Art 216d para 5.

136 İlgili olarak bu yönde bkz Binder (n 133) Art 216d para 7; Atteslander-Dürrenmatt (n 28) Art 216d para 5. Öğretimizde de bu durum şu şekilde ifade edilmiştir: "Resmi şekle aykırı, muvazaalı ya da ehliyetsiz bir kişi tarafindan yapılan ya da hukuka, ahlaka aykırı veya imkânsız olan satış sözleşmelerinde, ortada geçerli bir sözleşme olmadığ için önalım olayı gerçekleşmiş sayılmaz" [bkz Demirbaş (n 28) 249, 258]. Baştan itibaren geçersizlik hallerinde önalım hakkının kullanılamayacă̆ yönünde ayrıca bkz Aydoğdu and Kahveci (n 8) 284.

137 Pay devriyle ilgili olarak bu yönde bkz Hintz-Bühler (n 4) 99.

138 Hukukumuzda herhangi bir ayrım yapılmaksızın, iradeyi sakatlayan sebeplerden birisinin varlığı nedeniyle geçersizlik halinde önalım hakkının ileri sürülemeyeceği hususunda bkz Demirbaş (n 28) 249, 260.

139 Bu bağlamda bkz Binder (n 133) Art 216d para 8; Atteslander-Dürrenmatt (n 28) Art 216d para 5.

${ }_{140}$ Bu bağlamda bkz ibid Art 216d para 5. Hukukumuzda, irade sakatlıkları, gabin veya sözleșmeden dönme gibi bir nedenle satış sözleşmesinin, önalım hakkı kullanıldıktan sonra ortadan kaldırılması halinde BK m 241/II'nin uygulanması gerektiği ve bu durumun önalım hakkı sahibine karşı ileri sürülemeyeceği de savunulmaktadır [bkz Aydoğdu and Kahveci (n 8) 285].

141 Tespite ilişkin olarak bkz Hintz-Bühler (n 4) 99.
} 


\section{bbb. Bağlamlı Nama Yazılı Paylarda Ortaklığın Devre Onay Vermemesi}

Önalım olayının oluşup oluşmadığının tespitinde, özellikle halka açık olmayan anonim ortaklıkların bağlamlı payları nedeniyle sorunlarla karşılaşmak olasıdır. Ortaklık pay devrini haklı olarak reddetmişse, ortaklık kararından önce kullanılmış olan önalım hakkının durumu değerlendirilmelidir.

Bağlamlı nama yazılı payların devrinde, ortaklığın devre onay vermemesinin devreden ve devralan arasındaki hukukî ilişkiye etkisi tespit edilmelidir. Pay devri konusu çalışmanın kapsamını aştığından, devre onay verilmemesinin etkisine hâkim görüşü esas alarak kısaca değineceğiz. Bağlamlı nama yazılı payların devrine ilişkin borçlandırıcı işlemin, geciktirici şarta bağlı bir hukukî işlem olduğu öğretide ağırlıkla savunulmaktadır. Hatta ortaklık onayına ilişkin koşulun sözleşmede açıkça öngörülmemiş olsa bile, sözleşmenin bir parçası olduğu ifade edilmektedir. Bu noktada TTK m 494/I ve yeni TTK sisteminin benimsediği birlik teorisi referans alınmaktadır ${ }^{142}$. Dolayısıyla ortaklı̆̆ın devir talebini reddetmesi, taraflar arasındaki ilişkide yer alan koşulun gerçekleşmesinin imkânsız hale gelmesi anlamını taşımaktadır. Borçlar hukuku öğretisinde koşulun gerçekleşmesinin imkânsız hale gelmesi durumunda, geciktirici şarta bağlı hukukî işlemin bağlayıcılığını kaybedeceği ve hiç yapılmamış sayılacağı belirtilmektedir ${ }^{143}$. Başka bir ifadeyle şartın gerçekleşmemesi geriye etkili sonuç doğurmaktadır ${ }^{144}$. Ortaklıklar hukuku öğretisinde de bununla uyumlu sonuçlara ulaşılmaktadır. Ortaklığın bağlamlı payın devrini hukuka uygun olarak reddetmesiyle birlikte, borçlandırıcı işlem de kendiliğinden ortadan kalkmaktadır. Hatta bunun için sözleşmede ortaklık onayına ilişkin bir koşula yer verilmesine dahi gerek yoktur ${ }^{145}$. $\mathrm{Bu}$ durumda devir sözleşmesi ile ortaklı̆̆ın devre onay vermeyi reddettiği zaman arasında kullanılan bir sözleşmesel önalım hakkının da geçmişe etkili olarak ortadan

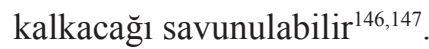

${ }_{142}$ Bağlamlı pay devrinin geciktirici şarta bağlı bir hukuki işlem niteliğinde olduğu yönünde bkz Peter Böckli, Schweizer Aktienrecht (Schultess 2009) 746 para 308; Kläy (n 15) 199; Germann (n 6) 650 para 1511; Max Meyer, 'Vinkulierte Aktien in der Zwangsverwertung' (1997) 93 SJZ 22, 23. Hukukumuzda bu yönde bkz Murat Yusuf Akın, Anonim Ortaklıkta Bağgl Nama Yazılı Hisseler (Vedat Kitapçıllı 2014) 114.

143 Bkz Eren, Genel (n 34) 1170; Theo Guhl and Alfred Koller in Theo Guhl and others, Das Schweizerische Obligationenrecht mit Einschluss des Haldels- und Wertpapierrechts (Schulthess 2000) 60-61 para 28; Isabel Matt, Der bedingte Vertrag im schweizerischen und liechtensteinischen Privatrecht (Schulthess 2014) 323; Claire Huguenin, Obligationenrecht Algemeiner und Besonderer Teil (Schulthess 2012) § 14 para 1316; Andreas Furer, Anton K Schnyder and Katya Roth Pellanda (eds), Obligationenrecht - Allgemeine Bestimmungen, (Art. 1-183 OR), CHK-Handkommentar zum Schweizer Privatrecht (Schulthess 2016) Art 151 para 58.

144 Bkz Matt (n 143) 323.

145 Bu hususta bkz Germann (n 6) 650 para 1511; Kläy (n 15) 199.

146 Bağlamlı nama yazılı payların devrinde ortaklığın onay vermeyi reddetmesine ilişkin farklı sonuca ulaşan bir görüş daha vardır. Buna göre, ortaklığın onay vermeyi reddetmesi, borçlandırıcı işlem bakımından sonraki objektif imkânsızlık durumunu doğuracaktır. Bu yönde bkz Simon Bühler, OTC-Handel mit nichtkotierten Aktien (Schulthess 2016) 264; Hans Caspar von der Crone, Aktienrecht (Stämpfli 2014) 145. Bu durumda, ortaklığın ret kararından önce kullanılan bir önalım hakkının akıbeti, sonraki imkansızlığın türüne ve borçlar hukukunun söz konusu olguya bağladığı hüküm ve sonuçlara göre ayrica tespit edilmelidir.

147 Hukukumuzda ortaklık onayı ile öncesinde gerçekleşen devir sözleşmesinin ilişkilendirilmemesi gerektiği de savunulmaktadır [bu hususta bkz Uzel (n 20) 47 dipnot 47]. Bu görüşe göre, "taraflar, şirketin onay vermesini, bir koşul olarak öngörmedikçe, kaçınma bu işlemin geçerliliğini etkilemez" [bkz Tamer Bozkurt, Anonim Şirketlerde Pay Devrinin Sinırlandırlması (Bă̆lam) -Die Vinkulierung- (On İki Levha 2016) 207-208]. Dolayısıyla tasarruf işlemi onay 


\section{b. Yan ve Satışa Yabancı Edim İçeren Sözleşmelerin Değerlendirilmesi}

Satış ve satışa eş değer işlemlerin tespitinde tüm teorik olasılıkların değerlendirilip her somut olaya önceden bir çözüm önerilmesi olanaksızdır ${ }^{148}$. Örneğin, mal değiş̧imlerinin hakkın kullanılmasına olanak tanımadığı öğretide savunulmaktadır. Fakat somut olayda, önalım hakkı sahibinin yerine getirebileceği bir karş1 edimin söz konusu olması halinde, mal değişiminin de önalım olayının gerçekleşmesini sağlayabileceği belirtilmektedir ${ }^{149}$. Mesela pay karşılığında para değil de misli bir eşyanın mülkiyetinin taahhüt edilmesi böyledir. Üçüncü kişilerle yapılan devir sözleşmelerinde yer alan karşı edimin değerlendirilmesi, özellikle sınırlandırılmamış önalım hakkı bakımından çok önemlidir. Zira bu karşı edim, sınırlandırılmamış önalımda, (hakkın kullanılması halinde) hak sahibiyle payını devreden arasında kurulacak satım sözleşmesindeki edimi de oluşturmaktadır. Alman hukukunda önalım hakkı içeren sözleşmelerde yan edimler BGB § 466 ile özel olarak düzenlenmiştir. Türk-İsviçre sistemindeyse böyle bir kural yoktur ${ }^{150}$. Ancak söz konusu Alman düzenlemesinin çözüm yöntemi İsviçre öğretisinde mevcut sistemle uyumlu bulunmakta ve bunun hem yan edim içeren sözleşmeler hem de sadece satıma yabancı edimlerle kurulan sözleşmeler bakımından genelleştirilebileceği savunulmaktadır. Böylelikle somut olayda, üçüncü kişiyle önalım yükümlüsü arasındaki sözleşmenin, önalım hakkının kullanımını olanaklı hale getiren "satışa eş değer" bir işlem olup olmadığı anlaşılabilir. Buna göre, satım konusu (yani pay) dışında kalan ve bir satış sözleşmesi çerçevesinde değerlendirilmesi mümkün olmayan tüm edim ve karşı edimler dikkate alınır. Söz konusu edimler olmaksızın taraflar arasında (üçüncü kişiyle hakkın yükümlüsü arasındaki) sözleşmenin yapılabileceği kabul ediliyorsa iki yol vardır. Önalım hakkı sahibi tarafından ifa edilmesi mümkün olmayan yükümlülükler ya yok sayılmalıdır ya da kıymeti belirlenebilir olanlara bir değer biçilmelidir ve bu değer satım bedeli gibi dikkate alınmalıdır. Eğer söz konusu edimler olmaksızın taraflar arasında ilgili sözleşmenin yapılamayacağı kabul ediliyorsa, önalım hakkının

verilmemesinden etkilenir, fakat temeldeki borçlandırıcı işlem ayakta kalır. Ortaklığın devre onay vermemesinin hukuki etkisi konusunda bu görüş kabul edilirse, redde kadar geçen sürede kullanılan olası bir önalım hakkının akıbeti konusunda farklı bir sonuca ulaşmak gerekir. Zira önalım olayı bakımından geçerli bir borçlandırıcı işlem yeterli olduğundan ve bu görüşe göre borçlandırıcı işlem üzerinde onayın herhangi bir etkisi olmayacağından kullanılan hakkın hukukî sonuçlarını doğurması gerekir.

148 Hangi hukuksal işlemlerin satışa eș değer kabul edilebileceğine ilişkin "a priori genel bir cevap" verilemeyeceği ve somut olayın şartlarına göre bir değerlendirme yapılması gerektiği öğretide belirtilmiştir [Gümüş (n 44) 435, 440].

149 Bkz Hintz-Bühler (n 4) 98. Hukukumuzda da mal değişiminin kural olarak önalım hakkının kullanımına olanak tanımayacağı belirtilmektedir [örneğin bkz Eren, Mülkiyet (n 32) 442]. Ancak "misli eşya karşılığında yapılan mal değişim sözleşmelerinin” önalım olayını oluşturacağı da belirtilmiştir [bu hususta bkz Kizir (n 28) 1773, 1784 ve aynı yerde dipnot 46]. Gümüş (n 44) 435, 442'de buna karşı çıkmaktadır. Söz konusu görüşe göre, “trampa ile trampa edilen mal para dışında bir misli mal olsa bile önalım olayı gerçekleşmez". Keza sonuncuyla benzer olarak bkz Demirbaş (n 28) 249, 258. Kimi özellikli durumlarda mal değişimlerinin önalım olayı olarak değerlendirilebileceği noktasında bkz Yavuz, Acar and Özen (n 8) 255. Her somut olayın özel olarak değerlendirilmesi gerektiği ve mal değişim sözleşmelerinin önalım olayı oluşturmadığının en baştan savunulmasının mümkün olmadığı yönünde bkz Feyzioğlu, 'Hakkın Kullanılması' (n 117) 222, 247. Yukarıda yer verdiğimiz üzere, yan ve satıma yabancı edim içeren sözleşmeler açısından somut olaya özgü bir değerlendirme yöntemi uygulanmalıdır. Dolayısıyla mal değişim sözleşmelerini de çalışmada bu açıdan değerlendirmiş bulunmaktayı.

150 Önalım hakkının kullanılmasına yol açan satım sözleşmesinde kararlaştırılmış olan yan edimlerle ilgili BK veya MK'da hüküm bulunmadığı öğretimizde ifade edilmektedir [Demirbaş (n 28) 249, 268]. 
kullanımına müsait bir "satışa eş değer" işlem olduğundan bahsedilememelidir ${ }^{151}$. Kanun koyucu ivazlı tüm devir işlemlerini önalım hakkı içeren sözleşmeler bakımından bir koşul olarak değerlendirseydi, bunu anılan şekilde açıç̧a yapabilirdi. Ancak Kanun satışa eş değer işlemlerden bahsetmektedir. Kanunun bu lafzının sınırlayıcı bir etkisi olmalıdır. Somut olayda tarafların sözleşmede belirledikleri edim yerine, bedel ödeme borcunu kabul etmelerinin objektif ${ }^{152}$ olarak mümkün olmayacağı değerlendiriliyorsa artık "satışa eş değer" bir işlemden bahsedilememelidir.

\section{B. Önalım Olayının Gerçekleşmesini Bildirme Yükümlülüğü}

Önalım hakkının yükümlüsü, üçüncü kişiyle satım ya da ekonomik bakımdan satıma eş değer bir sözleşme yaparsa bunu hak sahiplerine bildirmelidir. Bu sözleşmesel bir yükümlülüktür ve ihlali BK m 112 uyarınca tazminat sorumluluğuna neden olur ${ }^{153}$. BK m 241/I'e göre, "Satıcı veya alıcı, satış sözleşmesinin yapıldığını ve içeriğini önalım hakkı sahibine noter aracılığıyla bildirmek zorundadır". Kuralda belirlenen şeklin, paylar üzerinde tesis edilen sözleşmesel önalım hakları bakımından uygulanmasına olanak yoktur. Bu noktada savunulabilecek gerekçeler BK m 237/ III'ün uygulanmamasına ilişkin gerekçelere paraleldir. Bildirim, eğer buna ilişkin bir belirleme yapıldıysa, sözleşmede öngörülen şekilde olmalı ve hak sahibi birden fazlaysa tamamına yapılmalıdır ${ }^{154}$. Yani taraflar arasındaki sözleşmede bildirim bir şekle bağlanmış ve asgari içeriği belirlenmişse, buna uyulması gerekir. Aksi halde usule uygun bir bildirim yapılmamış olmasının sonuçları doğmalı ve önalım hakkının süresi de kural olarak işlemeye başlamamalıdır. Keza BK m 241/I bildirimde bulunma yükümlülüğünü hem alıcı üçüncü kişiye hem de satıcıya yüklemiştir ${ }^{155}$. Taşınmazlar açısından öngörülen bu hükmün, önalım hakkının BK m 238 uyarınca tapuya şerh edilebilmesi ile bağlantısı olmalıdır. Çünkü tapuda şerh olduğu durumda, alıcı taşınmaz üstündeki sözleşmesel önalım hakkından haberdar olabilecektir. Oysa özellikle

151 BGB § 466'yı esas alan genel tespitlere ilişkin olarak İsviçre hukuku açısından özellikle bkz Vischer (n 3) 82, 85-87. Demirbaş (n 28) 249, 268-269'da taşınmazlar üstündeki sözleşmesel önalım hakkı bakımından, yan edimlerin aynen ifa edilememesi durumunda bunların nakitle ifade edilecek değerlerinin esas alınacağını belirtmektedir. Keza yazar nakit dışında yapılan tevdilerin geçersiz olduğunu, öğreti ve uygulamaya atıfla ifade etmektedir.

152 Burada, sözleşmede yer verilen önalım olayının somut olayda gerçekleşip gerçekleşmediğine yönelik bir uyuşmazlık vardır. Taraflar arasında yapılan sözleşmede "satışa eş değer" işlem tanımlanmamışsa sözleşmede tarafların önalım hakkını hangi durumları kapsamak üzere ön gördükleri değerlendirilmelidir. Başka bir ifadeyle, sorun sözleşmenin yorumlanması noktasındadır. Öğretide belirtildiği üzere, “... sözleşmenin içeriğine ilişkin uyuşmazlık noktaları, tarafların birbirine uygun farazi iradelerine göre belirlenir. Buna göre hâkim, makul ve dürüst şekilde davranan tarafların, mevcut şartlar altında, güven teorisine göre tespit edilecek sözleşme iradelerini esas alarak uyuşmazlı̆ğ çözer" [Eren, Genel (n 34) 469]. Bu noktada önalım hakkı tanıyan sözleşmede yer alan önalım olayının anlamının belirlenmesi için sözleşmenin "dürüstlüğe dayalı yorum kuralı" çerçevesinde yorumlanması büyük önem taşıyacaktır (sözleşmenin yorumlanmasında dürüstlüğe dayalı yorum kuralı ve bunu oluşturan ilkeler açısından bkz ibid 472).

153 Bu bağlamda bkz Hintz-Bühler (n 4) 105; Germann (n 6) 697 para 1623; Fischer (n 6) 64. OR m 216d bağlamında bu yönde bkz Fasel (n 36) Art 216d para 5. Hukukumuzda taşınmazlar üzerindeki önalım hakkına ilişkin olarak satıcı bakımından bu yönde bkz Gümüş (n 44) 435, 445; Demirbaş (n 28) 249, 266.

154 Bkz Forstmoser and Küchler (n 7) 389 para 1240.

155 Hukukumuzda İsviçre hukukundan farklı olarak bilgilendirme yükümlülüğünün BK m 241'de hem alıcıya hem satıcıya yüklendiği, oysa İsviçre hukukunda bunun sadece satıcıya yüklenmiş olduğu noktasında açıklamalar için bkz Kizir (n 28) 1773, 1786; Gümüş (n 44) 435, 443. Benzer olarak bkz Aydoğdu and Kahveci (n 8) 290. 
anonim ortaklıklarda, alıcı, payı devreden onu bilgilendirmedikçe, pay üzerinde sözleşmesel önalım hakkı olduğunu bilemez ${ }^{156}$. Çünkü bu hak taraflar arasında bir sözleşmede kalmakta, ne esas sözleşmede ne de pay için senet basıldıysa burada bilgi olarak yer almaktadır. Ayrıca alıcı, hakkın öngörüldüğü pay sahipleri sözleşmesine de kural olarak yabancı birisidir. Bu nedenle BK m 241/I hükmü anonim ortaklık payları üzerindeki sözleşmesel önalım hakları bakımından kıyasen uygulanmalıdır. Önalım olayının gerçekleştiğini bildirme yükümlülüğü satıcı bakımından kabul edilmeli, fakat alıcı üçüncü kişinin böyle bir yükümlülük altında olmadığı belirtilmelidir.

Hak sahibinin hakkını kullanabilmesi, önalım olayının gerçekleştiğini öğrenmesine bağlıdır. Bildirim, üçüncü kişiyle bir sözleşme yapıldığı bilgisini ve bu sözleşmenin içeriğine ilişkin hususları kapsamalıdır ${ }^{157}$. İçerikten kast edilenin özellikle satım sözleşmesinin esaslı unsurları olduğu belirtilmektedir ${ }^{158}$. Bildirim, satıma sunulan payların sayısını, alıcının şahsını ve satım bedelini kapsamalıdır ${ }^{159}$. Ayrıca ödeme veya ifaya ilişkin diğer koşulların da bildirimin konusu olması gerektiğine öğretide işaret edilmektedir ${ }^{160}$. Önalım olayının gerçekleşmesine neden olan hukuki işlem, tamamlanmış olmalıdır. Başka bir ifadeyle anılan işlem hukuken geçerli bir şekilde yapılmış olmadıkça hakkın kullanımı bakımından önalım olayının gerçekleştiği de kabul edilemez ${ }^{161}$. Örneğin, pay devri bir satım sözleşmesine dayanıyorsa, bu sözleşmenin bağıtlanmış olması gerekir. Yoksa soyut anlamda sözleşme ön görüşmeleri yapılmış olması, bildirim yükümlülüğü açısından önemli değildir ${ }^{162}$.

\section{C. Önalım Olayının Gerçekleşmesinin Engellenmesi}

Üçüncü kişiyle girişilen hukuki işlemin önalım hakkının kullanımını engelleyecek şekilde olması, dürüstlük kuralına aykırılık iddialarını gündeme getirecektir. Dürüstlük kuralına aykırılık her durumda kolaylıkla kabul edilmemelidir ${ }^{163}$. Bu nedenle satıma yabancı edimler içeren her sözleşme hemen dürüstlük kuralına aykırılık olarak değerlendirilemez. Ancak bazen önalım hakkının yükümlüsüyle üçüncü kişi arasındaki sözleşmede, hakkın kullanımını engellemek ya da güçleştirmek için hükümler öngörülebilir. Örneğin taraflar arasındaki sözleşmede devir için olması gereken fiyatın çok üstünde bir bedel belirlenmiş ya da yapılan işlem satımdan farklı gösterilmiş olabilir.

\footnotetext{
156 Oysa limited ortaklıklar bakımından sistemimiz farklıdır. Önalım hakkına ilişkin limited ortaklık sözleşmesine hüküm konulabilmektedir (TTK m 577/I a). Keza bu hak, ortaklık sözleşmesiyle birlikte tescil ve ilan edilmektedir. Ayrıca esas sermaye payı için TTK m 593/II uyarınca "ispat aracı şeklinde veya nama yazılı" olarak senet düzenlendiyse bu senette ortaklık sözleşmesinde önalım hakkı öngörüldüğünün açıkça belirtilmesi gerekmektedir. Limited ortaklık ortağı, ortaklık sözleşmesinde öngörülmesi halinde önalım hakkından haberdar olabilecek hukukî imkândan yoksun değildir.

157 Bu hususta bkz Hintz-Bühler (n 4) 105.

158 Bu yönde bkz Gümüş (n 44) 435, 444; Demirbaş (n 28) 249, 265.

159 Bu bağlamda borçlar hukukumuz açısından bkz Aydoğdu and Kahveci (n 8) 290.

160 Bu yönde bkz Forstmoser and Küchler (n 7) 389 para 1241.

161 Bu hususta ayrica bkz Fischer (n 6) 64.

162 Bu bağlamda olmak üzere bkz Hintz-Bühler (n 4) 99.

163 Bu hususta özellikle bkz Vischer (n 3) 82, 87.
} 
Üçüncü kişiyle yapılan işlemin önalım hakkının kullanımını engelleme amacı taşıması halinde uygulanabilecek hukuki kurum ve kurallar mevcuttur. Öğretiye göre, üçüncü kişiyle yapılan sözleşmede yer alan bu hükümler olmasaydı da, sözleşmenin yapılacağı dürüstlük kuralı uyarınca kabul edilebiliyorsa, ilgili hükümler yok sayılmalıdır. Yine dürüstlük kuralı uyarınca sözleşmenin farklı şekilde yapılması gerektiği kanaatine ulaşı1ırsa, sözleşmenin buna göre uyarlanması da önerilmektedir. Bedelin fazla yüksek belirlendiği bir sözleşme bakımından gerçek değerin tespit edilmesi bu duruma örnek olarak verilmektedir. Söz konusu uygulamaların dogmatik olarak muvazaayı düzenleyen BK m 19'a ve/veya ahlaka aykırılıkla ilgili olarak BK m 27'ye ve/veya BK m 241/III'ün amaca uygun yorumlanmasına dayanacağ belirtilmektedir. Anılan düzenlemelerle bağlantılı olarak BK m 175'in de uygulama alanı bulabileceği göz ardı edilmemelidir ${ }^{164}$. BK m 175/I'e göre, "taraflardan biri, koşulun gerçekleşmesine dürüstlük kurallarına aykırı olarak engel olursa, koşul gerçekleşmiş sayılır”. Bu durumda önalım hakkı yükümlüsünün üçüncü kişiyle yaptığı işlem önalım olayının gerçekleşmesini sağlar. Hatta üçüncü kişiyle önalım hakkının kullanımını engellemek amacıyla yapılan işlem bir şekilde geçersiz olsa dahi, bunun öne sürülmesi MK m 2/II'ye göre hakkın kötüye kullanımı teşkil edecek ve BK m 175 ile bağlantılı olarak da hakkın kullanılabilmesi gündeme gelecektir. BK m 175'in uygulanması, önalım sözleşmesinin niteliği bakımından koşul teorisinin kabul edildiği durumlarda zaten olağan bir durumdur. Ancak kuruluş teorisinin kabul edildiği durumlarda da kıyasen bu hükmün uygulanacağı kabul edilebilir. Zira BK m 175 burada hem menfaatler dengesine uygundur hem de somut olayda MK m 2'de öngörülen esasların gerçekleştirilmesinin bir aracı olmaktadır.

\section{Hakkın Kullanılması ve Bunun Sonuçları}

\section{A. Hakkın Kullanılması}

\section{Konunun Bölünememesi İlkesinin Hakkın Kullanılması Üzerinde Etkisi}

Adi ortaklık niteliğindeki pay sahipleri sözleşmelerinde, taraflara önalım hakkı tanınıyorsa, sözleşmeye hakkın kullanımına yönelik hükümler konulmasında büyük fayda vardır. $\mathrm{Bu}$ ihtiyaç adi ortaklığın yapısal özelliklerinden kaynaklanmaktadır. $\mathrm{Bu}$ tip sözleşmelerde, açık bir hüküm olmadıkça, ilgili hakkın tüm ortaklara (pay sahipleri sözleşmesinin tüm taraflarına) ait olacağı öğretide belirtilmektedir. Ancak arzulanan durum aslen böyle olmadığ için pay sahipleri sözleşmesine somut bir hüküm konulması gerektiği vurgulanmaktadır ${ }^{165}$.

\footnotetext{
164 Önalım hakkının kullanımının dürüstlük kuralına aykırı şekilde engellenmesi olasılığıyla ilgili yer verdiğimiz açıklamalarla ilgili olarak ibid 82, 87.

165 Açıklamaya ilişkin olarak bkz Hintz-Bühler (n 4) 96.
} 
İsviçre'de özellikle alım hakkıyla ilişkili olarak en sık rastlanan düzenlemenin, ortaklardan her birisinin mevcut payı oranında hak kapsamındaki payların iktisabını talep edebilmeye yönelik olduğu belirtilmektedir ${ }^{166}$. Bu noktada iki olasılıkla karşılaşı1ır. Birincisi, ilk aşamada payların birlikte iktisap edilip daha sonra pay sahiplerine devredilmesi halidir. İkincisi de münferit olarak tarafların, kendilerine düşen pay sayısına göre doğrudan doğruya haklarını kullanmalarıdır. Anılan ikinci olasılıkta hak sahiplerinin bir kısmının hakkı kullanmamaları durumuyla karşılaşmak mümkündür. Hakkın yükümlüsü için bu ciddi bir olumsuzluk teşkil eder. Çünkü ilgili kişinin elinde kalan payların devredilebilirliği güçleşiri ${ }^{167}$. Bu sebepten dolayı söz konusu kazandırıcı hakkın, pay sahibinin paylarının tamamını kapsadığı kabul edilir ${ }^{168}$. Hakkın bölünmeksizin kullanılmasına yönelik ilkeyi meşrulaştıran bu hususun bir başka sonucu daha vardır. Hakkı kullanacak kişilerin hakları, hakkını kullanmayan kişilerin payları oranında genişler ${ }^{169}$. Eğer hak sahipleri tarafından ilgili payların tamamı alınmak istenmiyorsa, hakkın da bir bütün olarak kullanılmadığı kabul edilmelidir ${ }^{170}$. Alım hakkının kullanılmasına ilişkin öğretinin söz konusu tespitlerinin önalım hakkı bakımından da geçerli olduğu kabul edilmelidir.

Öğretimizde, hakkı kullanacak kişilerin haklarının, hakkını kullanmayan kişilerin payları oranında genişleyeceği görüşü kısmen eleştirilmiştir. Buna göre, önalım hakkının düzenlendiği sözleşmede belirlenen fiyat üçüncü kişinin verdiği fiyattan düşük ise, satıcı kullanılmayan önalım hakkına denk düşen payların üçüncü kişiye değil de diğer önalım hakkı sahiplerine satılması halinde mağdur durumuna düşecektir. $\mathrm{Bu}$ nedenle somut olaydaki menfaatler dengesine uygun bir çözüm aranmalıdır ${ }^{171}$. $\mathrm{Bu}$ noktada belirtmek isteriz ki, önalım hakkı kural olarak satışa sunulan payların tamamı üstünde ya kullanılmaktadır ya da kullanılmamış kabul edilmektedir. Taraflar aralarındaki sözleşmede kısmi kullanımı kabul ettiyse zaten buna uyulacaktır. Sözleşmede herhangi bir düzenleme yoksa hakkı kullanmak istemeyenlere ilişkin kısmın diğer paydaşlara dağıtılmasına yönelik uygulama zaten satıcıyı koruma amaçlıdır. Önalım hakkını oluşturan sözleşmenin hukuki niteliği konusunda hangi görüş kabul edilirse edilsin, bu yönde bir sonuca ulaşmak mümkündür. Örneğin koşul teorisi kabul edilirse, satıcı geciktirici koşula bağlı bir satım sözleşmesini en baştan diğer pay sahipleri ile yapmıştır. Önalım iradesinin açıklanmış olması koşulu

\footnotetext{
$\overline{166}$ Bu hususlarda ibid 96.

167 Örneğin önalım hakkı yükümlüsünün azınlık teşkil eden tüm paylarını üçüncü bir kişiye devretmek istemesi durumunda söz konusu hakkı pay sahipleri sözleșmesi taraflarından bazılarının kullanıp bazılarının kullanmaması durumunda, hakkın yükümlüsünün paylarının değerinin düşmesi olasılı̆̆ı yüksektir. Zira bir bütün olarak azınlık konumunun olanaklarını sunan paylar artık bölünmüştür ve bu olanağı sunması artık mümkün değildir.

168 Devrin payların tamamını kapsamasından, üçüncü kişiyle yapılan devir işlemine konu payların tamamıdır. Pay sahibinin tüm payları bu işlemin konusunu oluşturuyorsa doğal olarak önalım (veya alım) hakkı o pay sahibinin tüm paylarını kapsamış olacaktır.

169 Öğretimizde, Yargıtay'ın HGK 6-739/52 17.2.1993 kararına atıfla, üç hissedarlı bir taşınmaz üzerindeki önalım hakk bakımından bu sonuca ulaştığı belirtilmiştir (bu hususta bkz Okutan Nilsson (n 6) 221 ve özellikle aynı yerde dipnot 348).

170 Bu hususlarda özellikle bkz Hintz-Bühler (n 4) 96.

171 Eleştiri için bkz Okutan Nilsson (n 6) 223.
} 
gerçekleştirmekte ve kurulmuş olan satım sözleşmesini etkin kılmaktadır. Diğer pay sahipleri, önalım hakkı içeren sözleşmede belirlenen fiyata uygun olarak satışa sunulan tüm payları satın almıyorlarsa zaten önalım hakkının kullanılmadığı kabul edilmektedir ve bu şekilde satıcı korunmaktadır. Kuruluş teorisi kabul edilirse de ulaşılacak sonuç değişmez. Önalım yükümlüsüyle önalım hakkı sahibi arasında, hak sahibinin tek taraflı bir irade açıklamasıyla önalım konusunun satımına ilişkin bir sözleşme kurulur. Önalım sözleşmesinin konusu üçüncü kişiye satılan paylar olduğundan hakkın kullanımı ilgili payların tamamı üzerinde bir satım sözleşmesi kurulmasını gerektirir. Sonuçta birinci olasılıkta taraflar arasındaki çifte koşula bağlı satım sözleşmesi, ikinci olasılıktaysa önalım hakkını düzenleyen sui generis sözleşme vardır. Bu sözleşmeleri dikkate almadan, aradaki ilişkiye taraflardan sadece birisinin menfaati gözetilerek müdahale edilmesi sistemimize uygun görünmemektedir. Dolayısıyla ilgili görüşe katılamamaktayız.

Birden fazla kişinin "birlikte" önalım hakkına sahip olduğu durumlarda, hakkın birlikte, özellikle bir temsilci vasıtasıyla kullanılması gerekmektedir. Hakkın kullanımını takiben, hak sahipleri paylarını devretmek isteyen pay sahibine karşı kararlaştııılan kapsamdaki payları birlikte devralma yükümlülüğü altına girer. Böyle bir durumda, önalım hakkının yükümlüsü devralınan payların, taraflar arasında nasıl pay edileceği meselesiyle uğraşmak zorunda kalmaz ${ }^{172}$.

Sözleşmede hak sahipleri tarafından, hakkın yükümlüye karşı doğrudan doğruya ve münferit olarak kullanılacağı kararlaştırılmışsa, hakkın kullanımına ilişkin hususların detaylı bir şekilde kurala bağlanması tarafların menfaatine olur. Özellikle hak sahiplerinin devre konu tüm payları satın alma yükümlülüğünde olmadığı kararlaştırılmışsa önalım sürecinin nasıl işleyeceği sözleşmede düzenlenmelidir. Keza payların nasıl paylaşılacağıyla birlikte hak sahiplerinin devre konu tüm payları almaya hazır olup olmadıklarına ya da önalım yükümlüsünün payları üçüncü kişiye devredip devredemeyeceğine karar veriliyorsa bu sürecin sözleşmeyle düzenlenmesi olası uyuşmazlıkların çözümü bakımından büyük önem taşırı173.

\section{Hakkı Kullanma Süresi}

\section{a. Sürenin Başlangıcı}

Aksine bir sözleşme olmadıkça, usulüne uygun bir bildirimle birlikte, hak sahibi veya sahiplerinin önalım hakkını kullanmalarına ilişkin süre başlar ${ }^{174}$. Sürenin bildirim ile başlamasının nedeni, hak sahiplerinin, haklarını ilgilendiren bir sözleşmenin kurulduğunu ve sözleşmenin koşullarını ancak bu şekilde öğrenebilecek

\footnotetext{
172 Anılan noktada özellikle bkz Forstmoser and Küchler (n 7) 381 para 1205.

173 ibid 383-384 para 1216'da söz konusu soruna işaret edilmektedir.

174 ibid 389 para 1241.
} 
olmalarıdır. Yukarıda belirtildiği üzere bildirim, sözleşmenin kurulmasını ve içeriğini kapsar. BK m 242'nin lafzı, sürenin işlemeye başlaması için sadece sözleşmenin yapılmış olmasının bildirimini yeterli kabul etmektedir. Ancak öğretide haklı olarak belirtildiği üzere, BK m 242, BK m 241/I ile birlikte değerlendirilmelidir. Dolayısıyla sürenin işlemeye başlaması için hem sözleşme yapıldığı hem de bu sözleşmenin içeriği hususunda hak sahibinin bilgilendirilmesi gerekir ${ }^{175}$. Bilgilendirme Kanunda veya taraflarca yapılan sözleşmede belirtilen asgari içeriği kapsamıyorsa, hak sahibi bakımından üç aylık sürenin işlemeye başlamaması gerekir.

Hak sahipleri, sözleşme ve içeriğini bildirimden önce öğrenmişse, süre başlangıcı için fiilen öğrenme tarihi esas alınabilir. Hukukumuzda taşınmazlarda kanunî önalım hakkının kullanımına ilişkin bir karara ${ }^{176}$ istinaden fiili öğrenme söz konusu olsa bile sürenin ancak bildirimle başlayacağı sözleşmesel önalım hakkı bakımından ifade edilmiştir ${ }^{177}$. Hem BK m 241/I hem MK m 733/III önalım olayının gerçekleştiği bildirimini şekle bağlamış ve sürenin işlemesi de devam eden hükümlerle bildirime bağlanmıştır. Şekle bağlı bildirim ve sürenin işlemeye başlaması arasındaki sıkı lâfzî ilişki, uygulama ve öğretide sürenin işlemesinin ancak bildirimle başlayabileceğine yönelik görüşü desteklemektedir. Buna rağmen öğretide bildirimden önce öğrenme varsa, sürenin bu andan itibaren işleyeceğini kabul eden görüşün de var olduğunu belirtmemiz gerekir ${ }^{178}$. Bu hususta bir sonuca ulaşabilmek için, incelediğimiz konuda BK m 241'in kıyasen uygulandığ ve bu nedenle bildirimde bulunma yükümlülüğünün kural olarak bir şekle bağlı olmadığı gözetilmelidir. Dolayısıyla, BK m 241'in bildirim şekli ile sürenin başlaması için bildirimi esas alan kuralları arasındaki sıkı lâfzî bağ zayıflamaktadır. Bu nedenle önalım olayının bildirilmesi gereken içeriğini bir şekilde öğrenen hak sahibi bakımından üç aylık sürenin öğrenme itibarıyla işlemeye başlayacağını kabul etmek yerinde olur. Ancak bu hususun hakkın yükümlüsü bakımından ispatının önemli zorluklar ${ }^{179}$ taşıyacağı da göz önünde bulundurulmalıdır.

\section{b. Sürenin Hukuki Niteliği ve Uzunluğu}

Önalım hakk1, yenilik doğurucu nitelikte olduğundan, hak düşürücü bir süreye tabi olması gerekir ${ }^{180}$. Doğrudan kanunî bir düzenleme olmamasına karşın, BK m 242'nin kıyasen uygulanması ve hakkın bildirim tarihinden itibaren üç ay içinde kullanılması kabul edilebilir. İsviçre hukukunda da OR m 216e'nin kıyasen uygulanması paylar

\footnotetext{
175 Bu hususta özellikle bkz Gümüş (n 44) 435, 444.

176 Bkz Yargıtay HGK, 6-230/244, 13.4.2005 (karar için bkz Kazancl - İçtihat Bilgi Bankası <http://www.kazanci.com> Erişim Tarihi 10 Temmuz 2018)

177 Bu yönde bkz Eren, Mülkiyet (n 32) 446; Eren, Özel (n 32) 214; Kizir (n 28) 1773, 1786; Demirbaş (n 28) 249, 265.

178 Bu görüşte Zevkliler and Gökyayla (n 28) 71.

179 BK m 241'de öngörülen noter aracılığıyla bildirim esasının, sürenin başlangıcının tespiti açısından ispat kolaylığı sağlayacağı hususunda bkz Kizir (n 28) 1773, 1787.

180 Bkz Buz (n 29) 262. Anonim ortaklıklar hukukumuz bakımından önalım hakkının zamanaşımına bağlı olmayan bir hak olduğu noktasında bkz Okutan Nilsson (n 6) 220.
} 
üzerindeki sözleşmesel önalım hakları bakımından önerilmektedirr ${ }^{181}$. BK m 242'nin söz konusu hükmü tamamen taşınmazlar özelinde düşünülmemelidir. Zira İsviçre hukukunda, yargının OR m 216e'den önce eski ZGB m 681/III bağlamında böyle bir tutum alması, öğreti tarafından ciddi anlamda eleştirilmiştir. Anılan dönemde Federal Mahkeme, eski ZGB m 681/III'ün sadece orada düzenlenmiş olan önalım hakları için uygulanacağını içtihat etmiş, diğerleri içinse hakkın kullanımı bakımından "uygun bir süre" aranması gerektiği kanaatine ulaşmıştır ${ }^{182}$. Mahkemenin ulaştı̆̆ bu sonuç, pratik olmayan ve hukuk güvenliğine hizmet etmeyen bir görüş olarak nitelenmektedir ${ }^{183}$. Taraf menfaatleri önalım hakkı içeren sözleşmeler bakımından neredeyse aynı olduğundan, kıyasen BK m 242'deki sürenin uygulanabileceğine ilişkin görüşe katılmaktayız. Dolayısıyla, hakkın üç aylık bir hak düşürücü süreye bağlı olduğu, paylar üzerindeki önalım hakkının kullanılması bakımından ifade edilmelidir. Sürenin hak düşürücü nitelikte kabul edilmesinin doğal bir sonucu da, bunların zamanaşımı süreleri gibi durması ya da kesilmelerinin mümkün olmaması ve hâkimin söz konusu süreyi kendiliğinden dikkate almasının gerekmesidir ${ }^{184}$.

BK m 242'nin kıyasen uygulanmas1, tarafların sözleşmesel bir düzen benimsememeleri halinde söz konusu olmalıdır ${ }^{185}$. Taraflar sözleşmeyle farklı bir süre öngörebilirler. Hatta öğretide, olası belirsizliklerin aşılması için, pay sahipleri sözleşmelerinde, kanunî süreyle aynı olsa dahi, süreye ilişkin düzenleme yapılmasının yararlı olacağı vurgulanmaktadır ${ }^{186}$. Tarafların BK m 242'de düzenlenen üç aylık hak düşürücü süreden hangi ölçüde farklı bir süre belirleyebilecekleri ise ayrı bir sorundur. İsviçre öğretisinde, özellikle OR m 216e'deki üç aylık süre bağlamında mesele tartışmalıdır. Bir görüşe göre, bu süre sözleşmeyle hem uzatılabilmekte hem de kısaltılabilmektedir ${ }^{187}$. Başka bir görüşe göreyse, bu sürenin kısaltılması mümkündür, ancak uzatılması mümkün olmamalıdır ${ }^{188}$. Kanımızca, BK m 242 açısından ikinci görüşe uygun bir sonuca ulaşmak gerekir. BK m 242'de (taşınmazlar bakımından da olsa) iki yıllık bir üst sınır olması, kanun koyucunun iradesinin bu bağlamda süre uzatımlarını desteklemediği yolunda değerlendirilmelidir. Ayrıca, hakkın kullanımına ilişkin sürenin, hak düşürücü süre olarak kabul edilmesinin, bunun sözleşmesel olarak uzatılabilmesi olanağını en baştan devre dışı bıraktığı

\footnotetext{
181 Bu bağlamda bkz Forstmoser and Küchler (n 7) 390 para 1243; Germann (n 6) 698 para 1625; Hintz-Bühler (n 4) 100; Vischer (n 3) 82, 83; Fischer (n 6) 65-66.

182 BGE 83 II 12, 16 (karar için bkz <https://www.bger.ch/ext/eurospider/live/de/php/clir/http/index.php?highlight_docid=atf $\%$ 3A\%2F\%2F83-II-12\%3Ade\&lang=de\&zoom=\&type=show_document $>$ Erişim Tarihi 13 Mart 2018).

183 Eleştiri bağlamında bkz Hintz-Bühler (n 4) 100. İsviçre öğretisinde, OR m 216e'de yer verilen sürenin hukuk güvenliği nedeniyle uygulanması gerektiği ifade edilmektedir [bkz Fischer (n 6) 65].

184 Bu hususta bkz Eren, Mülkiyet (n 32) 445-446; Eren, Özel (n 32) 214. Benzer olarak bkz Demirbaş (n 28) 249, 266; Buz (n 29) 264

185 Bu bağlamda bkz Forstmoser and Küchler (n 7) 390 para 1243; Germann (n 6) 698 para 1625; Vischer (n 3) 82, 83.

186 Bu bağlamda bkz Hintz-Bühler (n 4) 100-101.

187 Bkz Fasel (n 36) Art 216e para 2; Binder (n 133) Art 216e para 3.

188 Bu hususta OR m 216e özelinde bkz Atteslander-Dürrenmatt (n 28) Art 216e para 3. Anonim ortaklık payları üzerinde tanınan sözleşmesel önalım hakkı bağlamında bkz Hintz-Bühler (n 4) 100.
} 
öğretide savunulmaktadır ${ }^{189}$. Dolayısıyla tarafların paylar üzerinde önalım hakkı tesis ederken bu hakkın kullanımı bakımından belirlenecek olan hak düşürücü süreyi, MK m 2'ye aykırı olmamak üzere, üç aydan kısa olarak belirleyebilmeleri, fakat bundan uzun bir süre öngöremeyecekleri kabul edilmelidir.

\section{c. BK m 242'de Öngörülen İki Yıllık Sürenin Uygulanamaması}

BK m 242'de yer almakla birlikte, OR m 216e'de yer almayan hakkın "her hâlde satışın yapılmasından başlayarak iki yıl içinde" kullanılması zorunluluğunun ise paylar üzerinde tesis edilen sözleşmesel önalım hakkı bakımından uygun olmadığı savunulabilir. Buradaki süre MK m 733/IV ile uyum içindedir. MK m 733/IV, paylı mülkiyette olan taşınmazlarda paydaşlardan birisinin payını devretmesi durumunda, diğer paydaşların kanunî önalım hakkını düzenlemektedir. MK m 735/III'e göre, kanunî önalım hakkının kullanılmasına ilişkin hükümler sözleşmeden doğan önalım hakkında da uygulanır. BK m 242'deki iki yıllık sürenin MK m 733/IV'te öngörülen iki yıllık süre ile uyum sağlama amacıyla getirildiği düşünülebilir ${ }^{190}$. Zira İsviçre ZGB m 681a/II'de yeni malikin sicile tescilinden itibaren iki y1lın geçmesiyle hakkın kullanılamayacağı düzenlenmesine rağmen BK m 242'nin karşılığı olan OR m 216e'de böyle bir düzenlemeye gidilmemiştir. Bu nedenle İsviçre öğretisinde hâkim görüş, taşınmazları ilgilendiren sözleşmesel önalım haklarının OR m 127'de düzenlenen genel zamanaşımı süresine tabi olduğudur ${ }^{191}$.

BK m 242'de yer alan, hakkın "her hâlde satışın yapılmasından başlayarak iki yıl içinde" kullanılması zorunluluğunun pay üzerindeki sözleşmesel önalım hakkı bakımından uygulanamayacağını düşünmekteyiz. Bunun nedeni, burada yapılan uygulamanın bir "kıyasen" uygulama olmasıdır. Kanun koyucunun BK m 242'de öngördüğü iki yıllık süre, taşınmazlar bakımından uygun olabilir, ancak ortaklık payı üzerinde kurulan önalım hakkı bakımından uygun değildir. Taşınmazların tersine, özellikle kanunî tipe uygun bir anonim ortaklıkta pay devri, ortaklık onayına veya pay defterine yapılacak bir kayda gerek kalmadan gerçekleşmektedir. Bu anlamda pay defterine yapılacak kayıt açıklayıcıdır ${ }^{192}$. Pay defterine yapılacak kayıt, tapu siciline yapılan tescille karşılaştırılamaz. Ayrıca somut olayda pay defterine bir kayıt yapılsa dahi, anonim ortaklık pay defterindeki üçüncü kişilere ait kayıtların

\footnotetext{
189 Bu yönde bir açıklama için bkz Atteslander-Dürrenmatt (n 28) Art 216e para 3.

190 Kanun koyucunun iki yıllık süreyi öngörürken, önalım olayının bildirilmemesine bir yaptırım uygulamamış olması öğretimizde eleştirilmiştir. Bu süre içinde kullanılmamış olması, hakkın kaybına neden olacaktır [bu hususta Kizir (n 28) 1773, 1790; Aydoğdu and Kahveci (n 8) 290]. Öğretideki bu değerlendirme bildirim yükümlülüğünün yerine getirilmemiş olmasının özel bir yaptırımı olmadığı şeklinde anlaşılabilir. Yoksa bildirim yükümlülüğünün yerine getirilmemiş olmasının özellikle satıcı bakımından sözleşme ihlali teşkil edeceği ve bu nedenle yaptırımsız bir yükümlülük olmadığı belirtilmelidir.

191 Bkz Atteslander-Dürrenmatt (n 28) Art 216e para 1; Binder (n 133) Art 216e para 3.

192 Eski TTK döneminde pay defterine kaydın hukukî niteliği konusunda detaylı açıklamalar için bkz Narbay, Pay Defteri (n 9) 129-158. Yazar, detaylı bir inceleme neticesinde Eski TTK dönemi açısından pay defterine kaydın kurucu bir etkiye sahip olmadığını, açıklayıcı bir etkide olduğunu belirtmiştir (buna ilişkin olarak ibid 146 ve 158). Yürürlükteki hukukumuz bakımından da aynı sonuca ulaşılmaktadır [bu yönde Uzel (n 20) 85].
} 
incelenebilmesi hususu tartı̧̧malı bir konudur. Oysa tapu sicili alenidir. Dolayısıyla olası bir devir işleminden hak sahiplerinin haberdar olması, anonim ortaklık payları bakımından kolay değildir. Bu durumun zorluğu özellikle hamiline yazılı paylarda daha da belirgindir. Hamiline yazılı pay senetlerine sahip pay sahibinin pay defterine kaydı dahi söz konusu olmayacaktır. Bu koşullar altında sözleşmenin yapılmasından itibaren iki senelik bir sürenin geçirilmesi, konusu anonim ortaklık payı olan önalım hakkı bakımından kısadır ve bu sürenin uygulanması olası kötüye kullanmaları, hakkın yükümlüsü bakımından, çok kolay hale getirecektir.

\section{Hakkı Kullanma Usulü}

Önalım hakkı taraflar arasında kararlaştırılan usule uygun olarak kullanılmalıdır. Yenilik doğurucu bir hak olduğu için bunların kullanımına yönelik esaslar önalım hakkına da uygulanır. Yenilik doğurucu haklar kullanıldıktan sonra, geri alınamaz, bunlardan dönülemez ${ }^{193}$. Ayrıca şarta da yabancı haklardır ${ }^{194}$. Bu nedenle öğretide hakkın kullanımına yönelik açıklamanın koşulsuz ve geri alınamaz şekilde yapılması gerektiği vurgulanmaktadır ${ }^{195}$. Aksi halde söz konusu kullanım, duruma göre yeni bir sözleşme veya mevcut sözleşmenin değiştirilmesi için icap olarak dahi değerlendirilebilir ${ }^{196}$.

BK m 242'ye göre, taşınmazlarda sözleşmesel önalım hakkı, kural olarak, dava yoluyla kullanılmaktadır ${ }^{197}$. Hükümde öngörülen bu usulün anonim ortaklık payları üzerindeki sözleşmesel önalım hakkının kullanımına uygulanması mümkün değildir. Taşınmazlara ilişkin bu düzenlemenin istisnai karakterde olduğu ve uygulama alanının genişletilmemesi gerektiği kabul edilmelidir. Zira yenilik doğurucu hakların kullanımında temel ilke hak sahibinin ulaşması gerekli tek taraflı bir irade beyanı ile hakkını kullanmasıdır ${ }^{198}$. Dolayısıyla pay üzerindeki önalım hakkının kullanımı bakımından, hak sahibi ya da sahiplerinin hakkın yükümlüsü ya da yükümlülerine yönelteceği ulaşması gerekli bir irade beyanı gerekli ve yeterlidir ${ }^{199}$.

BK m 242'de sözleşmeden doğan önalım hakkının tapu siciline tescilli olup olmamasına göre kime karşı kullanılacağı hususu değişmektedir. Taşınmazlar

193 Bkz Buz (n 29) 256-258.

194 Bu bağlamda ibid 258. Genel olarak yenilik doğurucu hakların söz konusu özellikleri hakkında bkz Eren, Genel (n 34) 6869.

195 Anılan çerçevede bkz Forstmoser and Küchler (n 7) 390 para 1244; Germann (n 6) 698 para 1624; Fischer (n 6 ) 63.

196 Bu bağlamda bir olasılık için bkz Forstmoser and Küchler (n 7) 390 para 1245. Örneğin, öğretimizde bozucu yenilik doğuran bir hak olarak nitelenen fesih ile ilgili olarak şu şekilde bir tespite yer verilmektedir: "Hak sahibinin fesih beyanından dönmesini kabul eden karşı tarafın, bu davranışı, olsa olsa yeni bir sözleşme ilișkisinin kurulması olarak yorumlanabilir" [Eren, Genel (n 34) 68]. Hakkın kullanılmasıyla taraflar arasında kurulan sözleşme ilişkisinin ancak ikale anlaşması ile sona erdirilebileceği hususunda bkz Demirbaş (n 28) 249, 272.

197 Tarafların gerek MK gerekse BK'da öngörülen önalım haklarını dava yolu dışında, yenilik doğurucu bir işlemle kullanabileceklerine dair bir sözleșme yapabilecekleri, ancak bunun adi yazılı șekilde olması gerektiği yönünde bkz Kizir (n 28) 1773, 1789; Gümüş (n 44) 435, 450.

198 Bkz Buz (n 29) 252; Eren, Genel (n 34) 66. Keza aynı yönde önalım hakkıyla ilgili olarak bkz Demirbaş (n 28) 249, 253; Aydoğdu and Kahveci (n 8) 294.

199 Bu bağlamda ayrıca bkz Fischer (n 6) 64-65. 
bakımından hak daha önce tapu siciline şerh edilmiş ve taşınmaz daha sonra alıcı adına tescil edilmişse önalıma ilişkin dava alıcıya, yoksa satıcıya karşı açılmaktadır ${ }^{200}$. Anılan düzenlemeden farklı olarak, anonim ortaklık payları üzerinde tesis edilen sözleşmesel önalım hakkının sadece satım sözleşmesinin satıcısına karşı kullanılabileceği belirtilmelidir. Değerlendirdiğimiz önalım hakk1, pay sahipleri sözleşmesinde tarafların birbirlerine tanıdıkları bir haktır ve taşınmazlarda olduğu gibi aynî-benzeri bir etkiye sahip değildir. Bu noktada BK m 242'de tapu siciline göre yapılan ayrım anonim ortaklık pay defterine alıcının kayıt edilmiş olup olmamasına göre yapılamaz. Hukukumuzda sözleşmelerin taraflar arasında etki gösterdiği ve BK m 242'nin taşınmazlar özelinde bir hüküm olduğu değerlendirilerek, hakkın sadece satıcıya yani önalım sözleşmesinin yükümlüsüne karşı kullanılabileceği ifade edilmelidir.

\section{B. Hakkı Kullanmanın Sonuçları}

\section{Hakkın Kullanımının Taraflar Arasında Etki Doğurması}

Önalım hakkının kullanılmasının etkisi, bu hakkı öngören sözleşmenin hukukî niteliğiyle yakından ilgilidir. Koşul teorisi esas alındığında, önalım hakkının kullanılmasıyla, hakkın yükümlüsü ve sahibi arasında geciktirici koşula bağlı olarak tesis edilmiş olan satış sözleşmesi hukukî etkilerini göstermeye başlar ${ }^{201}$. Başka bir ifadeyle bu ana kadar askıda bulunan satış sözleşmesi etkilerini gösterir ${ }^{202}$. Koşula bağlı olan sözleşme bir borçlandırıcı işlemdir. Dolayısıyla, önalımla ilgili durumlarda BK m 171/III hükmü uygulama alanı bulmaz ${ }^{203}$. Anılan düzenlemeye göre, "koşulun gerçekleşmesinden önce yapılan tasarruflar, koşulun hükümlerini zedelediği oranda geçersiz olur”. Bu düzenlemenin geciktirici koşula bağlı tasarruf işlemleriyle ilgili olarak uygulanacağı belirtilmektedir ${ }^{204}$. Yani çifte koşulun yarattığı bekleme süresi sırasında, pay üzerinde gerçekleştirilecek tasarruf işlemleri ara tasarruf işlemleri olarak nitelendirilip, önalım hakkı içeren sözleşme hükümlerini zedelediği oranda geçersiz kabul edilemeyeceklerdir. Bekleme hali sona erdiğindeyse, yani önalım olayı ve iradi koşul gerçekleştiğinde, önalım hakkı sahibi ve yükümlüsü arasındaki satım sözleşmesinin koşulları etkin hale gelir ${ }^{205}$. Buna karşın kuruluş teorisine göre, taraflar

\footnotetext{
200 Önalım davasında taraf hususuna ilişkin olarak bkz Kizir (n 28) 1773, 1790; Demirbaş (n 28) 249, 271; Eren, Mülkiyet (n 32) 445; Eren, Özel (n 32) 213

201 Bu hususta bkz Forstmoser and Küchler (n 7) 390 para 1246.

202 Bkz Hintz-Bühler (n 4) 102; Germann (n 6) 698 para 1624; Fischer (n 6) 65.

203 Pay devirlerine ilişkin olarak İsviçre hukukunda bu yönde bkz Vischer (n 3) 82, 83.

204 Bu bağlamda bkz Eren, Genel (n 34) 1175. Yine hukukumuzda eski BK bakımından aynı yönde bkz Serozan (n 61) 33. İsviçre hukukunda, öğretinin çoğunluğunun, OR m 152/III düzenlemesinin koşula bağlı tasarruf işlemleri hakkında uygulanacağı, fakat koşula bağlı borçlandırıcı işlemler hakkında uygulanamayacağı Huguenin (n 143) § 14 para 1308'de belirtilmiştir. Yazar aynı yerde şu örneği vermiş̧ir: A ve B geciktirici koşula bağlı bir satım sözleşmesi yaparlar. A, sözleşme konusu şeyi iki gün sonra C'ye satar. C, bu eşyanın maliki olur. B sadece OR m 152/I bağlantısıyla m 97 uyarınca tazminat talep edebilecektir.

${ }^{205}$ Bu hususta bkz Giger (n 28) Art 216 para 157.
} 
arasındaki sui generis sözleşmeye uygun bir şekilde önalım hakkı kullanıldı̆̆ında önalım sözleşmesine konu paylar üzerinde hakkın sahibi ve yükümlüsü arasında bir satış sözleşmesi kurulur.

Satış sözleşmesi çerçevesinde, önalım hakkı sahibi, hakkın yükümlüsünden satım konusunun devrini talep edebilecektir ve buna karşlık da satım bedelinin ödenmesini yükümlenecektir ${ }^{206}$. Önalım hakkının kullanılmasıyla hak sahibi, yükümlünün üçüncü kişiyle yaptığı sözleşmeye dâhil olmaz veya o sözleşmedeki karş1 tarafin yerini almaz ${ }^{207}$. Aksine önalım hakkı sahibiyle yükümlüsü arasında ayrı ve bağımsız bir ilişki söz konusudur ${ }^{208}$. Üçüncü kişiyle yapılmış olan satış ya da ekonomik olarak satışa eşdeğer olan sözleşme de önalım hakkının kullanılması nedeniyle kural olarak ortadan kalkmaz. Ancak hakkın yükümlüsü ile üçüncü kişi, aralarındaki sözleşmede hakkın kullanımıyla o sözleşmenin konusuz kalacağını kararlaştırmış olabilirler ${ }^{209},{ }^{210}$. Dolayısıyla alıcı konumundaki üçüncü kişiye karşı sözleşme ihlalinden kaynaklanan risklerden korunmak önemlidir. Önalım yükümlüsünün üçüncü kişiyle yaptığı sözleşmede, önalım hakkı konusunda bilgilendirme yapması ve sözleşmeyi hakkın kullanılması koşuluna bağlaması bu nedenle tavsiye edilebilir ${ }^{211}$.

Önalım hakkının kullanılması payın devrini gerçekleştirmez. Koşul teorisine göre, etkilerini doğurmaya başlamamış bir satış sözleşmesinin etkilerini doğurmasını sağlar ya da kuruluş teorisine göre, hakkın kullanımıyla taraflar arasında bir satış sözleşmesi kurar. Yani hakkın kullanılması, işlemin borçlandırıcı aşamasını ilgilendirmektedir, tasarruf aşamasını değil. $\mathrm{Bu}$ nedenle sözleşmesel önalım hakkı sahibi, ifa talebini sadece hakkın yükümlüsüne karşı ileri sürebilir. Hakkın yükümlüsünün sözleşme yaptığı üçüncü kişiye karşı hakkı ileri sürmesi mümkün değildir ${ }^{212}$. Sözleşmesel önalım hakkı taraflar arasında hüküm ve sonuçlarını doğurduğundan nisbi etkilidir. Oysa esas sözleşmesel ya da kanunî bağlamın söz konusu olduğu durumlarda farklı sonuçlara ulaşmak mümkündür. Çünkü bunlarda "aynî benzeri" nitelikte mutlak bir etkiden bahsedilmektedir ${ }^{213}$. Sözleşmesel önalım hakkı bakımından, hakkın yükümlüsü, üçüncü kişiye tasarruf işlemini de yerine getirerek payları devrettiyse, üçüncü kişinin o payları kazanması mümkündür ${ }^{214} . \mathrm{Bu}$ durumda önalım hakkının yükümlüsü, hak sahibiyle aralarındaki satış sözleşmesini

\footnotetext{
206 Bkz Fischer (n 6) 65.

207 Bu bağlamda bkz Vischer (n 3) 82, 84.

208 Bu hususta ayrica bkz Forstmoser and Küchler (n 7) 376 para 1181.

209 Bu hususlarda bkz Hintz-Bühler (n 4) 102.

210 "Üçüncü kişinin önalım hakkını sadece biliyor olmasından hareketle, taraflar arasında böyle bir koşulun kararlaştırıldığı sonucuna ulaşılamaz" bkz Vischer (n 3) 82, 84.

211 Bu çerçevede açıklamalar için bkz Forstmoser and Küchler (n 7) 390-391 para 1247.

212 Bu yönde Hintz-Bühler (n 4) 102. Aynı yönde Bahtiyar (n 8) 83, 92-93.

213 Pulaşlı (n 10) 1665 para 163; Tekinalp (n 22) 84.

${ }^{214} \mathrm{Bu}$ hak bir şekilde esas sözleşmeye yazılsa bile, üçüncü kişiyi etkileyecek bir güce kavuşamaz. Öğretimizde belirtildiği üzere, "şahsi bir hakkın üçüncü kişilere dermeyan edilebilmesi için, gayrimenkuller bakımından getirildiği gibi (MK m 735, Eski MK m 658) özel bir yasal düzenlemeye ihtiyaç vardır" [Okutan Nilsson (n 6) 251].
} 
kural olarak yerine getiremeyeceğinden ${ }^{215}$, bu sözleşmeyi ihlal etmiş olur ve bunun sonuçlarına katlanması gerekir ${ }^{216}$. Dolayısıyla, anonim ortaklık payları üzerinde tesis edilen sözleşmesel önalım hakkının, taşınmazlar bakımından tapuya şerh edilmemiş bir önalım hakkına benzediği belirtilebilir. Zira taşınmaz üzerindeki önalım hakkı, tapuya şerh verilmemiş ve başkasına temlik edilmişse, devralan üçüncü kişiye karşı bu hak kullanılamamaktadır. Bu durumda "önalım yükümlüsünden tazminat isteminde bulunma hakkı doğar (MK m 735/I)"217.

\section{Hakkın Üçüncü Kişi Üzerindeki Etkisi}

Sözleşmesel önalım hakkının kullanımı üçüncü kişileri etkilemez. Gerçek önalım hakkına esas sözleşmede yer verilse bile bunun kural olarak tek borç ilkesine aykırı olacağı kabul edilmelidir ${ }^{218}$. Söz konusu hükmün tahvil yoluyla bir sözleşmesel düzenleme olarak değerlendirilmesinin mümkün olabileceği istisnai durumlarda da sözleşmenin nispi etkisi kendini gösterecektir ${ }^{219}$. Dolayısıyla üçüncü kişiye yapılan devir gerçekleştiyse, bu, kural olarak önalım hakkına ilişkin sözleşmenin tarafları arasındaki ${ }^{220}$ olumlu bir sözleşme ihlali teşkil edecektir. Sözleşme ihlalinin borçlar hukukuna özgü olası sonuçları gündeme gelecektir ${ }^{221}$.

Önalım hakkının nispi etkisine rağmen, "esas sözleşmede yer verilmiş" bir "gerçek olmayan" önalım hakkı bakımından farklı sonuçlara ulaşılabilmektedir. Yukarıda gerçek olmayan önalım hakkının esas sözleşmede yer alıp alamayacağının öğretimizde tartışmalı olduğunu belirtmiştik ${ }^{222}$.

Gerçek olmayan önalım hakkının esas sözleşmede yer alması halinde üçüncü kişilerle olan ilişkileri etkileyebileceği hususu uygulamada da farklı yönde kararlara konu olmaktadır. Yargıtay'ın bir kararına göre esas sözleşmede yer verilmiş gerçek olmayan önalım hakkının üçüncü kişiyi etkilemesi mümkündür. Karardan anlaşıldığı kadarıyla, somut olayda ortaklık esas sözleşmesinde, pay devirlerinden önce diğer pay sahiplerine teklifte bulunma zorunluluğu vardır. Pay sahiplerinden birisi buna uymadan paylarını devretmiş ve yönetim kurulu da söz konusu devirleri pay defterine

\footnotetext{
215 Devredenin (yani önalım hakkının yükümlüsünün) aynı paylardan daha fazlasına sahip olması halinde, bu durumun değişiklik gösterme olasıllı̆̆na ilişkin olarak bkz Hintz-Bühler (n 4) 102.

216 Önceki sistemimiz bakımından hukukumuzda, "bu durumda, geriye hak sahibinin yükümlüden yalnızca tazminat talep edebilmesi (Eski BK m 96) olanağı" olduğu belirtilmiştir [bkz Bahtiyar (n 8) 83, 93].

217 Bkz Zevkliler and Gökyayla (n 28) 71. Benzer olarak bkz Yavuz, Acar and Özen (n 8) 256.

218 Mevcut sistemimizde, önalım hakkının esas sözleșme ile tanınıp ticaret siciline tecil edilmiş olmasının dahi durumu değiştirmeyeceği açıkça ifade edilmektedir. "Zira sicilin olumlu etkisi ancak kanunun tescilini ve/veya ilânını öngördüğü hususlar bakımından geçerlidir. Oysa pay üzerinde kurulan önalım hakkı, TTK'da tescili ve/veya ilânı gerekli hususlar arasında sayılmamaktadır" [Bkz Rauf Karasu, Anonim Şirketlerde Emredici Hükümler Illkesi (2th edn, Yetkin Yayınları 2015) 204]

219 Bu hususta bkz III, C, 2 altındaki açıklamalar.

$220 \mathrm{Bu}$ esas taşınmazlar bakımından da kabul edilmekle birlikte taşınmazlarda tapu siciline yapılacak şerhin bu noktada farklılık yarattığ ifade edilmektedir [bu hususta Demirbaş (n 28) 249, 252].

221 Karş Tekinalp (n 9) 608-609 para 862-863.

222 Bkz yukarıda III, C, 1.
} 
işlemiştir. Buna karşı dava açılmış ve pay devrinin iptali ve pay defterindeki kaydın terkini talep edilmiştir. Bunun üzerine yerel mahkeme davayı reddetmiş, daire yerel mahkeme kararını onamış ve karar düzeltme talebi de yerel mahkeme ve dairenin gerekçesi tekrar edilerek şu şekilde reddedilmiştir: "Mahkemece, devirlerin geçerli olması için esas sözleşme hükmüne göre pay devrinin öncelikle şirket ortaklarına teklif edilmesi gerektiği, bu hususun davalı tarafça ispat edilmesi gerektiği, dosya kapsamından davacıya teklif yapıldığına dair delil ibraz edilmediği, bu sebeple devrin geçersiz olduğu, ancak esas sözleşmede ve kanunda önalım hakkının nasıl kullanılacağ 1 düzenlenmediği, şuf’a davasının kıyasen uygulanabileceği, davada, davacı adına devir yapılmasının talep edilmediği, sadece geçersizliği ileri sürmesi satın almam-sattırmam gibi bir durum doğuracağı, MK'nın 2. maddesi anlamında hakkın kötüye kullanımı olacağı gerekçesi ile ...'ın açmış olduğu davanın feragat nedeni ile reddine, davacı ... ' 1 açtığı davanın reddine dair verilen karar davacı ... ... vekili tarafından temyizi üzerine Dairemizin 18/11/2013 tarihli kararı ile onanmıştır”223. $\mathrm{Bu}$ durumda esas sözleşmeyle kabul edilmiş gerçek olmayan bir önalım hakkına aykırılık nedeniyle Yargıtay devrin geçersizliğini kabul etmiştir. Yani Yargıtay bu tür esas sözleşme hükümlerine aykırı devirlerin üçüncü kişileri etkileyebileceğini anılan kararında kabul etmektedir. Ancak bu geçersizliğin somut olaydaki öne sürülme şekli MK m 2'ye aykırı bulunmuştur.

Yargıtay'ın, gerçek olmayan önalım hakkına ilişkin başka bir kararında, farklı yönde bir sonuca ulaştığı anlaşılmaktadır. Karşı oy da içeren kararda Yargıtay, yerel mahkemenin farklı yöndeki kararını onamıştır. Karara göre, “... esas mukavelenin 9. maddesi uyarınca payını devretmek isteyen paydaşın devretmek istediği payları yönetim kurulu aracıllı̆ııla şirketin diğer paydaşlarına gerçek değeri üzerinden teklif etme zorunluluğu getirdiği, ancak bu zorunluluğun bir teklif yükümü getirip, teklif yapılmamasının devir işlemlerinin geçersizliği sonucunu doğurmayacağı, zira maddenin devamında yönetim kurulunun bu düzenlemeye aykırı devirleri kabul etmek zorunda olmadığını belirtmesi suretiyle, bu şekilde yapılan devirlerin kabul edilebileceğinin de anlaşıldığını, ayrıca devre dair yasal şartların da gerçekleştiği gerekçesiyle davanın reddine karar verilmiştir"’24. Yine Eski TTK döneminde verdiği başka bir kararında Yargitay benzer yönde ve daha açık olarak nispilik yönünde karar vermiştir ${ }^{225}$.

Kanaatimizce somut olay değerlendirilirken, öncelikle söz konusu düzenlemenin esas sözleşmede yer alıp almadığı ortaya konmalıdır. Esas sözleşmede yer almıyor ve

\footnotetext{
223 Yargıtay 11 HD, 8324/13581, 11.9.2014 (karar için bkz Kazancı - İçtihat Bilgi Bankası <http://www.kazanci.com> Erişim Tarihi 11 Haziran 2018).

224 Yargıtay 11 HD, 11944/5634, 24.5.2016 (karar için bkz Kazancl - İçtihat Bilgi Bankası <http://www.kazanci.com> Erişim Tarihi 10 Haziran 2018).

225 Yargıtay 11 HD, 7138/1522, 23.2.1995, kararına göre, “....anasözleșmede yer alan ve bir nevi önalım hakkı benzeri olan bu hükmün satışın gerçekleşmesi halinde sözleşmede yer alan prosedürün yerine getirilmemiş veya eksik bırakılmış olması halinde pay senetlerini devir alan üçüncü kişilere karşı ileri sürülmesinin mümkün olmadığının kabulü gerekecektir" [karar için Moroğlu (n 67) 515, 525-529; Tekinalp (n 9) 608, para 861].
} 
doğrudan ayrı bir pay sahipleri sözleşmesinden bahsediliyorsa zaten bu sözleşmenin üçüncü kişiyi etkileyebilmesi olanağ yoktur. Esas sözleşmede yer alan bir düzenleme varsa, bunun gerçek önalım hakkı mı, yoksa gerçek olmayan önalım hakkı mı teşkil ettiği değerlendirilmelidir. Pay sahiplerini birbirine karşı yükümlendiren gerçek bir önalım hakkı hem bir esas sözleşmenin düzenleme alanını oluşturmamakta hem de tek borç ve payların serbest devredilebilirliği ilkelerini ihlâl etmektedir. Dolayısıyla bu düzenlemelerin esas sözleşmelerde yer alması düşünülemez ve bir şekilde yer alırsa da kural olarak kesin hükümsüz olduğu kabul edilmelidir. Ancak bunun tahvil yoluyla ayakta tutulabileceği bir durum söz konusuysa, düzenleme en iyi olasılıkla taraflar arasında bir pay sahipleri sözleşmesi olarak değerlendirilebilir. Bu durumda yine üçüncü kişinin söz konusu düzenlemeden etkilenmesi mümkün değildir. Gerçek olmayan bir önalım hakkının esas sözleşmede yer alıp alamayacağı hususuysa, öğreti ve uygulamamız nezdinde tartışmalıdır. Bu nedenle kabul edilecek görüşe göre, farklı sonuçlara ulaşmak mümkündür. Dolayısıyla öncelikle somut düzenlemenin payların serbest devredilebilirliği, emredici hükümler ilkesi ve tek borç ilkelerinin yanı sıra özellikle TTK'nın bağlam sistemine ilişkin esasları karşısındaki durumu değerlendirilmelidir. Bu çerçevede hükmün esas sözleşme hükmü olarak geçerli olup olmadığına karar verilmelidir. Eğer hükmün esas sözleşme hükmü olarak geçerli olduğu kanaatine ulaşılırsa ancak o zaman gerçek olmayan önalım hakkına aykırıllğın üçüncü kişiyi etkileyebileceği hususu gündeme gelecektir. Aksi takdirde üçüncü kişilerin söz konusu düzenlemeden etkilenmeyecekleri kabul edilecektir.

\section{Hakkın Sona Ermesi}

Önalım hakkı kural olarak kullanılmakla birlikte sona erer $^{226}$. Önalım hakkını kullanarak payları kazanan hak sahibi daha sonra payı başka kişilere devredebilirir27. Çünkü bunlar kullanmakla tükenen haklardır ${ }^{228}$. Ancak bu durum özellikle adi ortaklık niteliği taşıyan pay sahipleri sözleşmelerine uymamaktadır. Çünkü payı önalım hakkı kullanmak suretiyle kazanan ya da kazananlar hali hazırda bir pay sahipleri sözleşmesine taraf olmaya devam etmektedirler. Bu nedenle, sözleşmede, önalım hakkının sadece o andaki payları değil, ileride edinilecek payları da kapsayacağının kararlaştırılmasında fayda olduğu öğretide belirtilmektedir ${ }^{229}$. Önalım hakkı, pay sahibinin sahip olduğu tüm payları üzerinde tesis edilmişse, bunun sahip olduğu veya olacağı tüm payları kapsadığının açıkça belirtilmesi olası uyuşmazlıkları engeller. Pay sahipleri sözleşmesi dışında birisi payı kazanmışsa, onun pay sahipleri sözleşmesine dâhil olması, ancak satım sözleşmesinde buna yönelik bir yükümlülük kararlaştırılmasıyla mümkündür. Aksi halde o paylarla ilgili sözleşmesel önalım

\footnotetext{
226 Hintz-Bühler (n 4) 105.

227 Bu bağlamda bkz Forstmoser and Küchler (n 7) 392 para 1251.

228 Bkz Germann (n 6) 708 para 1652.

229 ibid 708 para 1652; Hintz-Bühler (n 4) 105-106.
} 
hakk1 sona erecektir ${ }^{230}$. Bu durum öğretide tam üçüncü kişi lehine bir sözleşme olarak nitelenmektedir. Zira pay sahipleri sözleşmesinde kalan taraflara payı devralan kişinin katılımını kabul edip etmeme olanağı verilmektedir ${ }^{231}$.

Sözleşmesel önalım hakkının süresi içinde kullanılmaması hakkın düşümüne neden olur. Hak sözleşmedeki süre ya da bu hususta bir anlaşma yoksa kıyasen uygulanan BK m 242'deki üç aylık süre içinde kullanılmalıdır. Sözleşmesel önalım hakkının süresi içinde kullanılmamasıyla ilgili olarak bir hususa özellikle dikkat çekmek istiyoruz. Hak düşümü sadece somut olaydaki önalım olayı bakımından mümkündür ${ }^{232}$. Somut olayda önalım hakkının kullanımını doğuracak bir işlem gerçekleşmiş ve bu usulüne göre bildirilmişse, hak süresi içinde kullanılmalıdır. Hak süresi içinde kullanılmamış, fakat yapılan işlem de sonuçlandırılıp devir gerçekleştirilmemişse, hak yeni yapılacak borçlandırıcı işlemler bakımından yine kullanılabilir olacaktır. Yani başka bir kişiyle önalım kapsamında bir işlem yapılırsa, yeni işlem bakımından önalım hakkı kullanılabilir.

Önalım hakkı içinde bulunduğu sözleşmenin sona ermesiyle de sona erecektir. Özel bir düzenleme olmadığı sürece, önalım hakkı genel olarak pay sahipleri sözleşmesiyle aynı kaderi paylaşır ve her durumda bununla birlikte sona $\operatorname{erer}^{233}$. Taraflar sözleşmede önalım hakkı için bir süre öngörebilirler. Bu, yukarıda bahsedilen hakkın kullanımına ilişkin hak düşürücü süreden farklıdır. Sözleşmede bu yönde bir süre öngörülmüşse, hak süreyle birlikte sona erer $^{234}$.

Önalım olayını gerçekleştirmeyecek bir pay devri söz konusu olursa, önalım hakk1 da sona erer. Örneğin, önalım kapsamında olmayacak bir bağışlama ya da payların bir ortakllğa sermaye olarak getirilmesi gibi durumlarda devir gerçekleşmekte, fakat önalım kapsamında bir işlem yapılmamaktadır. Bu durumda da ilgili paylar bakımından önalım hakkı sona ermiş olur. Tabi ki külli halefiyet gerektiren devirlerin bundan ayrı olduğunu da belirtmek gerekir ${ }^{235}$. Ayrıca önkoşulu gerçekleştirmeyecek bir pay devri söz konusu olsa da, payı bu şekilde devralan kişinin sözleşmesel olarak hakkın devraldığı paylar üzerinde devam edeceğini kabul etmesi de mümkündür ${ }^{236}$.

Önalım hakkı aktarılan durumlar dışında, çeşitli sebeplerle de sona erebilir. Tarafların bu yönde bir anlaşması hakkı sona erdirir. Bu durumda BK m 132'nin uygulama alanı bulacağı belirtilebilir. Yani önalım hakkı öngören sözleşmenin tarafları bu sözleşmeyi iradi olarak da olsa bir şekle bağlamışlarsa, bu şekil

\footnotetext{
230 Bkz Germann (n 6) 709 para 1652.

231 Bu anlama gelmek üzere bkz Forstmoser and Küchler (n 7) 392 para 1252.

232 Bu bağlamda bkz ibid 393 para 1254. Ayrıca bkz Germann (n 6) 709 para 1653.

233 Açıklamalar için bkz Forstmoser and Küchler (n 7) 393 para 1256.

234 Bkz Germann (n 6) 709 para 1654; Hintz-Bühler (n 4) 107.

235 Bu hususta bkz Forstmoser and Küchler (n 7) 393 para 1258.

236 Bu hususlara ilişkin olarak ayrıca bkz Hintz-Bühler (n 4) 108.
} 
olmaksızın yaptıkları bir ibra sözleşmesi hakkı sona erdirici etkide olacaktır. Tabi ki çok taraflı ve özellikle adi ortaklık teşkil eden pay sahipleri sözleşmeleri açısından, kural olarak tüm sözleşme taraflarının onayının gerekeceği belirtilmelidir ${ }^{237}$. Payları önalım hakkına yönelik sözleşmeye konu olan anonim ortaklığın tasfiye edilip ortadan kalkması gibi somut olaya özgü farklı birçok neden de önalım hakkının sona ermesini sağlayabiliir ${ }^{238}$.

\section{Sonuç}

Pay sahipleri sözleşmelerinde önalım hakkı düzenlemesi yapılmasının birçok gerekçesi vardır. Sözleşmesel önalım hakkı, belli bir pay sahipleri çevresinin kontrol altında tutulmasını sağlamak amacıyla öngörülür. Anonim ortaklıklar hukukuna özgü bağlam sistemine benzer amaçları gütmektedir.

Pay sahipleri sözleşmesinde kararlaştırılan önalım hakkı kural olarak bir şekle tabi değildir. Ölüme bağlı bir önalım hakkı tanınması halinde sözleşme bir bütün olarak değerlendirilmelidir. Adi ortaklık niteliği taşıyan pay sahipleri sözleşmelerinde durum ikiye ayrılarak incelenmelidir. Eğer önalım hakkı nitelikli halefiyet klozu ile birlikte yer alıyorsa bunun ölüme bağlı tasarrufların şekline tabi olması gerekir. Basit halefiyet klozuyla adi ortaklık niteliği taşımayan sözleşmeler bakımından önalım hakkının ölüme bağlı tasarrufların şekline tabi olmasına gerek yoktur.

Pay sahipleri arasındaki gerçek önalım hakkı ancak sözleşmesel düzeyde incelenebilir. Yoksa esas sözleşmelerde gerçek önalım hakkına yer verilmesi mümkün olmamalıdır. Bir şekilde esas sözleşmede yer alan gerçek önalım hakkının pay sahipleri sözleşmesi olarak değerlendirilebilmesi istisnai bir olasılıktır. Geçersiz bir esas sözleşme hükmünün tahvil yoluyla borçlar hukuku sözleşmesi olarak dikkate alınması tamamen olanaksız değildir. İstisnaen tüm kurucu pay sahiplerinin açık bir şekilde önalım hakkını kabul ettikleri küçük ortaklıklarda tahvil yoluyla geçersiz olan esas sözleşme hükmünün pay sahipleri arasında bir sözleşme olarak dikkate alınması olanaklıdır. Ancak bunun için de bazı koşullar aranması gerektiği sonucuna ulaşılmıştır.

Ön alım hakkı içeren sözleşmeler bakımından sözleşmenin zorunlu içeriği, sözleşme tarafları (ön alım hakkı sahibi ve yükümlüsü) ile sözleşme konusudur. Bedel hususunda BK m 241/III düzenlemesi kıyasen uygulama alanı bulabilmelidir. Başka bir ifadeyle sözleşmede herhangi bir düzenleme yapılmadıysa, bedel ödeme borcu, devredenin üçüncü kişiyle yaptı̆̆ sözleşmedeki bedele göre tespit edilecektir. Bu nedenle sınırlandırılmamış ve sınırlandırılmış önalım hakkı ayrımı paylar üzerinde tesis edilen sözleşmesel önalım hakkı bakımından da yapılmıştır.

\footnotetext{
237 Bu hususta bkz Germann (n 6) 710 para 1656; Hintz-Bühler (n 4) 108.

238 Bu bağlamda bkz Forstmoser and Küchler (n 7) 393 para 1258.
} 
Önalım hakkının kullanılmasının önkoşulu önalım olayı olarak adlandırılmaktadır. Önalım olayına ilişkin BK m 240/I'in kıyasen uygulanabileceği sonucuna ulaşılmışıtır. Özellikle BK m 241/II ve iptal edilebilir işlemler de çalışmada değerlendirilmiştir. Bunun dışında örneğin bağlamlı paylarda ortaklığın devre onay vermemesi halinde kullanılmış olan önalım hakkının akıbeti, bağlamın hukuki niteliği çerçevesinde değerlendirilmiştir.

Önalım olayının gerçekleştiğini bildirme yükümlülüğü vardır. Bunun BK m 241 'deki şekle uygun olarak yapılmasına gerek yoktur. Yine BK m 241'den farklı olarak önalım olayının gerçekleştiğini bildirme yükümlülüğü satıcı bakımından kabul edilmiş, fakat alıcı üçüncü kişinin böyle bir yükümlülük altında olmadı̆̆ 1 savunulmuştur. Önalım olayının gerçekleşmesinin engellenmesi durumunda değişik ihtimallerin yanında BK m 175 düzenlemesinin de uygulanabileceği sonucuna ulaşılmıştır.

Önalım hakk1, hakkın konusu bölünmeksizin kullanılabilir. Konunun bölünememesi ilkesinin hakkın kullanımı üzerinde doğrudan doğruya etkileri vardır. Bu etkiler değerlendirilmiştir. Hakkın kullanımı bakımından bir süre olması gerektiği, bunun başlangıcı ve uzunluğu belirtilmiştir. Fakat BK m 242'de öngörülen iki yıllık sürenin pay üzerinde öngörülen sözleşmesel önalım hakları bakımından uygulanamayacağ1 sonucuna ulaşılmıştır.

Önalım hakkını kullanmanın etkisi kural olarak taraflar arasındadır. Sonuçları hakkın hukuki niteliğinde kabul edilen koşul ya da kuruluş teorilerine göre farklılık gösterebilmektedir. Ön alım hakkının kullanılmasıyla hak sahibi, yükümlünün üçüncü kişiyle yaptığı sözleşmeye dâhil olmaz veya o sözleşmedeki karşı tarafın yerini almaz. Ön alım hakkının kullanılması payın devrini gerçekleştirmez.

Önalım hakkının üçüncü kişi üzerinde kural olarak etkisi olmamasına rağmen istisnaen oluşabilecek vakıalar dikkate alınmıştır. Bunun haricinde, hakkın sona ermesini gerektirecek nedenler ve bunun etkileri ayrıca değerlendirilmiştir.

Finansal Destek: Yazar bu çalışma için finansal destek almamıştır. 


\section{Kısaltmalar Cetveli/List of Abbreviations}

AG: $\quad$ Die Aktiengesellschaft

AJP: $\quad$ Aktuelle juristische Praxis

Art: $\quad$ Artikel

AÜHFD: $\quad$ Ankara Üniversitesi Hukuk Fakültesi Dergisi

Batider: $\quad$ Banka ve Ticaret Hukuku Dergisi

BGB: Bürgerliches Gesetzbuch

BGE: $\quad$ Entscheidungen des Schweizerischen Bundesgerichtes

bkz: bakınız

BK: $\quad 6098$ sayılı Türk Borçlar Kanunu

Eski BK: $\quad 818$ sayılı Borçlar Kanunu

Eski TTK: 6762 sayılı Türk Ticaret Kanunu

EÜHFD: $\quad$ Erzincan Üniversitesi Hukuk Fakültesi Dergisi

GesKR: $\quad$ Schweizerische Zeitschrift für Gesellschafts- und Kapitalmarktrecht sowie Umstrukturierungen

GmbH: Die Gesellschaft mit beschränkter Haftung

HD: $\quad$ Hukuk Dairesi

HGK: Hukuk Genel Kurulu

İÜHFM: İstanbul Hukuk Mecmuas1

karş: $\quad$ karşıllaştırınız

m: $\quad$ madde

MK: $\quad 4721$ sayılı Türk Medeni Kanunu

OR: Obligationenrecht

REPRAX: ZeitschriftzurRechtsetzung und Praxis im Gesellschafts-und Handelsregisterrecht

SchlT AG: Schlussbestimmungen des Bundesgesetzes über die Revision des Aktienrechts vom 4. Oktober 1991

SJZ: $\quad$ Schweizerische Juristen Zeitung

ST: Der Schweizer Treuhänder

TBK: $\quad 6098$ sayılı Türk Borçlar Kanunu

TMK: $\quad 4721$ sayılı Türk Medeni Kanunu

TREX: Der Treuhandexperte

TTK: $\quad 6102$ sayılı Türk Ticaret Kanunu

vd: $\quad$ ve devamı

ÜBest: $\quad$ Übergangsbestimmung(en)

YÜHFD: $\quad$ Yeditepe Üniversitesi Hukuk Fakültesi Dergisi 


\section{Bibliyografya/Bibliography}

Akın MY, Anonim Ortaklıkta Bağlı Nama Yazılı Hisseler (Vedat 2014)

Aydoğdu M and Kahveci N, Türk Borçlar Hukuku-Özel Borç Illişkileri (Sözleşmeler Hukuku) (Adalet 2017)

Bahtiyar M, 'Anonim Ortaklıkta Payların Üçüncü Kişilere Satılması Durumunda Diğer Ortaklara Önalım Hakkı Tanıyan Anasözleşme Hükümleri ve Etkileri’ (2001) 21 (2) BATİDER 83-126

Baumann MR, Die Familienholding (Schulthess 2016)

Bozkurt T, Anonim Şirketlerde Pay Devrinin Sinırlandırılması (Bağlam) -Die Vinkulierung- (On İki Levha 2016)

Böckli P, Schweizer Aktienrecht (Schultess 2009)

Bösiger M, 'Bedeutung und Grenzen des Aktionärbindungsvertrages bei personenbezogenen Aktiengesellschaften' (2013) (1) REPRAX 1-17

Buz V, Medeni Hukukta Yenilik Doğuran Haklar (Yetkin 2005)

Bühler S, OTC-Handel mit nichtkotierten Aktien (Schulthess 2016)

Demirbaş F, 'Sözleşmeden Doğan Önalım Hakkı' (2016) 65 (2) AÜHFD 249-277

Eren F, Borçlar Hukuku Genel Hükümler (Yetkin 2015) [Genel]

Eren F, Borçlar Hukuku Özel Hükümler (Yetkin 2017) [Özel]

Eren F, Mülkiyet Hukuku (Yetkin 2011) [Mülkiyet]

Feyzioğlu FN, 'Şuf'a Hakkının Kullanılması Mümkün Olan ve Olmayan Tasarruflar' (1953) 19 (1-2) İ̈̈HFM 222-269 [Hakkın Kullanılması]

Feyzioğlu FN, 'Şuf'a Hakkının Mevzuu ve Süjeleri' (1952) 18 (3-4) İ̈HHFM 875-902

Feyzioğlu FN, Şuf'a Hakkı (Fakülteler Matbaası 1959)

Fischer D, Änderungen im Vertragsparteienbestand von Aktionärbindungsverträgen (Dike 2009)

Forstmoser P and Küchler M, Aktionärbindungsverträge Rechtliche Grundlagen und Umsetzung in der Praxis (Schulthess 2015)

Furer A, Schnyder AK and Roth Pellanda K (eds), Obligationenrecht - Allgemeine Bestimmungen, (Art. 1-183 OR), CHK-Handkommentar zum Schweizer Privatrecht (Schulthess 2016)

Germann S, Die personalistische AG und GmbH - Unter besonderer Berücksichtigung von Aktionär- und Gesellschafterbindungsverträgen (Dike 2015)

Giger H, Berner Kommentar zum schweizerischen Privatrecht, Der Grundstückkauf, Art. 216-221 $O R$, vol VI/2/1/3 (Heinz Hausheer ed Stämpfli 1997)

Gloor M and Flury AE, 'Die Call Option an Aktien beim Tod eines Aktionärs' (2005) 101 (13) SJZ 305-313

Guhl T and others, Das Schweizerische Obligationenrecht mit Einschluss des Haldels- und Wertpapierrechts (Schulthess 2000)

Gümüş MA, ‘6098 Sayılı Türk Borçlar Kanunu’nun Akdi Önalım Hakkına İlişkin Hükümlerinin (TBK m. 237/III, 238, 239 ve 240-242) Değerlendirilmesi’ (2011-2012) 8-9 (2-1) YÜHFD (Prof. Dr. Erhan Adal'a Armağan) 435-453

Haab D, 'Der Aktionärbindungsvertrag - Vereinbarung zur Ergänzung des Aktienrechts und Mittel für eine massgeschneiderte Nachfolgeregelung' (2007) (5) ST 383-386

Hintz-Bühler M, Aktionärbindungsverträge (Stämpfli 2001)

Honsell H, Vogt NP and Watter R (eds), Basler Kommentar, Obligationenrecht II, Art. 530-964 OR, Art. 1-6 SchlT AG, Art. 1-11 ÜBest GmbH, vol 2 (Helbing Lichtenhahn 2012) 
Honsell H, Vogt NP and Wiegand W (eds), Basler Kommentar, Obligationenrecht I, Art. 1-529 OR, vol 1 (Helbing Lichtenhahn 2011)

Huguenin C, Obligationenrecht - Algemeiner und Besonderer Teil (Schulthess 2012)

Karasu R, Anonim Şirketlerde Emredici Hükümler İlkesi (2th edn, Yetkin Yayınları 2015)

Kılıçoğlu A, Borçlar Hukuku Genel Hükümler (17th edn, Turhan 2013)

Kizir M, '6098 Sayılı Türk Borçlar Kanununa Göre Satış İlişkisi Doğuran Haklar ve Özellikle Önalım Hakkına İlişkin Hükümlerin Değerlendirilmesi’ (2016) 22 (3) MÜHF-HAD (Prof. Dr. Cevdet Yavuz'a Armağan, vol 2) 1773-1796

Kläy H, Die Vinkulierung (Helbing \& Lichtenhahn 1997)

Kostkiewicz JK and others (eds), OR Kommentar - Schweizersiches Obligationenrecht (3rd edn Orell Füssli 2016)

Matt I, Der bedingte Vertrag im schweizerischen und liechtensteinischen Privatrecht (Schulthess 2014)

Meier Hayoz A and Doğanay Ü (trs), ‘Şuf’A Akdi’ (1967) 33 (3-4) İ̈HHFM 273-287

Meyer M, 'Vinkulierte Aktien in der Zwangsverwertung' (1997) 93 SJZ 22-26

Moroğlu E, ‘Anonim Ortaklık Anasözleşmesi ve Hukuki Niteliği’ Prof. Dr. M. Kemal Oğuzman’ın Anısina Armağan (Beta 2000) 515-529

Müller R and Biedermann K, 'Der Aktionärbindungsvertrag als Unterstützungsmassnahme bei der Nachfolge- und Nachlassregelung' (2015) (6) AJP 885-895

Müller-Chen M and Huguenin C (eds), Vertragsverhältnisse Teil 1: Innominatkontrakte, Kauf, Tausch, Schenkung, Miete, Leihe (Art. 184 - 318 OR), CHK - Handkommentar zum Schweizer Privatrecht (Schulthess 2016)

Narbay Ş, ‘6102 Sayılı Yeni Türk Ticaret Kanunu'na Göre Anonim Ortaklıkta Pay ve Pay Senetlerinin Devri’ (2012) XVI (3-4) EÜHFD 201-251

Narbay Ş, Anonim Ortaklıkta Pay Defteri (Seçkin 2003) [Pay Defteri]

Okutan Nilsson G, Anonim Ortaklıklarda Paysahipleri Sözleşmeleri (Çağa Hukuk Vakfi 2004)

Poroy R, Tekinalp Ü and Çamoğlu E, Ortaklıklar Hukuku, vol 1 (Vedat 2014)

Pulaşlı H, Şirketler Hukuku Şerhi, vol 2 (Adalet Yayınevi 2014)

Rüegg J, Rechtsgeschäftliche Vorkaufsrechte an Grundstücken (Jörg Schmid ed Schulthess 2014)

Rütter J and Zwyssig K, ‘Aktionärbindungsverträge’ (2010) (3) TREX 142-144

Serozan R, Sağlararası İşlem Yoluyla Ölüme Bağlı Kazandırma (Fakülteler Matbaası 1979)

Tekinalp Ü, Anonim Ortaklıkta Yeni Bağlam Sisteminin Esasları (Vedat 2012)

Uzel N, 6102 sayll Türk Ticaret Kanunu ve 6362 sayılı Sermaye Piyasası Kanununa Göre Anonim Ortaklıkta Esas Sözleşmesel Bağlam (On İki Levha 2013)

Vischer M, 'Vorkaufsrechte an Aktien' (2014) (1) GesKR 82-88

von der Crone HC, Aktienrecht (Stämpfli 2014)

Yavuz C, Acar F and Özen B, Türk Borçlar Hukuku Özel Hükümler (Beta 2014)

Zevkliler A and Gökyayla E, Borçlar Hukuku - Özel Borç İlişkileri (Turhan 2013)

Zobl D, 'Die Pfandrechtliche Sicherung von Erwerbsberechtigungen in Aktionärbindungsverträgen' in Hans Caspar von der Crone and others (eds), Neuere Tendenzen im Gesellschaftsrecht Festschrift für Peter Forstmoser (Schulthess 2013) 401-413 